ORIGINALMENTE PUBLICADO EM: SIEBER, ULRICH. GRENZEN DES STRAFRECHTS - GRUNDLAGEN UND HERAUSFORDERUNGEN DES NEUEN STRAFRECHTLICHEN FORSCHUNGSPROGRAMMS AM MAX-PLANCK-INSTITUT FÜR AUSLÄNDISCHES UND INTERNATIONALES STRAFRECHT, ZEITSCHRIFT FÜR DIE GESAMTEN STRAFRECHTSWISSENSCHAFTEN, BAND 119 (2007), S. 1-68.

\title{
LIMITES DO DIREITO PENAL * PRINCÍPIOS E DESAFIOS DO NOVO PROGRAMA DE PESQUISA EM DIREITO PENAL NO INSTITUTO MAX-PLANCK DE DIREITO PENAL ESTRANGEIRO E INTERNACIONAL
}

Ulrich Sieber

THE LIMITS OF CRIMINAL LAW

tradução Alessandro Hirata ReVISÃo da tradução Vivian C. Schorscher REVISÃo técnica Vivian C. Schorscher, Marta R. A. Machado, Flávia P. Püschel

\section{RESUMO}

ESTE TEXTO CONTÉM O PROGRAMA DE PESQUISA QUE IRÁ ORIENTAR AS atividades do Instituto MaX-Planck de DiReito Penal ESTRANGEIRO E INTERNACIONAL DE FRIBURGO NOS ANOS QUE SEGUEM. O PROGRAMA FUNDA-SE NUM DIAGNÓSTICO ABRANGENTE DOS PRINCIPAIS PROBLEMAS PENAIS ENFRENTADOS PELO DIREITO NO MUNDO DE HOJE E, POR ESTA RAZÃO, ALÉM DE NORTE PARA UM DOS PRINCIPAIS CENTROS DE PESQUISA EM DIREITO PENAL NO MUNDO, O TEXTO É UM MAPA PRECISO DAS MAIS RELEVANTES QUESTÕES PENAIS CONTEMPORÂNEAS. ELE TEM TRÊS OBJETIVOS PRINCIPAIS: (A) ANALISAR ALTERAÇÕES NOS RISCOS À SEGURANÇA E AS IDÉIAS SOBRE SEGURANCA NUMA SOCIEDADE MARCADA PELA GLOBALIZACÃO E POR MUDANÇAS TÉCNICAS E ECONÔMICAS; (B) ANALISAR A CRITICAR AS ALTERAÇŌES LEGAIS QUE ACOMPANHAM AS MUDANCTAS MENCIONADAS E SUAS CAUSAS, (III) DESENVOLVER NOVAS RESPOSTAS PARA OS DESAFIOS POSTOS PELA NECESSIDADE DE EFETIVAR AS LEIS. TRÊS ASSUNTOS MERECEM MAIOR DESTAQUE: O CRIME ORGANIZADO INTERNACIONAL, O TERRORISMO E OS CRIMES COMETIDOS PELA INTERNET.

\section{PALAVRAS-CHAVE}

Instituto Max-Planck de Direito Penal estrangeiro E INTERNACIONAL; RISCOS DE SEGURANÇA; GLOBALIZAÇÃO E TRANSFORMAÇÃO TÉCNICA, ECONÔMICA E POLÍTICA; DESAFIOS POLÍTICO-CRIMINAIS; CRIMINALIDADE ORGANIZADA; TERRORISMO; INTERNET

\begin{abstract}
THIS PAPER DESCRIBES THE RESEARCH PROGRAM IMPLEMENTED BY THE CURRENT DIRECTOR OF THE MAXPLANCK-INSTITUTE FOR FOREIGN AND INTERNATIONAL PENAL LAW, WHICH HAS ITS FOCUS DIRECTED TO THE CURRENT CHALLENGES POSED TO PENAL LAW BY CONTEMPORARY SOCIAL, ECONOMIC AND POLITICAL CHANGES. THIS PROGRAM HAS THREE GOALS: (I) TO ANALYZE THE REAL ALTERATIONS TO SECURITY RISKS AND THE IDEAS REGARDING SECURITY IN A SOCIETY BRANDED BY GLOBALIZATION AND TECHNICAL, ECONOMIC AND POLITICAL CHANGES; (II) TO ANALYZE AND CRITICALLY EVALUATE THE LEGAL CHANGES THAT ACCOMPANY SAID CHANGES AND THEIR CAUSES; (III) THE DEVELOPMENT OF NEW ANSWERS TO THE CHALLENGES POSED TO LAW ENFORCEMENT POLICIES. IN THIS CONTEXT, THE FOLLOWING ASPECTS ARE HIGHLIGHTED: INTERNATIONAL ORGANIZED CRIMINALITY, TERRORISM AND CRIMES COMMITTED OVER THE INTERNET.

\section{KEYWORDS}

MAX-PLANCK-INSTITUTE FOR FOREIGN AND INTERNATIONAL PENAL LAW, SECURITY RISKS, GLOBALIZATION AND TECHNICAL, ECONOMIC AND POLITICAL CHANGES, CHALLENGES TO LAW ENFORCEMENT POLICIES, ORGANIZED CRIMINALITY, TERRORISM, INTERNET
\end{abstract}

\section{INTRODUÇÃO}

A sucessão na diretoria do Instituto Max-Planck de direito penal estrangeiro e internacional de Friburgo, no final de 2003, motivou a concepção de um "programa de pesquisa” projetado a longo prazo na divisão de direito penal do instituto. Tal programa ${ }^{1}$ 
- apresentado em forma de discurso de posse na comemoração da sucessão do cargo em março de 2004 - deverá concentrar os futuros trabalhos nos problemas centrais do direito penal do futuro, obter sinergia entre os projetos de pesquisas individuais e desenvolver novas abordagens para soluções no contexto de uma construção teórica de grande alcance. ${ }^{2}$

O "objeto do novo programa de pesquisa" são os desafios atuais do direito penal, derivados de modificações sociais, econômicas e políticas. Essas modificações sociais ocorrem em alta velocidade na atual sociedade mundial, de informação e de risco. Elas têm efeitos graves no desenvolvimento da criminalidade, no direito penal e na política criminal, podendo - como o princípio da prevenção, que avança no direito penal - conduzir a uma mudança de paradigmas. Esta mudança faz-se presente por meio da criação de novas formas de cooperação internacional e do direito penal supranacional não apenas no direito penal europeu e no direito penal internacional. Mudanças ainda mais graves revelam-se nas ações contra o terrorismo, por meio da dissolução de categorias políticas e jurídicas clássicas, como a distinção entre segurança interna e externa, guerra e crime, serviços secretos e polícia, polícia e milícia, assim como guerra e paz. ${ }^{3}$

Diante do pano de fundo desse desenvolvimento, o novo programa de pesquisa do Instituto Max-Planck de direito penal estrangeiro e internacional tem três "objetivos de pesquisas", cada qual constituindo a base para o seguinte; são eles: (i) a análise das "modificações reais" dos riscos de segurança e dos pensamentos sobre segurança na sociedade marcada pela globalização e pela transformação técnica, econômica e política; (ii) a análise e avaliação crítica das "modificações normativas" que acompanham referidas transformações e suas causas, assim como (iii) o desenvolvimento de novas respostas para os relevantes desafios "político-criminais".

A orientação do programa de pesquisa para as modificações sociais e jurídicas exige, para a determinação dos futuros “pontos centrais da pesquisa”, primeiramente, uma análise da modificação social, seus efeitos sobre a criminalidade, o direito penal e a política criminal, assim como das questões fundamentais dela resultantes. ${ }^{4}$ Esta análise estará no centro das observações que seguem (2.). Por fim, serão expostos os métodos e projetos de pesquisa com os quais esse programa de pesquisa deverá ser implementado (3.).

\section{Modificações atuais da SOCIEDAde, DA CRIMINAlidAde, DO DIREITO PENAL E DA POLÍTICA CRIMINAL: DOS DESAFIOS CATEGORIAIS DO DIREITO PENAL NA SOCIEDADE GLOBAL DE RISCO}

As atuais mudanças sociais podem ser descritas de maneira emblemática com a expressão "sociedade global de risco". 5 Por trás desse conceito, estão os desenvolvimentos da "sociedade mundial", da "sociedade de informação" e da "sociedade de 
risco", estreitamente entrelaçadas. A partir dessas modificações, são especialmente relevantes para o desenvolvimento da criminalidade e para o direito penal duas linhas centrais de desenvolvimento que se fortalecem mutuamente:

- O processo de "globalização" proporciona novas oportunidades de execução de crimes que ultrapassam fronteiras, levando o direito penal a seus "limites territoriais" e exigindo novos modelos de um direito penal transnacional eficaz (cf. 2.1). ${ }^{6}$

- O desenvolvimento da "sociedade de informação e da sociedade de risco" gera novos riscos e uma criminalidade complexa, que também leva o direito penal principalmente no contexto de uma crescente política criminal global - a seus "limites funcionais" na proteção da sociedade e da liberdade do indivíduo e o coloca ante novos desafios categoriais (cf. 2.2). ${ }^{7}$

Essas duas linhas de desenvolvimento serão expostas detalhadamente a seguir, sendo analisadas, para cada uma delas, as modificações do desenvolvimento da criminalidade, a correspondente transformação do direito penal e as novas questões e abordagens de pesquisa resultantes.

\section{I GLOBALIZAÇÃO, CRIMES TRANSNACIONAIS E LIMITES TERRITORIAIS DO DIREITO PENAL}

O processo de globalização é - em especial a partir da década de 1990 - geralmente caracterizado pelo avanço da comunicação, interação e organização mundiais. ${ }^{8}$ Esse desenvolvimento não acarreta somente, como globalização econômica, problemas às economias nacionais, mas também leva ao desenvolvimento de uma nova criminalidade global, a modificações do direito penal e a uma crescente política criminal global. No centro dessas modificações e da análise a seguir está a progressiva "criminalidade transnacional”, que tem causas específicas (N. 1), conduz o direito penal clássico nacional aos seus limites territoriais (N. 2) e gera novas questões fundamentais (N. 3).

\section{I. I CRiminalidade transNacional}

As novas possibilidades de execução transnacional de delitos decorrem das crescentes "oportunidades de ultrapassagem de fronteiras" por pessoas e no intercâmbio internacional de mercadorias, serviços e dados na sociedade global. Essas possibilidades têm causas técnicas, econômicas e políticas e efeitos correspondentes.

a) Causas técnicas: "modificações técnicas" na globalização possibilitam o uso de redes de dados mundiais para a prática de delitos. Essas redes e a natureza imaterial dos dados conduzem a uma comunicação e organização mundiais, as quais também podem ser 
utilizadas para execução de delitos. Elas permitem que, com um computador, se modifiquem, em frações de segundo, dados de um sistema de computadores em um outro país, gerando sérias conseqüências. Além disso, os dados disponíveis na internet estão presentes em todo o mundo e podem ser acessados em vários Estados simultaneamente com um simples "clique no mouse". Um controle estatal dos fluxos de dados nas fronteiras territoriais de um país é, assim, praticamente impossível. ${ }^{9}$ Outras modificações técnicas - principalmente nas redes de transportes - facilitam, ainda mais, o massivo tráfego transfronteiriço de pessoas, mercadorias e serviços, que, em virtude dessas modificações, dificulta o controle e incentiva a prática de crimes transnacionais.

b) Causas econômicas: as "modificações econômicas" decorrentes da globalização geram possibilidades adicionais de prática de delitos transnacionais nos recémcriados mercados mundiais. Assim, por exemplo, a lavagem de dinheiro ocorre em um mercado financeiro mundial, caracterizado por suas rápidas transformações e que, em sua maior parte, se subtrai ao controle individual dos Estados. ${ }^{10} \mathrm{O}$ enorme comércio global de containers, da mesma forma, é cada vez mais difícil de fiscalizar. ${ }^{11}$ Em virtude da divisão internacional do trabalho, grupos econômicos com atuação internacional e ramificações no interior de numerosos territórios nacionais ampliam as possibilidades de atuação em nível mundial, tornando sua regulação cada vez mais difícil de ser feita individualmente pelos Estados. ${ }^{12}$ As conseqüentes possibilidades crescentes de integração e divisão de trabalho mundial no âmbito da economia legal são utilizadas também para a prática de crimes transnacionais, o que se mostra particularmente no desenvolvimento de mercados ilegais, especialmente no comércio internacional de pessoas, no comércio ilegal de drogas e armas, na pirataria internacional de produtos e no comércio internacional de órgãos humanos. ${ }^{13}$

c) Causas políticas: as "modificações políticas" da globalização geram, além disso, um enfraquecimento das fronteiras dos Estados em sua função de barreira às transações transfronteiriças. ${ }^{14}$ Assim, a decisão sobre o livre trânsito de pessoas, mercadorias e serviços na Europa, combinada com as modificações econômicas da globalização, gera novas oportunidades de prática de delitos na recém-criada zona econômica européia ${ }^{15}$ e para a facilitação de transações em mercados proibidos, cujo controle é mais difícil no âmbito das fronteiras intracomunitárias do que antes da abertura das fronteiras. ${ }^{16} \mathrm{~A}$ maior permeabilidade das fronteiras estatais também gera conseqüências de organização política e de política criminal, uma vez que, diante de diferentes relações de regulamentação entre os Estados no interior das fronteiras intracomunitárias, o mesmo fato pode, freqüentemente, ser deslocado de forma legal para o ordenamento jurídico mais favorável. Essa questão se mostra principalmente nos casos em que valorações divergentes ou interesses político-econômicos conflitantes 
levam a diferentes regulações nacionais do mesmo fato, a exemplo de pesquisa de células-tronco ou do aumento de impostos. Além disso, diferentes relações de regulamentação nas fronteiras externas favorecem a criminalidade em subvenções, de natureza aduaneira e tributária. ${ }^{17}$

\section{I. 2 Limites TERRITORIAIS DO DIREITO PENAL}

a) Limites da soberania territorial: os efeitos técnicos, econômicos e políticos da globalização postos acima sobre o desenvolvimento da criminalidade levam o direito penal clássico - baseado na soberania territorial -, cada vez mais freqüentemente, às suas "fronteiras nacionais". Esses limites territoriais do direito penal têm como pressuposto o fato de que o direito penal nacional dificilmente será aplicado em nível global, enquanto o reconhecimento da validade de suas decisões em territórios estrangeiros exigir demorados procedimentos de cooperação administrativa ou judiciária. ${ }^{18}$ Por isso, o direito penal apenas poderá superar esses novos desafios, na medida em que não se limitar a um campo de aplicação territorial e tornar-se, ele mesmo, global. ${ }^{19}$

b) Ampliações transnacionais: para o resultante desenvolvimento de um "direito penal com eficácia transnacional”, há duas abordagens distintas na esfera da atividade legislativa penal, entre os quais se encontram, ainda, numerosas formas mistas. ${ }^{20}$

- Por um lado, são desenvolvidos "modelos de cooperação estatal em assuntos penais", pelos quais são validadas as decisões de um sistema de direito penal nacional em um outro sistema de direito penal. Uma abordagem cooperativa como esta fundamenta tanto a clássica colaboração administrativa e judiciária como o novo princípio - há alguns anos preferido na União Européia - de reconhecimento recíproco de decisões judiciais. Esse novo princípio tem como base o princípio da confiança mútua e é o fundamento de numerosas Decisões-Quadro (existentes e planejadas) da UE, especialmente sobre o reconhecimento das penas pecuniárias e multas, o mandado de detenção europeu e o mandado europeu de obtenção de provas. ${ }^{21}$ Este princípio deve ser complementado na UE pelo princípio da "disponibilidade" dos dados existentes em outros ordenamentos jurídicos (como dados de registros penais), o que acarretará outras mudanças consideráveis na cooperação administrativa e judiciária clássica. ${ }^{22}$

- Por outro lado, desenvolve-se um "direito penal supranacional", com o qual o ordenamento jurídico-penal abrange um campo de aplicação territorial maior desde o início. Esse modelo é encontrado esporadicamente no direito sancionador da Comunidade Européia (por exemplo, na formação de cartéis e na proteção dos interesses financeiros da Comunidade Européia) e também - com uma abrangência mundial - no direito penal internacional. ${ }^{23}$ 
- Entre esses dois modelos existem numerosas "formas mistas" de uniões federativas e supranacionais, caracterizadas pela coexistência de ordenamentos jurídicos, centralizados e descentralizados (como no direito norte-americano) ou pela diferenciada divisão das atividades legislativa, judicial e executiva entre instituições centralizadas e descentralizadas. ${ }^{24}$ Exemplos de modificações dos modelos-base supracitados são o modelo suíço de competências federais e dos cantões ou o direito penal internacional, dependente do trabalho conjunto com os Estados nacionais. ${ }^{25}$

A análise aprofundada dessas diversas formas de cooperação estatal em matéria penal, assim como do direito penal supranacional, como diferentes modelos para a superação dos limites territoriais do direito penal, representa uma das futuras tarefas centrais da ciência do direito penal em relação aos desafios da globalização.

\section{2. i.3 Pesquisas pertinentes:}

EM DIREÇÃO A UMA TEORIA DA INTEGRAÇÃO INTERNACIONAL DO DIREITO PENAL Um primeiro tópico central do novo programa de pesquisa é formado pelo desenvolvimento dos fundamentos teóricos e práticos de um "direito penal transnacional eficaz". Para tanto, devem ser respondidas principalmente três questões centrais: (a) com que modelos e em quais sistemas desenvolve-se atualmente um direito penal transnacional eficaz e quais outras concepções de integração do direito penal podem ser imaginadas até aqui? (b) Como esses modelos e sistemas podem ser avaliados em relação às duas funções clássicas do direito penal - proteção da sociedade e liberdade do indivíduo? (c) Quais são as condições de aplicação para a execução dos diversos modelos e sistemas com vistas a espaços políticos e econômicos concretos?

a) Modelos e sistemas de integração do direito penal: os acima descritos "modelos fundamentais de um direito penal transnacional eficaz" podem ser encontrados, principalmente, no direito penal europeu, no direito penal internacional, nas Nações Unidas, em outras uniões políticas e econômicas, assim como em Estados federativos. ${ }^{26}$ A globalização e internacionalização da política criminal dela decorrente levaram, principalmente na última década, à sobreposição de diversos ordenamentos jurídico-penais nacionais, supranacionais e internacionais, que, em parte, contêm modelos diferentes. Isso se evidencia no combate à lavagem de dinheiro e ao bloqueio de bens na Alemanha, determinados por meio de regulamentos e recomendações do legislador alemão, da União Européia, das Nações Unidas e da OCDE. A análise do estado atual do direito precisa, portanto, distinguir modelos individuais para a coordenação de diversos ordenamentos jurídicos nacionais e o sistema jurídico geral. Este, por sua vez, é determinado por vários atores internacionais (não raramente heterogêneos) e composto de diversos ordenamentos jurídicos e outros subsistemas jurídicos, que se influenciam reciprocamente - por instrumentos 
"rígidos" ou "flexíveis". As atividades de diferentes atores nacionais, supranacionais ou internacionais na coordenação internacional do direito penal têm como efeito "sistemas com diversos níveis" e uma "fragmentação" do direito, que se torna ainda mais complexa por meio de sistemas de controle social e intervenções de atores privados, assim como de public private partnerships. ${ }^{27}$

b) Avaliação dos sistemas: a avaliação dos diversos modelos e dos sistemas jurídicos gerais por eles criados leva a numerosos problemas fundamentais. No âmbito dos "modelos de soluções de cooperação", apresenta-se, principalmente, a questão sobre até que ponto um Estado que procura cooperação jurídica na persecução de um determinado tipo de comportamento deve ser ajudado, se tal tipo de comportamento não é punível no Estado solicitado. Aqui ocorre uma colisão entre a aplicação transnacional efetiva do direito penal e a proteção do cidadão contra uma excessiva aplicação extraterritorial de direito estrangeiro. ${ }^{28}$

No campo dos "modelos de soluções supranacionais", por sua vez, trata-se principalmente das seguintes questões de direito do Estado: (i) a possibilidade de transferência de elementos do monopólio nacional da força para um contexto supranacional; (ii) relacionado a isso, a legitimação democrática de um direito penal supra-estatal; (iii) a transparência de seu surgimento; e (iv) um controle dos órgãos executivos responsáveis. Referidas questões, entretanto, apresentam-se não somente para um direito penal supranacional, mas também em relação a recomendações internacionais vinculantes - de direito ou de fato - para o direito penal nacional e para a cooperação entre países. ${ }^{29}$ No futuro, elas serão importantes não apenas para o direito penal da União Européia e para as recomendações do Grupo de Ação Financeira (Gafi) sobre lavagem de dinheiro, mas, principalmente, para o direito penal e de segurança recomendado pelo Conselho de Segurança das Nações Unidas.

Problemas de avaliação específicos resultam da acima constatada "fragmentação do direito” em diversos ordenamentos jurídicos e complexos normativos, como no nível dos Estados nacionais, da União Européia, das Nações Unidas e da OCDE. Esses “sistemas com diversos níveis" podem levar a colisões de sistemas normativos diferentes, assim como a contradições de normas ou valorações. Tais colisões encontram-se já na cooperação jurídica clássica, quando o dever de direito internacional público de um Estado em relação a outro, no contexto internacional, e a autorização limitada pela constituição, em contexto interno, são contraditórios. Elas aparecem também nas regras supranacionais no direito penal europeu, que podem contradizer o direito nacional (especialmente, o direito constitucional). Entretanto, esses conflitos tornam-se particularmente evidentes em sistemas jurídicos com fins diversos, como nos casos em que o direito das Nações Unidas (voltado a assegurar a paz) visa impor o congelamento de bens de terroristas em potencial, contradizendo 
as garantias processuais nacionais e internacionais (voltadas à proteção dos direitos humanos). ${ }^{30}$ Uma solução desses problemas concretos conduz a reflexões fundamentais sobre teoria do Estado, princípio da democracia, conceito de direito penal e legitimidade do poder de disposição no direito penal. Apenas sobre essa base podese desenvolver uma metanorma que, também nos casos de colisões, determina quais condições democráticas, de Estado de Direito e de direitos humanos uma norma internacional (seja de aplicação ou de criação de direito penal) deva preencher para preceder sobre determinados direitos protetivos nacionais ou regionais.

c) Determinação das condições para aplicação: para a política jurídica, coloca-se, então, a questão sobre os pressupostos e as condições para aplicação dos diversos modelos de integração do direito penal. Nesse contexto, é central a pergunta sobre a abrangência da necessária "harmonização do direito penal", tanto no direito material quanto no processual: a criação de modelos supranacionais de soluções para áreas geográficas maiores leva a uma completa harmonização jurídica, que, por sua vez, tem como pressuposto um consenso valorativo entre os ordenamentos jurídicos nacionais até agora vigentes. Como esse consenso é difícil de alcançar, e modelos supranacionais de soluções também exigem uma renúncia de soberania nacional, tanto a prática quanto a doutrina privilegiam, freqüentemente, os modelos de cooperação acima descritos. Entretanto, modelos de cooperação para o trabalho conjunto de diferentes ordenamentos jurídico-penais também podem funcionar somente com uma certa harmonização dos ordenamentos jurídicos em questão, o que é válido não apenas para a cooperação jurídica clássica, com seu princípio da dupla incriminação, vale também - como mostra a discussão sobre o mandado de detenção europeu - para modelos que se fundamentam no reconhecimento recíproco de decisões, uma vez que estes somente funcionam baseados em confiança mútua. Um mínimo de harmonização do direito também é necessário para todos os outros modelos de entrelaçamento de diferentes ordenamentos jurídico-penais. ${ }^{31}$

Um requisito indispensável para uma tal harmonização do direito penal é o “direito penal comparado" como instrumento central para a política jurídica e para a prática. ${ }^{32}$ A comparação do direito penal deve analisar os casos em que normas penais nacionais mostram especificidades - especialmente culturais - que sejam inerentes às correspondentes sociedades. ${ }^{33} \mathrm{Na}$ medida em que tais especificidades culturais efetivamente existem, apenas pode ser considerada uma aproximação lenta e "flexível” dos diversos sistemas jurídicos, com auxílio de modelos de leis penais não-vinculantes. ${ }^{34}$ No entanto, o reconhecimento e a aceitação de tais especificidades nacionais, para os modelos de cooperação, implicam questionar se e quando haverá prejuízo à aplicação do direito transnacional em face de normas penais específicas, vigentes apenas em Estados isolados, ou se a 
aplicação deve ocorrer com base no reconhecimento mútuo de decisões, sem atenção às diferenças jurídicas. A conseqüente desistência da “dupla incriminação" na cooperação jurídica é de especial importância, uma vez que um direito penal transnacional eficaz deve servir não somente à aplicação do direito penal, mas também à proteção do cidadão contra a incidência de normas penais estrangeiras, com cuja vigência ele poderia ignorar no lugar do delito. Esse problema de cooperação entre ordenamentos jurídico-penais diferentes pode aparecer, por exemplo, quando delitos com autores em vários Estados é valorado diferentemente pelos diversos ordenamentos jurídico-penais aplicáveis, ou quando são publicados na internet conteúdos que não são objeto de punição no lugar físico onde se encontra o servidor em questão, mas podem ser consultados também em um outro Estado, onde são puníveis. A discussão decisiva mantida em relação ao reconhecimento mútuo - no mandado de detenção europeu e no mandado europeu de obtenção de $\operatorname{provas}^{35}$ - sobre exceções materiais para o reconhecimento mútuo (por exemplo, em razão da ordre public européia ou nacional) ${ }^{36}$ e sobre limitações territoriais (por exemplo, na execução de delitos no próprio território $)^{37}$ demonstra a existência de problemas e questões fundamentais complexas, ${ }^{38}$ que têm, aliás, estreita relação com os limites funcionais do direito penal, abaixo analisados.

Com vistas à correlação do grau de integração e de harmonização, assim como da "eficiência do respectivo modelo de direito penal", deve ser especialmente analisado se os modelos de cooperação supracitados, com seu baixo grau de integração e harmonização entre os diversos ordenamentos jurídico-penais, enfraquecem não apenas a efetividade do trabalho conjunto - e com isso a função de proteção da sociedade pelo direito penal -, mas também as possibilidades de controle, transparência e consistência de todo o sistema e, conseqüentemente, também da proteção dos direitos de liberdade dos cidadãos. Um enfraquecimento dessa natureza poderia estar baseado no fato de que, em sistemas jurídicos crescentemente fragmentados, com maiores diferenças entre os subsistemas e com mais alta complexidade, também tende a aumentar a incidência de violações de normas, lacunas de regulamentação e déficits de controle. ${ }^{39}$ No exame dessa hipótese, deverá ser analisada a medida em que as fragilidades - nítidas em trabalhos conjuntos intergovernamentais europeus e na cooperação jurídica internacional - de modelos descentralizados e pouco harmônicos podem ser compensadas por meio de regulamentações especiais.

d) Conseqüências: as citadas problematizações criam uma série de questões fundamentais complexas, cuja análise simultânea panorâmica e sintética deverá gerar uma contribuição para uma abrangente "teoria da integração internacional do direito penal" e de um direito penal transnacional eficaz. ${ }^{40} \mathrm{O}$ assim criado "primeiro ponto 
central do novo programa de pesquisa" não pode, entretanto, limitar-se a uma resposta teórica das questões fundamentais, precisando - no caminho do direito comparado - investigar também quais experiências foram até agora alcançadas com os diversos modelos e sistemas de um direito penal transnacional eficaz. Faz-se necessária, portanto, uma abordagem empírica e baseada no direito comparado, tanto para a comprovação das diversas hipóteses e proposições teóricas quanto para o desenvolvimento de resultados capazes de ser utilizados, no tocante às questões centrais futuras da integração de direito penal europeu e mundial.

\subsection{NOVOS RISCOS, CRIMINALIDADE COMPLEXA E LIMITES FUNCIONAIS DO DIREITO PENAL}

A transposição de fronteiras territoriais é apenas um aspecto - mesmo que central e específico - das modificações da criminalidade na sociedade atual. Um segundo aspecto fundamental para o desenvolvimento da criminalidade na sociedade global de risco são "os novos riscos e a complexidade" da delinqüência em modificação. Como conseqüência desse desenvolvimento, o direito penal defronta riscos cada vez maiores e fatos cada vez mais complexos, seja na definição do comportamento penal relevante, como também no esclarecimento de delitos. Em virtude dessas modificações e dos já apresentados problemas da globalização, para determinados âmbitos delitivos - mesmo com ataques cada vez mais intensivos ao direito de liberdade dos cidadãos - a atuação do direito penal, freqüentemente, limita-se à sua função simbólica. ${ }^{41}$ A necessidade de uma prevenção reforçada e de um novo direito de segurança, propagada pela opinião pública e pela política, parece, na prática, colocar o direito penal perante a alternativa de ou se adaptar às novas necessidades ou deixar as regulamentações pendentes para ramos concorrentes do direito (como o direito de polícia, o direito do serviço secreto ou o direito de guerra). Esse desenvolvimento leva o direito penal aos seus "limites funcionais" não somente na garantia de proteção à sociedade, mas também e, especialmente, na sua tarefa de garantia da liberdade do indivíduo. ${ }^{42}$

\subsection{Novos RISCOS DA CRIMINALIDADE COMPLEXA}

Os novos riscos e a complexidade dos delitos na sociedade global de risco têm como causa - assim como a já analisada criminalidade transnacional - as "mudanças técnicas, econômicas e políticas" da sociedade atual. Tais modificações precisam ser mais detalhadamente estudadas, em razão de seus efeitos sobre a criminalidade e o direito penal, caso os problemas resultantes venham a ser conhecidos e soluções devam ser desenvolvidas. Trata-se aqui, principalmente, de riscos fortalecidos por novas dependências e vulnerabilidades da sociedade, possibilidades modificadas de cometer crimes e dificuldades específicas de esclarecimento eles, o que é especialmente claro no âmbito da criminalidade na internet, dos crimes contra a ordem econômica, da criminalidade organizada e do terrorismo. ${ }^{43}$ 
a) Causas técnicas: esses novos riscos da sociedade moderna e das formas de criminalidade complexa geradas por ela baseiam-se, em primeiro lugar, no "desenvolvimento técnico"44, que se mostra, prototipicamente, na crescente dependência da sociedade moderna de informação dos sistemas de computadores, freqüentemente violados, em virtude das lacunas da segurança a eles imanentes e da coligação mundial dos agentes. A dependência da sociedade moderna de informação em relação a tais sistemas é resultado da importância central que, hoje, a tecnologia da informação adquiriu para o funcionamento de economia, sociedade e Estado: sistemas de computadores assumem, como infra-estrutura técnica, não apenas a condução do fluxo de dinheiro, o arquivamento dos mais importantes segredos de negócios e empresas e a condução da produção de fábricas. Eles também são empregados em infra-estruturas centrais, como a vigilância aérea, a distribuição de energia elétrica, o tratamento de informações pela polícia e militares e em grandes setores do sistema de saúde. ${ }^{45}$ Os novos riscos técnicos nesses campos implicam dificuldades no esclarecimento dos respectivos delitos e, em parte, também no cometimento mássico de delitos. ${ }^{46}$ Assim, na corrida com os agentes criminosos, a persecução penal não somente sofre a pressão da adaptação no sentido técnico, mas também alcança, do ponto de vista quantitativo, os limites da sua capacidade.

Paralelamente, também resultam do moderno desenvolvimento técnico novos perigos de energia nuclear, química, biotecnologia, assim como de instalações técnicas com potencial lesivo sobre o homem e o meio ambiente. ${ }^{47}$ Entre estes se encontram não apenas riscos de uma proliferação de armas de destruição em massa entre terroristas, ${ }^{48}$ mas também do possível abuso de "produtos de dual-use" e técnicas correspondentes. A transferência de agentes patogênicos animais para as pessoas, a réplica biotecnológica de genes de vírus e bactérias (também de exterminados), as possibilidades de alteração desses agentes patogênicos por intermédio da tecnologia, assim como a publicação das necessárias seqüências de genes em revistas renomadas podem, no futuro, aumentar os riscos do terrorismo por meio do abuso dos "produtos de dual-use". ${ }^{49}$ Esses novos riscos poderiam aumentar sensivelmente se potenciais terroristas estivessem infiltrados em laboratórios de pesquisa adequados ou se eles se ocupassem intensivamente com o abuso da biotécnica, como o fazem atualmente com a técnica de armas e explosivos. ${ }^{50}$ Esses riscos técnicos são, em muitos casos, impossíveis de ser limitados pelo local, tempo e número de atingidos. ${ }^{51}$ Ao menos desde os ataques da seita japonesa Aum e do envio de cartas com Antrax nos EUA, cenários correspondentes também sempre têm lugar cativo nas estratégias de diferentes serviços de inteligência. $O$ desenvolvimento técnico leva, com isso, não apenas a novos riscos, mas também a novas necessidades de segurança da sociedade e modifica também sua percepção dos riscos e da criminalidade. ${ }^{52}$ 
b) Causas econômicas: riscos adicionais resultam de "modificações econômicas". No nível geral da economia, são importantes, primeiramente, os efeitos negativos da globalização para determinados grupos de pessoas, assim como uma melhor visibilidade dos diferentes níveis de prosperidade e das diferenças sociais. Esses desenvolvimentos causam violência crescente e movimentos migratórios no lado dos perdedores. ${ }^{53} \mathrm{O}$ controle da imigração ilegal e os efeitos gerados tornam-se, assim, um problema central das sociedades desenvolvidas. ${ }^{54}$

De outro lado, surgem grupos econômicos e fundos nacionais e multinacionais, que têm à disposição consideráveis meios financeiros e poder - também político. ${ }^{55}$ Abusos desse poder manifestam-se em corrupção, falsidades contábeis, crimes contra o meio ambiente e numerosas outras formas de crimes econômicos. ${ }^{56}$ Os riscos daí resultantes se mostram, por exemplo, nos mercados financeiros globais, cujo abuso pode ter grandes efeitos na economia como um todo. ${ }^{57}$ No entanto, o incremento e o tamanho de grupos econômicos multinacionais não têm apenas abusos financeiros como efeito, mas também uma transferência de poder do setor público para o privado, fortalecendo-se mediante a privatização de diversas funções públicas. Isso se evidencia na privatização de setores de segurança, na criação e atuação de empresas militares e de segurança, principalmente em relação aos conflitos armados e aos failed states. ${ }^{58}$ Para o direito penal, a forma de organização dos grupos econômicos - principalmente multinacionais - leva a problemas específicos de esclarecimento e de aplicação, que ainda podem ser aumentados por estratégias empresariais criminosas. ${ }^{59}$ Os problemas de controle do Estado que a isso correspondem são motivos importantes para a punibilidade da empresa, para o aumento de deveres de participação de particulares na investigação criminal, assim como para a crescente demanda por conceitos de auto-regulação. ${ }^{60}$

Aumentos de riscos resultam também das condições organizacionais econômicas modificadas, encontradas nas estruturas organizacionais de grupos criminosos: a melhoria do desempenho, o crescimento do poder e a periculosidade incrementada dos grupos criminosos organizados em virtude da divisão do trabalho, especialização e dinâmica do trabalho em grupo, não são fenômenos novos em crimes de bando e na criminalidade organizada. ${ }^{61}$ As diversas formas de ação conjunta de criminosos em grupos estruturados hierarquicamente, redes livres ou células frouxamente organizadas, podem se utilizar, de forma muito mais eficaz, das técnicas de comunicação mundiais, da globalização de mercados e da abertura de fronteiras. ${ }^{62}$ Mesmo a mobilização de um grande número de pessoas torna-se consideravelmente mais fácil com os meios de comunicação modernos principalmente em redes informalmente ligadas entre si e, por isso, são estruturas de solidariedade de difícil apreensão, ${ }^{63}$ como mostra o emprego da internet para propaganda terrorista ou divulgação de conteúdos racistas ou enaltecedores de violência. ${ }^{64}$ A conseqüente melhoria do desempenho na formação de grupos e na 
especialização tem efeitos nos campos dos crimes econômicos, da criminalidade organizada e em outras formas de criminalidade complexa.

c) Causas políticas: novos riscos conseqüentes a "modificações políticas" manifestam-se claramente no terrorismo motivado política, etnica ou religiosamente. Especialmente autores motivados pela religião entregam sua própria vida à atividade, pela qual, freqüentemente, não são mais influenciáveis pelo direito penal. Eles são organizados flexivelmente, em hierarquias rasas, redes de contato frouxas e células independentes, de difícil infiltração. Utilizam com sucesso a infra-estrutura técnica e as fontes dos seus oponentes para comunicação técnica, recrutamento, formação, fund raising e a sua utilização como arma. Atos terroristas são dificilmente reconhecidos com antecedência; sua grande periculosidade se manifesta na maioria das vezes apenas pouco antes da realização e, por isso, são raramente evitados. As ações não resultam apenas em grandes danos físicos, mas objetivam, por meio das mensagens e imagens divulgadas, efeitos psíquicos e fins políticos muito mais extensos: a violência terrorista espalha ansiedade e medo, que - fortalecidos pela mídia - visam atacar sensivelmente o conjunto econômico e político das sociedades modernas para torná-las suscetíveis a chantagens políticas. Com isso, o terrorismo busca, em um confronto assimétrico, quase bélico, primariamente objetivos políticos (como a retirada de Estados ocidentais de determinados territórios ou a desestabilização de governos moderados). Além disso, ataques terroristas pretendem provocar reações estatais e sociais que destruam os valores de liberdade das democracias ocidentais e conduzam novos simpatizantes e combatentes ao terrorismo. ${ }^{65}$

O terrorismo moderno fortalece, assim, um desenvolvimento que já se tornou claro em determinados países por meio da criminalidade organizada: na sociedade de risco moderna, a criminalidade pode levar a riscos políticos e, desse modo, a uma ameaça contra o Estado. Para a criminalidade organizada, isso se mostra não apenas nos países em que autores organizados ou empresas corrompem os agentes estatais. Também surgem riscos políticos, quando - por exemplo, na América Latina - traficantes de drogas concorrentes ou outros grupos de criminosos, relacionados a war lords locais e paramilitares, colocam em xeque o monopólio estatal da força, quando freqüentemente há uma ligação entre terrorismo e criminalidade organizada. ${ }^{66}$ Um desenvolvimento similar existe em países - principalmente, africanos - na exploração violenta de recursos naturais do solo por meio de empresas criminosas e líderes de conflitos armados locais. 67 Os riscos políticos criados dessa forma adquirem importância quando um país torna-se, por causa deles, um risco de segurança global, o que pode se dar em decorrência de falhas na sua função local de proteção, seja de fato (como failed state) ou normativamente (como "Estado de não-direito") e, assim, transforme-se, mundialmente, em crime 
havens (ou safe harbours) para grupos organizados de criminosos (por exemplo, na antiga Iugoslávia) ou para terroristas (como no Iêmen ou na Somália). ${ }^{68}$

Esses novos riscos políticos do terrorismo e da criminalidade organizada manifestam-se, em parte, também em confrontos violentos maiores e em "novas guerras". Não se trata mais, aqui, das conhecidas guerras entre Estados territoriais, mas, sim, de confrontos assimétricos entre Estados territoriais e redes organizadas - freqüentemente, internacionais. ${ }^{69}$ Os novos confrontos bélicos com estruturas de redes internacionais relativizam, por isso, as distinções clássicas de segurança interna e externa para os Estados territoriais, assim como de crime e guerra. As "novas guerras”, portanto, não raramente, são conduzidas - como na Bósnia, Afeganistão e Paquistão - pela polícia, militares, serviços secretos, comandos especiais e forças internacionais de intervenção. Depois dos ataques de 11.09.2001, a Otan e as Nações Unidas constataram, nessa medida, também a situação de defesa. Em vista do grande espectro dos diferentes ataques terroristas, no entanto, colocam-se difíceis questões sobre os limites entre o direito penal e o direito de guerra, sobre a diferenciação entre Estado de emergência “interno" e defesa “externa” e, também, sobre a abrangência do direito de legítima defesa do art. 51 do estatuto da ONU. ${ }^{70}$

A confusão entre segurança interna e externa, assim como entre crime e guerra, juntamente da crescente necessidade de defesa contra o perigo e de prevenção, coloca, assim, os sistemas jurídicos atuais diante de novos desafios categoriais, em que os "clássicos campos jurídicos" do direito penal, do direito de polícia e - em alguns países - também do direito de guerra criam um novo "direito de segurança”. ${ }^{71}$ O desenvolvimento de riscos políticos - intimamente relacionados à questão da globalização - fortalece também a necessidade da inclusão de questões de direito internacional público para a legitimação de intervenções da comunidade internacional com fins de efetivação da segurança internacional, segundo o Estatuto da ONU. ${ }^{72}$

Acrescem-se, ainda, outras modificações de caráter político, relacionadas à globalização, mas ultrapassam os problemas já analisados, de imposição de uma persecução penal transnacional. A crescente atuação de desenvolvimentos globais em fatos típicos locais e a cada vez maior mobilidade causam "contradições nas medidas valorativas sociais e nas normas estatais”. Isso se apresenta não apenas em determinados campos, de crimes na internet (por exemplo, no direito penal de proteção de dados ou em conteúdos enaltecedores da violência), em que as legislações especiais nacionais permanecem amplamente sem efeito no cyberspace global. ${ }^{73} \mathrm{O}$ mesmo fenômeno apresenta-se também, por exemplo, na pesquisa médica internacional, em que limites claros entre comportamentos permitidos e proibidos não podem mais ser determinados ou impostos em razão dos diversos regulamentos internacionais. ${ }^{74}$ Essa evolução alberga um grande potencial de conflitos, o que se torna visível no campo global da internet e na televisão mundial por satélite (em 
virtude da convergência de meios de comunicação), quando são divulgados pornografia, conteúdos de risco para adolescentes, declarações ofensivas à honra, propagandas de bebidas alcoólicas ou caricaturas contra religião. Surgem tensões quando, sob o teto da União Européia, diversos ordenamentos jurídicos devem cooperar estreitamente entre si, sendo, por exemplo, o suborno quase totalmente afastado em alguns ordenamentos e, em outros, aceito como parte do sistema social. Conflitos parecidos de diferentes expectativas normativas surgem também como conseqüência das migrações mundiais, da resultante sociedade heterogênea, e os conflitos decorrentes dos respectivos modos de vida e valores diversos, reunidos em um pequeno local. Exemplos para esse clash of cultures são assassinatos pela honra, vinganças de sangue ou novas dimensões da violência na Europa. ${ }^{75}$ As diferentes valorações de tipos de comportamento e os conflitos daí resultantes - por meio da internet, migração e outros fatores - transferem, assim, os antigos problemas internacionais sobre o dissenso de valores globais para o nível local, o que alberga riscos adicionais de escalação da violência.

d) Conseqüências: os novos riscos são freqüentemente acompanhados de maior complexidade dos tipos de delito, que se baseiam não apenas em causas técnicas ou econômicas, mas também em estruturas de autoria especiais, maior número de vítimas ou grande abrangência geográfica da execução do crime. Com esses novos riscos globais e com as complexas formas de criminalidade e seus problemas para a persecução, também ocorre, segundo vários autores, um enfraquecimento do Estado nacional. ${ }^{76}$ Entretanto, tal análise permanece em aberto, de modo que a "cooperação internacional de Estados" na sociedade global de risco possa confrontar efetivamente esse desenvolvimento com medidas técnicas de vigilância, com o recém-criado "direito de segurança" e seus componentes de direito de polícia, penal e militar, com novas redes internacionais, assim como com os daí criados aparatos de poder, e como isso levará a uma transferência individual de poder do setor público para o privado. ${ }^{77}$

No contexto desse desenvolvimento, são relegados ao Estado e à cooperação estatal sempre novas tarefas e poderes na obtenção de segurança, ${ }^{78}$ o que tem efeitos sobre o direito penal e os clássicos bens tutelados pelo direito penal, de modo especialmente grave, uma vez que na objetivada realização de segurança passam para o primeiro plano a garantia de prevenção e um novo direito de segurança, analisados a seguir.

\subsubsection{Limites FUnCionais Do Direito PENAL}

A análise anterior dos riscos modificados torna claros os motivos pelos quais o direito penal, na sua reação com os citados desafios, não raro encontra seus limites funcionais e procura novas respostas. Entretanto, a reação estatal e da sociedade aos 
novos desafios é mais complexa do que os motivos e alternativas de "direito penal do inimigo" e "direito penal de cidadão", discutidos atualmente não apenas no tocante as suas causas, mas também em relação às possíveis soluções. ${ }^{79}$ Para os novos desafios da "sociedade global de risco", encontram-se, assim, na política criminal duas respostas diferentes, com diversas facetas:

- A proposta de solução prevalecente - principalmente em Estados onde o terrorismo torna-se visível - objetiva uma ampliação e "desfronteirização" do direito penal, assim como sua burla por meio de outras disciplinas de um novo direito de segurança (infra a).

- A segunda proposta de solução compõe-se do desenvolvimento de medidas alternativas (fora do direito penal e, especialmente, também fora do direito) de prevenção criminal (infra b).

a) Desfronteirização do direito penal e novo direito de segurança: a "proposta de solução de um alargamento do direito penal” para além de seus limites atuais é genericamente caracterizada por meio de uma aparelhagem mais forte do direito penal em relação à prevenção e à segurança, além da conseqüente atuação já na fase anterior à execução do crime e da suspeita do fato. ${ }^{80}$ Nesse contexto, trata-se - nas categorias do sistema alemão de classificação - de diversos ordenamentos jurídicos de (aa) antecipação da punibilidade no direito material; (bb) ampliação de conceitos preventivos de observação, a redução de garantias e a criação de competências especiais no direito processual penal; (cc) fortalecimento dos deveres de colaboração de particulares na fase anterior e fora do processo penal; (dd) a criação de task forces interinstitucionais e internacionais em uma nova "arquitetura de segurança"; além da (ee) dissolução de categorias jurídicas clássicas e da criação de um novo direito de segurança. A combinação desses desenvolvimentos fica evidente na codificação americana da war on terror (infra ff.).

aa) No "direito material, as antecipações da criminalidade" se mostram, por exemplo, na reação aos riscos de estruturas de autoria de crimes complexos e, especialmente, na apreensão de execução de crimes com divisão de tarefas, por grupos organizados de criminosos, redes e células: legislador e jurisprudência reagem mundialmente - no tocante à criminalidade organizada e ao terrorismo -com a criação de delitos de organização (especialmente, o apoio a criminosos e organizações terroristas), tipos penais de conspiração (conspiracy), figuras especiais de imputação (como joint criminal enterprise, vicarious liability e strict liability), assim como outras antecipações da punibilidade. ${ }^{81}$ Também no campo da criminalidade econômica (e também dos crimes contra o meio ambiente) e no da criminalidade organizada, torna-se claro um correspondente desenvolvimento de direito material para os novos bens jurídicos supra-individuais, delitos de perigo abstrato e delitos de posse. ${ }^{82}$ A ligação desses tipos penais de antecipação com os paradigmas de prevenção acima analisados fica 
evidente nas discussões no Ministério da Justiça sobre a criminalização antecipada do $\S 129$ a StGB: ${ }^{83}$ a atualmente discutida criminalização da participação em uma formação terrorista permitiria, a fim de evitar eventuais ataques terroristas contra pessoas e potenciais "suicidas", agir já antecipadamente (por exemplo, na sua volta para a Alemanha) com os meios do direito penal, especialmente de modo "preventivo". ${ }^{84}$ A antecipação da proteção de direito penal é freqüentemente completada por meio de um aumento das penas cominadas. ${ }^{85}$

bb) Os riscos aumentados, assim como as dificuldades de esclarecimento e comprovação da nova criminalidade complexa, têm efeitos notáveis no direito processual. Também aqui se encontram fortalecidas, primeiramente, "medidas de efeito preventivo na fase antecedente à suspeita do crime", 86 em especial medidas de vigilância e de intervenção técnico-informativas secretas, que investigam conversas, telefonemas, dados de computadores, locais de estada e contas de cidadãos, unindo vários dados sobre eles. ${ }^{87}$ De tais medidas interventivas podem-se desenvolver futuramente novos sistemas globais de vigilância de "suspeitos" ou pessoas "perigosas", 88 fundamentado em perfis de risco. O conceito de "prevenção para a persecução penal", ${ }^{89}$ relacionado a tais medidas, descreve nitidamente a conseqüente mistura entre prevenção e repressão. Assim, fortalece-se a tendência de uma utilização preventiva imediata do direito penal, que já era clara anteriormente, nos motivos para prisão preventiva, assim como na expansão das medidas de segurança e, especialmente, com a medida de segurança após cumprimento de pena. ${ }^{90}$

Além disso, ocorre uma "redução das garantias e formas de proteção" no direito processual penal. Em diversos ordenamentos jurídicos estrangeiros, isso significa novas possibilidades para prisão policial mais longa de pessoas suspeitas (que, na maioria dos casos, também serve a objetivos preventivos $)^{91}$ ou de facilitações de provas (que freqüentemente levam a uma ampliação do direito penal material). ${ }^{92} \mathrm{Na}$ Alemanha, a relevante discussão sobre os limites jurídicos do combate preventivo do terrorismo pela aplicação de tortura e pelo abatimento de aviões seqüestrados ${ }^{93}$ esclarece quanto os novos riscos colocam limites tradicionais do direito penal em xeque. Dificuldades relativas ao esclarecimento e violações mássicas de normas, aliás, levam ainda à renúncia a uma imposição coerente das normas em favor de estratégias consensuais, como em acordos processuais ou medidas de resolução alternativas. ${ }^{94}$ Os problemas de uma tal desformalização se evidenciam nos EUA quando, em casos isolados, um acordo para o encerramento de um processo é feito com a indicação das autoridades persecutórias referente a um possível envio do processo penal para a tutela/competência militar para enemy combatants. ${ }^{95}$

Além disso, ordenamentos jurídicos isolados criam "competências especiais (via de regra regionais) para a perseguição e julgamento de determinados âmbitos delitivos" (por exemplo, para a criminalidade econômica, a criminalidade organizada, o terrorismo ou a criminalidade complexa), ${ }^{96}$ assim como, em parte, medidas especiais 
de investigações também podem ser utilizadas para delitos comuns, ${ }^{97}$ em virtude de cláusulas amplas de aplicação ou dos catálogos de tipos penais. Nesse contexto, também são consideradas medidas especiais exclusivas para determinados grupos de agentes, cujo comportamento é generalizado como uma ruptura permanente com a sociedade, o que pode ser denominado de forma emblemática com a expressão "direito penal inimigo". 98 Caso essa expressão não somente descreva criticamente os atuais desenvolvimentos, mas também seja formulada como recomendação de atuação, isso torna os perigos de uma "desfronteirização" do direito penal especialmente claros.

cc) Modificações fundamentais adicionais no sistema de coordenadas do direito penal e extrapenal - como reação a dificuldades estatais de esclarecimento - se mostram nos "deveres de colaboração de particulares" para o controle, também na fase antecedente e externamente à persecução penal. Trata-se tanto da utilização de conhecimentos técnicos específicos (como em esclarecer o âmbito complexo da tecnologia de computadores ${ }^{99}$ ) quanto da criação, divulgação e avaliação de bases de dados privadas para fins de prevenção e precaução para a persecução penal, o que é explícito não só no combate à lavagem de dinheiro ${ }^{100}$ e no controle das negociações de títulos e valores mobiliários ${ }^{101}$, mas também na área da vigilância das telecomunicações, com obrigações de criação de possibilidades técnicas de vigilância e de conservação de dados. ${ }^{102}$ A correspondente privatização da persecução penal (ou de sua precaução) e da garantia de segurança ${ }^{103}$ é, em parte, também relacionada com a penetração em relacionamentos de confiança privados (por exemplo, na inclusão de advogados no combate à lavagem de dinheiro). ${ }^{104} \mathrm{O}$ desejo de utilização de bancos de dados privados para a garantia de segurança aumentará ainda mais no futuro, especialmente para o targeting de suspeitos de terrorismo. Atualmente, existem ferramentas de software com as quais é possível, em pouco tempo, compor detalhados perfis de personalidades a partir de fontes e bancos de dados públicos. As grandes quantidades de dados pessoais nas mãos de empreendimentos particulares, assim como a correspondente cobiça dos responsáveis privados e públicos pela segurança, no futuro levarão a uma nova dimensão da proteção de dados e à participação de particulares na garantia da segurança em muitos países.

dd) Para a otimização das investigações, as até agora separadas competências das autoridades de segurança, assim como os até agora distribuídos conhecimentos e as limitadas possibilidades de consultas a bancos de dados separados, são cada vez mais unificados por meio de grupos de trabalhos com representantes de diferentes áreas de investigação - de direito penal e extrapenal. Na Alemanha, as correspondentes task forces interdisciplinares no contexto de uma nova "arquitetura da segurança” e de um "princípio geral de combate" trabalham conjuntamente (representantes da procuradoria-geral da república, polícia, alfândega, autoridades para estrangeiros, serviço secreto e entidades militares), utilizando, ainda, conhecimentos de entes privados responsáveis pelo combate à lavagem de dinheiro. Nesse 
trabalho conjunto e nos "arquivos antiterror", que sustentam tal trabalho, desaparece ainda mais a diferença - central para o direito de segurança alemão - entre prevenção e repressão. ${ }^{105}$ Também internacionalmente as redes transnacionais de criminosos são enfrentadas cada vez mais com as task forces multifuncionais e as redes estatais internacionais. ${ }^{106}$

Essa "nova arquitetura de segurança”, com suas novas estruturas e instituições flexíveis, é, freqüentemente, caracterizada por pouca transparência e falta de controle. "Déficits de controle" ocorrem geralmente quando o trabalho conjunto e as competências de intervenção são predeterminados em níveis supranacionais e regulados por meio de cooperação intergovernamental dos Poderes Executivos, uma vez que aqui, comparativamente ao nível nacional, há maior déficit de democracia e transparência. A importância fática de manuais de polícia e de coletâneas de best practices é reforçada quando são tomados como base do acquis perante os países em processo de adesão à União Européia. A fragmentação dos grêmios internacionais que tratam de questões de segurança e a criação conseqüente de novas formas de coordenação - como o procedimento de peer-review da OCDE, do Conselho da Europa, da Comunidade Européia ou da ONU ${ }^{107}$ - fortalecem a falta de clareza e transparência do trabalho conjunto entre governos. Isso vale especialmente para a cooperação dos executivos em redes flexíveis e maleáveis. Os correspondentes problemas de controle e de legitimação nos chamados sistemas com diversos níveis 108 tornam-se claros na perseguição internacional ao terrorismo, quando amplas competências do Executivo são reclamadas e exercidas freqüentemente também em âmbito extraterritorial -, especialmente para a detenção de suspeitos, para o "congelamento" de seu patrimônio, para a escuta de telecomunicações e para o acesso aos dados da Society of Worldwide Interbank Financial Telecommunication (Swift). ${ }^{109}$ Aqui, abundam problemas dos limites territoriais e funcionais do direito penal.

ee) No curso desse desenvolvimento, "as categorias jurídicas clássicas diluem-se" juntamente das funções de proteção por elas garantidas: a necessidade de prevenção e investigação de pessoas "suspeitas" ou "perigosas" relativiza, em grande parte, "a diferenciação entre reação de direito penal e a defesa policial contra perigo", conceito central para o direito penal continental europeu, especialmente quando a obtenção de informações no âmbito da criminalidade organizada e do terrorismo não parte de uma suspeita de crime, mas, sim, de um risco de segurança - em parte abstrato. Aqui, a orientação preventiva tem como efeito que novas medidas de intervenção contra o terrorismo sejam reguladas não apenas no direito processual penal, mas, também, pelo direito policial e pelo direito do serviço secreto. ${ }^{110}$ Assim, a segurança também é buscada pelo direito administrativo geral, por exemplo, com o direito de comércio exterior, de telecomunicações e de imigração. Uma vez que estrangeiros sejam freqüentemente considerados perigosos e, ademais, seja 
possível instituir medidas especiais no direito de imigração e de permanência, notase em diversos ordenamentos jurídicos o desenvolvimento de um "sistema jurídico dual”, diferenciando "cidadãos nacionais e estrangeiros", possibilitando aos últimos, além da tradicional extradição, em parte, privação de liberdade sem acusação, renúncia à presunção de inocência, assim como um ethnic profiling. ${ }^{111}$ Assim, os direitos do "estranho" são circunscritos não apenas pelo direito de guerra, mas já no direito nacional interno.

A já apresentada dissolução das distinções entre segurança interna e externa e entre crime e guerra nas novas "guerras assimétricas" dos Estados territoriais contra as redes internacionais leva Estados isolados - na luta contra o terrorismo - ao emprego de "medidas de direito de guerra". O direito de guerra amplia sensivelmente as medidas de intervenção do Estado. ${ }^{112} \mathrm{~A}$ discussão sobre a aplicação de direito internacional de guerra contra terroristas ${ }^{113}$ - até agora travada principalmente nos EUA e em Israel - também alcançou, no início de 2007, o direito alemão: uma proposta de lei do Ministro de Assuntos Interiores alemão pretende possibilitar o abatimento de aeronaves seqüestradas por terroristas - tido como inconstitucional pela corte constitucional em sua decisão sobre a lei de segurança da aviação -, com base no direito internacional de guerra, por meio da nova redação do art. 87 "a" parágrafo 2 GG, que permite o emprego das forças armadas para um "caso comparável à situação de defesa”. ${ }^{114}$

Essa "dissolução das distinções políticas e jurídicas" entre segurança interna e externa, crime e guerra, prevenção e repressão, polícia e serviço secreto e polícia e exército ${ }^{115}$ produz, ao todo, um "novo direito de segurança" complexo e de várias camadas, que objetiva principalmente evitar perigos e que, no direito penal clássico, tem um certo papel limitado. A conseqüente transferência de tarefas para outros ramos do direito, fora do direito penal, gera o perigo (no direito de polícia, mas também no direito do serviço secreto, de estrangeiros e de guerra) de que esses novos ramos do direito não possam garantir um nível de proteção comparável ao do direito penal, o que não vale apenas para as exigências de direito material da precisão dos tipos penais e para a garantia do princípio da culpa no direito penal, que abrangem mais do que a mera garantia do princípio geral constitucional de proporcionalidade. ${ }^{116}$ Perigo semelhante existe também no tocante ao limiar de intervenção e ao ponto de referência da suspeita do crime (que, no direito de polícia, é substituído por um perigo), aos deveres de participação dos atingidos (por exemplo, no direito tributário), às questões de ônus da prova, ao juiz natural e demais medidas de proteção, ao deslocamento de competências do Judiciário para o Executivo ou à participação do Parlamento no desenvolvimento das respectivas regulamentações. ${ }^{117}$ Paralelamente, existe o risco já mencionado de, além do deslocamento para fora do direito penal, com o tempo, também se modificarem as bases de proteção intrínsecas ao direito penal. 
ff) Essa alteração das coordenadas no controle da criminalidade e na contenção de perigos se mostra com particular nitidez à vista do exemplo das medidas norteamericanas contra o terrorismo. O novo conceito desenvolvido pelo governo norte-americano de "war on terror" serve não apenas para fins retóricos de mobilização de todas as forças (como é utilizado em uma "guerra contra a pobreza"), e sim para a legitimação de intervenções jurídicas que não seriam possíveis em uma situação fora da guerra em respeito aos princípios clássicos do law enforcement. ${ }^{118}$ As pretensas competências do direito de guerra e outras competências impostas nesse contexto são interpretadas pelo Executivo de modo extremamente amplo e juridicamente discutível. Por isso, a war on terror americana comprova de forma impressionante que as destacadas modificações isoladas do sistema, no caso de uma combinação, podem levar a graves limitações dos direitos de liberdade clássicos, mesmo em Estados com longa tradição na proteção dos valores da liberdade. Por tal motivo, as peças fundamentais desse desenvolvimento e sua possível interação devem ser apresentadas, brevemente, em um "contexto geral", com base no exemplo norte-americano.

Com o conceito norte-americano de war on terror, são instituídas, primeiramente, competências de direito de guerra que ultrapassam largamente as medidas permitidas em direito penal ou direito de polícia: o direito de guerra permite diferentemente do direito processual penal ou do direito de polícia - a morte de combatentes ativos em casos específicos e, assim, eventualmente, também a de terroristas. ${ }^{119}$ Além disso, combatentes suspeitos de terrorismo podem - sem qualquer prova de um fato penal concreto - ser mantidos presos por todo o tempo de duração dos conflitos. O ponto de partida teórico para a justificativa de uma guerra é a tese do governo dos EUA de que o Taleban e a Al Qaeda declararam guerra aos EUA e estão em situação bélica permanente com estes. No entanto, tal abordagem é ampliada para além do conflito territorialmente limitado com o Taleban no Afeganistão para toda forma de terrorismo internacional, ${ }^{120}$ de modo que, na opinião do governo norte-americano, terroristas potenciais podem ser atacados no mundo todo e ser mantidos presos ao longo de toda a duração da war on terror. ${ }^{121}$

O novo instrumental de intervenção é assim completado com um segundo conjunto de atribuições especiais, que também se baseiam no conceito de guerra. $\mathrm{Na}$ opinião do governo, por causa da guerra duradoura contra o terrorismo internacional, o presidente pode se apoiar nos seus war powers constitucionais e estabelecer, como commander in chief, amplos regulamentos executivos que, em tempos de paz, seriam exclusividade do Legislativo. ${ }^{122}$ Com essas presidential orders, pretensos terroristas foram declarados enemy combatants, permitiu-se o interrogatório de cidadãos nos EUA por meio da National Security Agency sem autorização judicial e criaram-se tribunais militares especiais para os processos penais contra supostos terroristas. ${ }^{123}$ 
O novo instrumentário de intervenção, caracterizado pelo direito de guerra, também deve justificar, como direito especial externo ao law enforcement clássico, a desconstrução de garantias processuais e a criação de procedimentos segundo a necessidade, o que vale principalmente para modificações nas normas relativas a provas perante as Federal Rules of Evidence, as Federal Rules of Criminal Procedure e o Uniform Code of Military Justice (UCMJ). ${ }^{124}$ Paralelamente à introdução de procedimentos sigilosos (in camera-Verfahren) e à utilização de hearsay evidence, o uso dos depoimentos obtidos deve depender, em parte, apenas de questões de confiabilidade (reliability) das informações, mesmo no caso de emprego de métodos de tortura. ${ }^{125}$ Originalmente, esse princípio deveria até possibilitar que os suspeitos de terrorismo identificados como enemy combatants fossem privados de qualquer possibilidade de acesso a um tribunal ordinário. Assim, a revisão das acusações individuais contra os detentos ocorria exclusivamente perante tribunais militares, os chamados Combatant Status Review Tribunals (CSRT). Nesse ínterim, a Suprema Corte permitiu o acesso dos presos em Guantánamo aos tribunais civis norte-americanos. ${ }^{126}$ Entretanto, foi dado novo impulso à revogação desse processo com o Detainee Treatment Act e o Military Commissions Act de 2006, garantindo-se a competência dos tribunais militares. ${ }^{127}$

A atribuição categórica da luta contra o terror aos militares possibilita, enfim, também a detenção de pessoas suspeitas em outras prisões que não as civis. A detenção em instituições militares permite ao governo norte-americano manter presos estrangeiros longe do território estadunidense e, assim, segundo seu entendimento, evitar a incidência do campo de proteção material dos direitos dos cidadãos contidos na constituição americana. ${ }^{128}$ Mediante uma forma de interpretação específica de obrigações de direito internacional, foi negada pelos EUA até mesmo a aplicação de normas humanitárias internacionais. ${ }^{129}$ No entanto, desde a decisão da Suprema Corte americana no caso Hamdan, deve ser observado, no mínimo, o art. 3, comum às quatro Convenções de Genebra. ${ }^{130}$ Nesse momento, entretanto, mostra-se também que uma grande parte desse modo de agir é condicionada ou possibilitada por meio de especificidades da doutrina constitucional dos EUA. ${ }^{131}$

Incluindo-se o mais novo relatório do relator especial do Conselho da Europa, Dick Marty, assim como um conjunto de relatórios da mídia, então, deveria existir ainda um outro nível, em que medidas tomadas na guerra contra o terror seriam classificadas como contrárias a compromissos nacionais e deveres internacionais. Entre tais medidas, destacam-se as extraordinary renditions da CIA, que envolvem a captura de suspeitos de terrorismo e sua conseqüente detenção e interrogatório fora dos EUA e sem o devido processo legal. ${ }^{132}$ Além disso, incluem-se aqui os métodos agressivos e desumanos de interrogatório por parte dos membros da CIA e das Forças Armadas. ${ }^{133}$

As medidas tomadas nos EUA depois dos ataques de 11.09.2001 vão muito além das medidas continentais européias e tornam-se nítidas as atuais mudanças dos 
limites funcionais do direito penal. A análise de até que ponto as novas medidas de intervenção e o novo direito de segurança ignoram os limites clássicos da proteção dos direitos civis; e até onde são de fato eficazes e quais os seus efeitos indesejados também são freqüentemente negligenciados pela política européia e em outras regiões em vista das novas ameaças. O mesmo se aplica à busca por medidas alternativas de controle social que intervenham de modo menos intenso e às quais, futuramente, se deverá recorrer com ainda mais freqüência, em vista dos novos riscos. Elas serão analisadas a seguir.

b) Conceitos alternativos: as respostas aos novos riscos dos crimes complexos podem ser dadas não apenas com uma desfronteirização do direto penal, mas também com a citada "segunda estratégia de solução" de um desenvolvimento de medidas extrapenais alternativas para a prevenção criminal e o controle social informal e, especialmente, também extrajurídicas. Tais medidas abrangem um amplo espectro de possibilidades. ${ }^{134}$ Em um primeiro grupo de "medidas de proteção alternativas de efeito pró-ativo”, tem-se a proteção da própria vítima em potencial por meio da técnica (como no campo do Cybercrime), ${ }^{135}$ o controle procedimental preventivo (por exemplo, no direito médico), ${ }^{136}$ as regras processuais de direito administrativo (como em medidas de combate à corrupção), ${ }^{137}$ a eliminação de problemas sociais (por exemplo, causas de terrorismo) ${ }^{138}$ e de outras causas criminógenas (em especial, no campo dos crimes em subvenções ${ }^{139}$ e na chamada prevenção de estrutura (a exemplo do crime organizado). ${ }^{140}$

Um segundo grupo de medidas engloba "sistemas de controle alternativos". Aqui se encontram não apenas por contravenções e de direito administrativo e pretensões de indenização de direito civil (também sob a forma de indenizações múltiplas), mas também por estratégias de solução diferenciadas (mediação, acordo entre criminoso e vítima ou comissões de verdade no campo de crimes contra as pessoas), ${ }^{141}$ assim como a auto-regulação e co-regulação de Estado e particulares (destaque para o campo da internet e da imprensa). ${ }^{142}$ Nesse último campo, regulamentos norte-americanos e italianos para a observação de programas de Compliance no cálculo de penas para sanções a empresas apresentam modelos de solução especiais, que estimulam medidas de prevenção privadas ou medidas de auto-regulação com sanções de direito penal ou privilégios. ${ }^{143}$ Codes of ethics e codes of conducts dos cientistas devem evitar - paralelamente às já existentes regulamentações legais -, principalmente as já citadas possibilidades de abuso de produtos de dual-use de risco no campo das life sciences ${ }^{144}$ - ainda mais amplo -, combater a tentação de comportamentos não-éticos na pesquisa.

Com a aplicação desses princípios de controle alternativos ou complementares é possível ultrapassar, com freqüência, não apenas os limites funcionais, bem como os limites territoriais do direito penal clássico, uma vez que medidas de prevenção 
“privadas” de empresas e associações, por exemplo, não esbarram nos mesmos limites nacionais que o direito penal. Isso se torna evidente quando empresas de atuação internacional se obrigam, por meio da autovinculação, ao bloqueio de conteúdos ilegais na internet. ${ }^{145}$ Observando-se como característica da globalização a supracitada perda de poder do Estado e o início do "domínio supranacional dos funcionários da economia mundial”, ${ }^{146}$ uma transição reforçada para a inclusão de medidas (também) não-estatais no controle social é uma possibilidade de solução natural, que pode adquirir cada vez mais importância no futuro. No campo internacional, tais medidas de atores privados e formas mistas de private public partnerships tornam os mencionados sistemas com diversos níveis ainda mais complexos e complicados. A fragmentação do direito desenvolve-se, assim, para uma fragmentação mais ampla dos sistemas de controle sociais. ${ }^{147}$

Os conceitos de controle alternativos e, principalmente, particulares oferecem não apenas novas chances, mas também, em parte, abrigam "riscos jurídicos e políticos". Tais riscos estão principalmente na desestatização do controle da criminalidade, assim como na correlacionada perda de garantias processuais penais, do controle jurídico do Estado e da legitimação democrática das intervenções em direitos fundamentais, o que se mostra, por exemplo, quando as supracitadas vinculações próprias dos provedores de internet levam à proibição de conteúdos ilegais por medo de sanções, acarretando uma censura privada ampla e descontrolada. ${ }^{148}$ Isso também é nítido quando federações esportivas internacionais impõem graves sanções por doping que, segundo critérios jurídico-penais, são instrumentos de strict liability e violam a presunção de inocência. ${ }^{149}$ As questões relativas aos limites da privatização do direito penal foram, entretanto, pouco esclarecidas até agora. Nesse esclarecimento, deve ser analisada criticamente a crescente não-diferenciação entre sociedade e Estado, principalmente no âmbito da filosofia do direito. ${ }^{150}$ A conseqüente equiparação entre sociedade e Estado enfraquece o potencial estatal de mediar e neutralizar conflitos sociais, levando a que a parte mais fraca (ou seja, o acusado) não seja mais protegida pelo Estado, como até agora o é.

\subsubsection{Pesquisas pertinentes:}

PARA UMA TEORIA DOS LIMITES FUNCIONAIS DO DIREITO PENAL

Em virtude do desenvolvimento aqui analisado, um segundo ponto central do novo programa de pesquisa do Instituto Max-Planck de direito penal estrangeiro e internacional de Friburgo constitui a investigação dos fundamentos práticos e teóricos para os limites funcionais do direito penal. Na busca pelas peças fundamentais para construir uma "teoria dos limites funcionais do direito penal", trata-se principalmente de três questionamentos centrais: (a) até que ponto ocorrem alterações nos limites funcionais do direito penal em ordenamentos jurídicos diferentes e até onde tais alterações são justificadas por novas ameaças ou quais outras causas as fundamentam? 
(b) Em que medida as modificações dos limites funcionais do direito penal melhoram de fato a segurança na sociedade, o quanto ameaçam a liberdade dos cidadãos e quais princípios e diferenciações podem ser desenvolvidos para uma política criminal futura? (c) Quais medidas alternativas ou complementares (extrapenais) estão disponíveis para a diminuição de riscos, quais efeitos têm tais medidas sobre a segurança da sociedade e sobre a liberdade dos cidadãos e quais princípios e diferenciações são, assim, relevantes para uma política criminal futura?

a) Modificações e suas causas: a busca pelas causas das modificações de direito penal acima analisadas não toma em consideração apenas a dimensão fática esquematizada dos novos riscos. Devem ser pesquisados também outros possíveis motivos para a atual desfronteirização do direito penal; por exemplo, uma crescente necessidade de segurança na sociedade de risco, ${ }^{151}$ uma modificação do medo do crime, ${ }^{152}$ a perda de valores na sociedade global, o relacionado clamor por “tolerância zero", uma reação irracional a riscos de rara ocorrência, mas com grande número de casos de morte, ${ }^{153}$ uma possível aplicação contraproducente do direito penal, por meio de governos nacionais e instituições supranacionais para (re)conquistar a confiança e eleitores, assim como uma dramatização dos perigos por meio da imprensa, associações de proteção à vítima ou entes isolados responsáveis pela segurança. ${ }^{154}$ Nesse contexto, também é relevante a questão sobre até que ponto novos riscos específicos levam apenas a autorizações especiais de intervenção em relação a estes riscos ou se são tomados como ponto de partida para um endurecimento penal geral.

b) Efetividade e garantias jurídicas: as questões sobre os efeitos das novas mudanças do direito penal atingem, além da praticabilidade e da intensidade de intervenção das novas regras, especialmente os limites que os objetivos clássicos do direito penal, assim como a dignidade humana, o princípio da culpa, o princípio do estado de direito, o princípio da separação de poderes e o princípio da democracia (este, entretanto, questionado supranacionalmente) podem ser contrapostos a uma desfronteirização do direito penal, ${ }^{155}$ o que vale, por exemplo, para utilização de novas medidas de investigação baseadas na tecnologia da informação, para a modificação de considerações de direito processual penal no tocante aos novos riscos, para alteração do direito penal para a prevenção, para a relação entre direito penal e direito de polícia e para a inclusão de particulares no controle da criminalidade.

Em virtude da transferência de matérias reguladas pelo direito penal para o direito (administrativo) da polícia, da alfândega, do serviço secreto e das repartições públicas para estrangeiros, assim como (em alguns países) dos militares, interessam principalmente também os fundamentos dogmáticos do novo e abrangente direito de segurança e a análise das garantias vigentes do Estado de Direito. ${ }^{156}$ 
No caso e na medida em que a análise empírica da atual situação de ameaça justifique um fortalecimento dos poderes preventivos estatais, coloca-se no caso concreto a pergunta, se medidas preventivas necessárias não deveriam, na verdade, ser reguladas em uma "nova via" do direito de segurança, no direito de polícia, no direito dos serviços de notícias, no direito administrativo em geral ou no direito penal. Tal problemática torna-se mais clara com o questionamento, sobre se e como agir contra uma pessoa que vai a um local de formação de terroristas, retorna de um local de formação de terroristas ou que por outros motivos é suspeita de ser um terrorista "suicida" ou de ser "perigosa”, sem que ela tenha, entretanto, cometido um crime. O direito americano acima descrito demonstra as possibilidades e os perigos do novo "direito de guerra", que pretende manter presos os inimigos por tempo indeterminado. ${ }^{157} \mathrm{O}$ direito francês, por sua vez, prolongou a possível duração da detenção policial geral do direito penal em vários momentos - com destaque para a criminalidade organizada e o terrorismo - para quatro ou seis dias e, paralelamente - com o objetivo de obter confissões -, enfraqueceu as garantias do Estado de Direito para suspeitas qualificadas de crime e para os prazos para a apresentação do preso ao juiz e a comunicação ao advogado. ${ }^{158}$ O direito inglês, com o seu recém-criado Control Orders, mostra, por seu lado, as opções e riscos de um sistema unificado de direito penal e policial, que estabelece amplos poderes de salvaguarda da polícia e dos tribunais, prevendo processos formalizados para a derrogação de direitos humanos, segundo o art. 15 da Convenção Européia dos Direitos do Homem (EMRK). ${ }^{159}$ Por seu turno, o direito alemão prevê poderes preventivos policiais para uma detenção bastante limitada de "pessoas perigosas" (como os torcedores hooligans do futebol), aplicável apenas em casos bem específicos. ${ }^{160}$ No entanto, o Ministério da Justiça alemão está considerando, atualmente, uma solução jurídico-penal para essa problemática: a ampliação do § 129a StGB, o que poderia possibilitar também uma ação preventiva contra determinados suspeitos de terrorismo, por meio de novos tipos penais no momento anterior ao crime (como a conclusão de formação para o terrorismo em um correspondente local de treino), juntamente de poderes de intervenção processuais penais já existentes (especialmente $\S 112$ Abs. 3 StPO). O potencial de manipulação de uma antecipação da punibilidade excessivamente ampla, motivada preventivamente pelo legislador, e o motivo de detenção por perigo de reincidência para delitos especiais atualmente já vigente ( $\$ 112 \mathrm{a}$ StPO) tornam nítido, todavia, problemas e perigos de uma tal “mudança do sistema”. ${ }^{161}$ Isso é reforçado quando pontos de aplicação de medidas são tipos penais antecipados e parcialmente indeterminados, como o $\S 129 \mathrm{a} \mathrm{StGB}$, que atualmente possibilita consideráveis intervenções processuais com objetivos preventivos. ${ }^{162}$ Uma vez que se sustenta que o caso de formação em um local de treinamento para terroristas constitui determinado interesse de prevenção, colocase ainda, no plano fático, a complicada questão: qual bem jurídico é ferido pelo fato 
incriminado e se uma correspondente antecipação da proteção do direito penal pode ser justificada. ${ }^{163} \mathrm{O}$ exemplo da estadia em um local de treinamento terrorista indica, assim, que o direito penal alemão vigente, no tocante às clássicas atividades de repressão e de proteção aos bens jurídicos, assim como seu princípio da culpa, sob o ponto de vista sistemático, não é a princípio o local ideal para fixar objetivos puramente preventivos.

Com isso, entretanto, permanece aberta a questão, se uma ligação de medidas preventivas de interferência intensa - ainda necessitada de melhor definição - com o direito penal, com sua vinculação a tipos penais ligados a fatos concretos, seus poderes de investigação e controle por um ministério público independente, pelo juiz natural e suas outras garantias para a proteção dos direitos de liberdade, não é mais adequado do que um direito policial clássico, que remonta a um conceito de perigo pouco preciso, limitado apenas pelo princípio da proporcionalidade e do juiz natural. Para além desse ponto, coloca-se a pergunta sobre uma "exportação" de garantias do direito penal para o direito policial ou outros ramos do "direito de segurança”. O instituto da medida de segurança após o cumprimento da pena mostra, com seus exigentes pressupostos, que também medidas exclusivamente preventivas contra "pessoas perigosas" podem ser reguladas com ligação às garantias penais, em uma "via" própria. ${ }^{164}$ Embora na prisão preventiva e em outras medidas de segurança haja renúncia ao princípio da culpa, a cumulação da vinculação qualificada ao tipo penal, das garantias de direito processual e das decisões judiciais prognósticas, no tocante a um perigo futuro, devem garantir melhor base de proteção do que as medidas preventivas de direito policial (entretanto, de menor intensidade de intrusão) podem alcançar.

O papel da prevenção no contexto do direito penal, assim como o papel do direito penal e de suas garantias no contexto do direito geral de segurança, ainda necessitam ser esclarecidos em diversos pontos. ${ }^{165} \mathrm{O}$ mesmo se aplica também à distinção entre o direito penal e o direito de guerra, que na Alemanha pressupõe um ataque atual e ilegal - questionável no caso de ataques a redes terroristas (internacionais) - de um inimigo externo armado, assim como para a interpretação do direito à legítima defesa do art. 51 do estatuto da ONU. ${ }^{166}$ A questão sobre a necessidade e o tipo de medidas preventivas no tocante aos riscos acima analisados e os pontos de vista dogmáticos e problemas de limitação mencionados comprovam, novamente, que o desenvolvimento jurídico de fato de formas de criminalidade complexas desafia o direito penal clássico nos seus fundamentos, e que os "limites do direito penal" pertencem às questões de pesquisa fundamentais no futuro. A permanente discussão sobre modificações cruciais do direito penal torna claro, para além disso, o quão importante é uma análise dos novos riscos, que possa ser comprovada empiricamente, das necessidades de proteção daí resultantes e das diversas formas de controle que possam ser utilizadas. 
c) Alternativas e suas avaliações: uma teoria dos limites do direito penal abrange, assim, além da limitação do mesmo em relação a outros conceitos do direito de segurança, a questão sobre as formas categoriais alternativas para reação a comportamentos desviados, sejam elas formais ou informais, o que gera outros questionamentos fundamentais concernentes à relação entre e o direcionamento de comportamentos por meio do direito penal e outras estratégias formais e informais de controle social, assim como em relação à "privatização" do direito de segurança. As atuais pesquisas - principalmente sobre a criminalidade organizada - mostram que medidas de prevenção pró-ativas e extrajurídicas (como para a eliminação de causas de mercados ilegais da criminalidade organizada) podem ser não apenas muito mais efetivas do que medidas de direito penal, policial ou mesmo militares, mas também são freqüentemente menos agressivas em relação aos direitos de liberdade do indivíduo do que poderes de coação jurídicos. ${ }^{167}$ Por essa razão, a análise de tais medidas deve receber mais atenção do que vem ocorrendo até então.

\subsection{CONSEQüÊnCIAS E PONTOS CENTRAis DA PESQUisa}

O "panorama” da exposição feita até aqui mostra que os problemas na limitação territorial e funcional do direito penal apresentam causas comuns ou parecidas. Esses problemas baseiam-se em uma "mudança técnica, econômica e política da sociedade”, que ocorre em um contexto global. Tal mudança compreende não apenas criminalidade, riscos e a sua compreensão. Ela modifica também o "sistema de referência do direito público e teórico-jurídico fundamental” do direito penal. $\mathrm{Na}$ sociedade (mundial de risco), aparece, no lugar do relacionamento nacional bipolar entre cidadão e Estado (existente em um ordenamento jurídico "fechado", organizado hierarquicamente, com um único soberano e um direito penal claramente definido), diversos atores nacionais, supranacionais e internacionais, públicos e privados, em complexos sistemas com diversos níveis e formas jurídicas e sociais diversas de controle social, com diversos subsistemas jurídicos, uma proteção de liberdades civis diversamente composta e com complexas relações de trocas. Essa mudança da sociedade, da criminalidade e do sistema de referência de direito penal desafia o direito penal clássico - baseado no território estatal e repressão - categorialmente e gera modificações fundamentais, especialmente no tocante aos seus "limites territoriais e funcionais".

As respostas às questões da pesquisa sobre os limites territoriais e funcionais do direito penal precisam, por isso, recorrer aos "fundamentos criminológicos, teóricojurídicos, de direito público e de direito penal”, caso pretendam desenvolver modelos esclarecedores sobre as funções e limites do direito penal na sociedade global de risco, assim como respostas aos novos desafios. Conceitos teóricos correspondentes podem, então, na pesquisa voltada para a aplicação prática, promover uma política criminal que não apenas é mais efetiva que a atual política, mas 
também fornece, tendo como base os direitos humanos vigentes universalmente, uma melhor proteção dos direitos de liberdade e a preservação de princípios de teoria do direito. As reações legais aos ataques de Nova Iorque, em 2001, e de Londres, em 2005, concebidas com pressão de prazo e de ações políticas nos EUA e na Inglaterra, mostram que tais questionamentos não podem ser respondidos apenas por políticos em discussões emotivas, após a ocorrência de crimes espetaculares, mas precisam, sim, ser estudados previamente pela ciência do direito.

O número e a complexidade de questionamentos, entretanto, não permitem uma resposta imediata ou teorias simples. Assim, é necessário refletir as abordagens metodológicas para responder às questões aqui colocadas e, especialmente, desenvolver métodos de pesquisa correspondentes ao presente programa.

\section{Métodos de PeSQUiSA E COORdenAÇÃo DE PESQUISA}

As questões fundamentais citadas e a sua ligação em uma abrangente proposta teórica sobre os limites territoriais e funcionais do direito penal na sociedade global de risco colocam, no tocante a métodos de pesquisa, principalmente, três tarefas. Primeiramente, devem ser determinados os métodos gerais de pesquisa para respostas às questões individuais aqui lançadas (3.1). Em seguida, deve-se tratar da questão de como o Instituto Max-Planck para direito penal estrangeiro e internacional de Friburgo deve coordenar as diversas pesquisas isoladas realizadas, em forma de projetos gerais, projetos individuais e teses, em relação aos complexos questionamentos já apresentados (3.2). A médio e longo prazos, a realização do programa de pesquisa exige ainda uma correspondente formação e inclusão de jovens cientistas (3.3).

\section{I MÉTOdos gerais de PeSQUisa}

Os métodos gerais para responder às questões aqui levantadas são determinados, sobretudo, por meio de diversos questionamentos empíricos, normativos e jurídicopolíticos do novo programa de pesquisa.

\section{I. I TÉCNICAS DE PESQUISA EMPÍRICAS NAS CIÊNCIAS SOCIAIS}

Para análise da formas de delito relevantes, da efetividade de medidas de direito penal, dos motivos para determinadas reações de atores políticos e de outros "questionamentos criminológicos” do programa de pesquisa são necessárias, inicialmente, as técnicas de pesquisa empírica das ciências sociais. ${ }^{168}$ Estes são os métodos de trabalho centrais do grupo de pesquisa de criminologia do Instituto, com o qual deve-se trabalhar conjuntamente em congruência com o objetivo do fundador do instituto Hans-Heinrich Jescheck, pela ligação do "Direito penal e criminologia sob o mesmo teto" ("Strafrecht und Kriminologie unter einem Dach"). ${ }^{169}$ Nesse contexto, devem ser desenvolvidos ainda mais os métodos que fornecem 
informações sobre as reações da população e dos atores políticos a novos riscos de segurança. ${ }^{170}$ Além disso, também os métodos de avaliação de conceitos de política criminal adquirem importância central. ${ }^{171}$

\section{I. 2 Dogmática de direito penal e Ciência universal do direito penal}

A dogmática do direito constitui o requisito para a análise de questionamentos normativos. Para o presente programa de pesquisa, por exemplo, ela tem importância quando as categorias e os subsistemas do direito de segurança (penal e extrapenal) em desenvolvimento têm de ser determinados ${ }^{172}$. No direito penal nacional clássico (especialmente alemão), a "dogmática de direito penal” contribui - em especial na formação jurídica -, há muito tempo, para a justiça, a segurança do direito, a igualdade jurídica e racional motivação jurídica, por meio de ordem sistemática, construção de conceitos, interpretação, reflexão metodológica e determinação dos valores a serem protegidos. ${ }^{173} \mathrm{O}$ mesmo deve valer também para o direito supranacional e internacional, que se desenvolve atualmente sob forte influência da common law. A “dogmática de direito penal européia” em criação se caracterizará, porém, por maior abertura metodológica e maior importância ao pensamento a partir de problemas do que a dogmática do direito penal alemã. ${ }^{174} \mathrm{O}$ direito supranacional e internacional levanta novos questionamentos metodológicos como quando o direito internacional penal ou o direito europeu são determinados, respectivamente, por meio de princípios jurídicos gerais e por meio de direito comparado valorativo. ${ }^{175}$

A construção de sistemas, de conceitos e determinação de valores fundamentais como métodos centrais da dogmática do direito penal não pode, entretanto, limitar-se ao direito vigente e ao seu desenvolvimento. Esses métodos e a sua referência ao sistema de direito penal possibilitam também a obtenção de conhecimentos de abrangência e validade mundiais e gerais para questionamentos comparáveis internacionalmente. ${ }^{176} \mathrm{O}$ desenvolvimento de uma tal "ciência jurídico-penal universal", de uma "gramática internacional do direito penal" ou de um "sistema de direito penal comum europeu” pressupõe, todavia, que sejam identificados e comparados, inicialmente, problemas e estruturas de um “metanível” dos ordenamentos jurídicos nacionais e que um conceito científico seja desenvolvido com base em tais fundamentos. ${ }^{177}$ A ciência do direito penal daí desenvolvida não permanece, por isso, no direito positivo, muito menos objetiva a exportação do próprio direito nacional, e sim visa à obtenção de soluções válidas genericamente, por meio da comunidade internacional de cientistas do direito penal. ${ }^{178}$ Tal ciência do direito penal universal serve tanto para a dogmática de direito penal do direito nacional e internacional vigente, como também para a respectiva reforma do direito penal. ${ }^{179}$ Fundamento de uma ciência do direito penal universal é, além dos métodos de dogmática do direito, especialmente, o direito penal comparado e a comparação de sistemas de direito penal. 
3.i.3 Direito penal comparado E ComparaÇÃo de Sistemas Com DiVERSOS Níveis a) $\mathrm{O}$ contexto global do presente programa de pesquisa, sua contribuição para o desenvolvimento de uma ciência internacional de direito penal e sua "estipulação de objetivos político-jurídicos" internacionais têm como efeito na realização do programa de pesquisa a fundamental importância do direito penal comparado e do método de pesquisa ${ }^{180}$ comparado.

O direito comparado é necessário, primeiramente, para o "levantamento de dados e análise do desenvolvimento jurídico atual”: uma vez que o direito penal e o direito sancionatório são regulados em diversos sistemas e ordenamentos jurídicos distintos - nacionais e internacionais -, somente o levantamento e a comparação de dados internacionais pode dar um panorama geral do desenvolvimento atual mundial e suas relações e fundamentos, mostrando seus perigos antecipadamente, como esta contribuição tenta fazer com uma primeira proposta. No futuro, tal levantamento de dados será necessário, especialmente para a avaliação do desenvolvimento do direito penal supranacional e nacional na União Européia, em que o princípio de confiança mútua precisa ser atendido não apenas para os países em processo de adesão, e sim por todos os Estados-membros constantemente. ${ }^{181}$ Mas a análise do direito vigente necessita do direito penal comparado também para o fechamento de lacunas do direito europeu, por meio de direito comparado e do direito internacional público, mediante a elaboração de princípios gerais do direito. ${ }^{182}$

Para o estabelecimento de objetivos de política criminal do novo programa de pesquisa, o direito penal comparado fornece, ademais, "novas idéias de soluções" tanto dentro como fora do direito penal e apóia uma política de good governance e do benchmarking de diferentes modelos de política criminal. A inclusão também de medidas externas ao direito penal e da comparação de métodos diversos, em direito comparado, oferece, da mesma forma, a possibilidade de superação do atual modelo de repressão e endurecimento de penas no processo de harmonização internacional do direito penal. Ela é também o fundamento metodológico para a harmonização jurídica, condição necessária para maiores campos da política criminal e modelos de cooperação que funcionem para a superação dos limites territoriais do direito penal.

O direito penal comparado pode, assim - em sua forma de direito penal comparado de comparação de valores e base de valores -, oferecer propostas de soluções para o fundamental problema de "valoração de toda política criminal científica”. Tal problema de valoração consiste em que a política criminal freqüentemente dependa de valorações básicas, que não são mais comprováveis cientificamente, mas precisam ser aceitas como decisões valorativas subjetivas. Partindo-se de valores básicos com alto grau de abstração, como a liberdade das pessoas em uma sociedade aberta ${ }^{183}$ ou de direitos humanos, é possível alargar o campo dos resultados racionais, em peroração dos dogmas inquestionáveis. Um direito penal comparado metodologicamente assegurado pode ainda, especialmente 
por isso, prestar uma contribuição própria, uma vez que mostra as possíveis alternativas na aceitação de valores fundamentais, variações e exclusões, permitindo uma reflexão própria permanente. ${ }^{184}$ Tais valores fundamentais e os métodos da dogmática jurídica proporcionam, assim, juntamente com a provisão de soluções internacionais de direito comparado e da avaliação criminológica das diferentes soluções, os fundamentos para sugestões de política criminal.

b) Comparação pressupõe, porém, tipos "legais comparáveis”, o que não só é problemático no direito penal comparado entre sistemas jurídicos com valorações básicas com diferenças fundamentais, mas também na comparação entre tais ordenamentos jurídicos e subordenamentos jurídicos de diferentes naturezas em "sistemas com diversos níveis”. Fundamentos do Estado nacional (como o princípio da democracia) não podem ser transferidos, sem motivação extra, em sistemas de níveis diversos, de uma ordem nacional para uma supranacional ou privada. ${ }^{185}$ A comparação de sistemas de diferentes naturezas (por exemplo, nacional, internacional ou privada), assim como, em especial, a pesquisa de direito penal internacional e supranacional, requer, em princípio, uma análise da estrutura dos respectivos ordenamentos, a averiguação de seus princípios políticos e jurídicos (de direito internacional público), assim como a identificação de valores vigentes em geral e em todos os sistemas de ordenamentos, que se encontram especialmente nos direitos humanos. ${ }^{186}$ Questões de teoria do direito, teoria do Estado, organização do Estado, direito internacional público, direito europeu e direitos humanos têm, assim, grande importância para a análise e comparação entre e no interior de sistemas jurídicos (penais) internacionais e supranacionais.

Tais questionamentos esclarecem que o direito penal comparado para o presente programa de pesquisa não pode ser apenas um método de pesquisa, mas também um objeto de pesquisa central. Para isso, é necessário o desenvolvimento de uma teoria do direito penal comparado, que combine, especialmente, pressupostos, métodos e capacidade de ação do direito penal comparado. ${ }^{187}$

\subsection{CONCEPÇÃo E COORDENAÇÃo dos PROJETOS DE PESQUISA}

\subsection{ObJetivos da COORdenAÇÃo DE PESQUisa}

O novo programa de pesquisa do departamento de direito penal ultrapassa programas de pesquisa isolados não apenas por sua abrangência e pela complexidade de seus questionamentos, mas também em relação ao número de participantes, doutorandos e pesquisadores visitantes. A pesquisa de fundamentos objetivada com esses projetos no Instituto Max-Planck não pode ter como objeto, segundo sua identidade, uma concatenação de projetos individuais isolados, devendo alcançar uma "mais-valia" que ultrapasse a soma dos projetos individuais. ${ }^{188}$ A concepção e conciliação dos 
projetos de pesquisa isolados realizados no Instituto Max-Planck de direito penal estrangeiro internacional de Friburgo na forma de projetos gerais e individuais (especialmente as numerosas teses) têm, portanto, importância central para a realização do programa de pesquisa.

\subsubsection{ConcentraçÃo dos Questionamentos em Áreas Centrais De Pesquisa}

A necessária coordenação de um grande número de projetos será efetuada no programa de pesquisa, por meio da "formação de três grandes áreas de pesquisa e diversos campos de pesquisa”, os quais possuem particular importância para os questionamentos aqui suscitados sobre os limites territoriais e funcionais do direito penal. As áreas de pesquisa correspondem amplamente, no nível organizacional do Instituto, aos respectivos relatórios por países e matéria, nos quais os conhecimentos especializados dessas matérias específicas são cultivados.

- Em virtude da especial importância do direito penal comparado para a aplicação do programa apresentado, tem-se no "direito penal comparado", como "método central”, a primeira grande área de pesquisa com um campo de pesquisa especial.

- Em uma segunda área de pesquisa, outros campos de pesquisa serão criados com intuito de “ordenamentos jurídicos e sistemas jurídicos” supranacionais e internacionais, em que as acima citadas questões de pesquisa sobre os limites territoriais e funcionais são especialmente relevantes, ou seja, no "direito penal europeu" e no "direito internacional penal". Em relação ao entrosamento dos sistemas com diversos níveis existentes, tem-se como outro campo de pesquisa a área da clássica "cooperação jurídica e das novas formas de cooperação internacional”.

- Uma concentração dos questionamentos e projetos de pesquisa expostos ocorre não apenas em relação a sistemas jurídicos relevantes, mas também em relação a "determinados campos de delinqüência", em que os problemas fundamentais citados são especialmente pungentes, o que vale para os problemas aqui tratados, particularmente nos campos de pesquisa do "mau uso da internet", assim como os "riscos" globais "da medicina e outras life sciences". ${ }^{189}$ Também são incluídas outras formas de "crimes complexos", como crimes econômicos, criminalidade organizada e terrorismo, em que os "limites do direito penal" se mostram de modo particularmente nítido. ${ }^{190}$

Essas áreas e campos de pesquisa, assim como os questionamentos atualmente tratados devem ser apresentados em seguida, com base em novos projetos de pesquisa, que puderam ser iniciados no Instituto, especialmente a partir de 2005. ${ }^{191}$

\subsubsection{CAmpos de PeSquisa e PRojetos De Pesquisa}

a) Direito penal comparado: o direito penal comparado é, em virtude de sua grande importância para o questionamento jurídico global, não apenas o "método de pesquisa 
fundamental" para a aplicação do novo programa de pesquisa, mas também, ele próprio, "objeto central de pesquisa". Por isso, objetivos, tarefas e métodos do direito penal comparado formam, assim, um ponto central de pesquisa e um campo de pesquisa relevante, em que os respectivos resultados individuais do Instituto devem continuar sendo desenvolvidos para a citada teoria do direito penal comparado. Tarefas, métodos e propostas de teoria do direito penal comparado também estavam, assim, no começo dos novos trabalhos de pesquisa no Instituto de Friburgo nos últimos dois anos. De especial importância para a realização prática do programa de pesquisa em questão são os métodos de direito penal comparado, principalmente a comparação de direito penal utilizando os métodos universal, funcional, sistemático, casuístico, comparativo de valores e apoiado em computadores. ${ }^{192}$

Para a continuação do desenvolvimento do direito penal comparado é necessário - especialmente também para fins de pesquisa dos fundamentos de direito comparado - um banco de dados dos diversos ordenamentos jurídicos nacionais e internacionais, ${ }^{193}$ não apenas no tocante às "questões metodológicas" do direito penal comparado, mas serve também para diversos projetos futuros, como pedra fundamental de conhecimento do direito penal nacional e internacional. Tais necessidades de conhecimento dos fundamentos devem ser satisfeitas por meio do desenvolvimento de um banco de dados e de um sistema eletrônico específico ${ }^{194}$. O objetivo de um projeto de pesquisa a longo prazo é, assim, a concepção de um sistema de informações sobre um fundamento assegurado metodológica e teoricamente, a construção de um respectivo protótipo de parte geral do direito penal, o desenvolvimento de uma comparação transversal sistemática das questões jurídicas relevantes e da conseqüente evolução contínua dos métodos de direito penal comparado. Esse projeto de programa de pesquisa - fundamental e a longo prazo - deve ser entendido também como resposta à reivindicação de Claus Roxin, de 1999, que descreveu uma apresentação geral do direito penal de todos os Estados europeus e dos mais importantes Estados não-europeus como "tarefa futura da ciência mundial do direito penal". 195

O projeto de pesquisa é, assim, também uma contribuição à supracitada ciência universal do direito penal e ao distante objetivo, formulado há mais de um século por Franz von Liszt, de uma "teoria geral de direito penal" sobre fundamentos de direito comparado. ${ }^{196}$ Por isso, no centro das pesquisas atualmente desenvolvidas, está a análise de uma metaestrutura universal dos problemas e regras pertinentes, necessária como fundamento de uma ciência universal do direito penal, para que se possam comparar regulamentações diferentes mundialmente. Um projeto como esse promete, ainda, um ganho adicional para o intercâmbio crítico com cientistas estrangeiros, quando o sistema do Instituto de Friburgo estiver à disposição na internet como "ponte para o mundo" com a sua estrutura de informática. ${ }^{197}$ Juntamente com outros projetos sobre o direito penal comparado e estrangeiro, ${ }^{198}$ iniciados após a 
sucessão da diretoria, o trabalho nesse projeto já conduziu a novos conhecimentos sobre os métodos de direito penal comparado. ${ }^{199}$

b) Sistemas jurídicos internacionais: para os questionamentos deste programa de pesquisa, têm importância especialmente os ordenamentos jurídicos supranacionais e internacionais, além do direito estrangeiro - no contexto do direito comparado -, e questões de cooperação jurídica e outras formas de cooperação em sistemas com diversos níveis.

aa) O complexo "direito penal europeu” (da União Européia, mas também do Conselho da Europa) é interessante para o novo programa de pesquisa, especialmente em relação aos limites territoriais do direito penal e particularmente no tocante aos seus modelos de cooperação entre os sistemas de direito penal. ${ }^{200}$

Por isso, o objetivo de pesquisa de um projeto maior sobre o direito penal europeu é o desenvolvimento de modelos para uma futura persecução penal européia, assim como de princípios correspondentes de solução para outros problemas políticos e econômicos. Inicialmente, o projeto de pesquisa compara e valora, por meio do direito comparado, diversos modelos de cooperação federais e supranacionais de ordenamentos jurídico-penais. Merecem especial atenção o processo de harmonização do direito penal de modelos de solução supranacionais e o princípio de reconhecimento mútuo de decisões em modelos de cooperação. ${ }^{201}$ Por meio da inclusão de outros ordenamentos de direito penal (também mais centralistas), devem ainda ser identificados princípios fundamentais e princípios jurídicos comuns da administração da justiça penal nacional européia, que também podem ser cumpridos por modelos de solução supranacionais e cooperativos ou ser transferidos a estes de maneira modificada. Os dispositivos assistemáticos de direito penal no projeto de Constituição Européia, assim como a discussão em torno do mandado europeu de prisão e do mandado europeu de obtenção de provas, tornam claro que um tal trabalho de base conceitual é pressuposto para uma futura política criminal européia. Esse trabalho de base para a integração de sistemas de direito penal é apoiado por outros projetos e teses sobre o mandado europeu de prisão e sobre o princípio do reconhecimento mútuo no direito de provas. ${ }^{202}$

bb) A importância do "direito internacional penal" 203 para o programa de pesquisa reside inicialmente, também em sua função de modelo para a unificação de ordenamentos de direito penal nacionais, na regulamentação e persecução de determinados crimes contra a humanidade. Após a conclusão de um projeto de pesquisa, que está sendo executado no Instituto há alguns anos, sobre a comparação das regulamentações nacionais do direito internacional penal, ${ }^{204}$ serão analisados especialmente os processos de criação de um ordenamento jurídico mundialmente vigente.

Um projeto maior trata do desenvolvimento de princípios gerais do direito internacional penal, a exemplo da participação no ato penal, especialmente na constelação 
relevante para o direito internacional penal da "criminalidade dos líderes em grupos ou redes de criminosos”. Por meio da comparação das normas de participação sob particular consideração da figura do joint criminal enterprise, importante para o direito internacional penal, o projeto fornece simultaneamente conhecimento quanto à questão central da pesquisa relativamente aos limites funcionais do direito penal na imputação de comportamento alheio. A pesquisa realiza-se no âmbito do citado sistema de informação do Max-Planck de direito penal comparado e constitui, a exemplo de uma complexa problemática de direito comparado, com a inclusão de mais de 40 ordenamentos jurídicos simultaneamente, também um primeiro teste para esse projeto e para o desenvolvimento de uma teoria de direito penal comparado a ele relacionado. 205

Semelhantes objetivos teve o projeto sobre cálculo da pena no direito internacional penal, finalizado em 2004. ${ }^{206}$ Um outro projeto de direito internacional penal trata, a exemplo do estudo do extermínio da população em Ruanda, de questões do paralelismo de diversos ordenamentos jurídicos nacionais e regulamentos internacionais. ${ }^{207}$ Esses projetos sobre direito internacional penal constituem, juntamente com as pesquisas sobre o direito penal europeu e dos trabalhos citados abaixo, de direito penal de informação, as primeiras peças para a compreensão teórica das questões quanto aos limites territoriais do direito penal na sociedade global de risco e para o desenvolvimento de modelos de um direito penal transnacional efetivo.

cc) A “cooperação internacional” de diferentes ordenamentos jurídicos nacionais com o objetivo de um direito penal eficaz em nível transnacional dá-se, classicamente, mediante a cooperação administrativa e jurídica. As supracitadas modificações atuais da globalização, entretanto, levam a modificações sensíveis de tais institutos, assim como à complementação destes por meio de novas formas de cooperação. Essas modificações referem-se, de um lado, a novos mecanismos para a facilicitação da cooperação jurídica, como o reconhecimento imediato de decisões e a disponibilização de dados. De outro lado, criam-se novas formas de trabalho conjunto em task forces internacionais e instituições, que, em parte, conduzem a complexos sistemas com diversos níveis.

Por esse motivo, o Instituto participou, em 2006, de uma conferência germanoamericana sobre a questão do trabalho conjunto germano-americano no campo do terrorismo. Em complemento ao supracitado projeto de pesquisa sobre as formas de cooperação no direito penal para o futuro direito penal europeu, um outro projeto, com início em 2007, tratará, sobretudo, da criação e da influência sobre o direito penal material como parte integrante das novas formas de cooperação internacional e analisará os pressupostos de legitimação deste.

c) Áreas centrais de delinqüência: a análise dos questionamentos do presente programa de pesquisa ocorre não apenas de modo abstrato e geral, mas também nos problemas 
concretos em áreas de delinqüência pertinentes, nas quais se colocam de maneira particularmente clara as questões sobre os limites territoriais e funcionais, podendo ser resumidos com o conceito de "criminalidade complexa".

a) De particular interesse são o Cybercrime 208 e o "direito de internet"209 correspondente, tanto em relação aos limites territoriais quanto funcionais do direito penal. Como analisado anteriormente, a transmissão de dados em redes de computadores internacionais leva à dissolução das categorias clássicas de lugar e tempo, conduzindo assim a um protótipo de criminalidade transnacional, que se caracteriza por uma grande ubiqüidade, grandes riscos e especial complexidade.

As pesquisas sobre Cybercrime e direito penal de informação, portanto, se iniciam com uma análise da delinqüência complexa pertinente, seu objeto - caracterizado pela qualidade imaterial da informação - e seus riscos específicos. Sobre esta base, são pesquisadas, então, as possibilidades e os limites de um controle nacional e internacional de criminalidade transnacional em um ambiente técnico complexo, o que ocorre em uma série de análises individuais. O "potencial de poder e vigilância”, em virtude da disponibilidade de dados pessoais, é de interesse tanto sob o aspecto de novos riscos quanto também com intuito de novas medidas de investigação na internet. Um projeto sobre a anonimidade na internet trata da ponderação entre a necessária vigilância na internet e o direito de autodeterminação de se informar em espaços livres de controle. Outros trabalhos sobre as perspectivas de sucesso de medidas nacionais de proteção e isolamento na internet, sobre a aplicação extraterritoral do direito penal, assim como sobre o desenvolvimento de medidas alternativas do controle social, fornecem resultados importantes para os limites territoriais e funcionais do direito penal. ${ }^{210}$ Nesse aspecto, surgem pontos de contato com o grupo de pesquisas criminológicas do Instituto, sobretudo com a sua área de concentração de pesquisa sobre a análise empírica do processo penal. ${ }^{211}$

bb) Os "riscos globais da medicina, da biotecnologia e das outras life sciences", no contexto do novo programa de pesquisa, são interessantes, não só com vistas aos limites territoriais do direito penal, por exemplo, no tocante às diferentes questões valorativas internacionais, a fuga para outros ordenamentos jurídicos (como na pesquisa com embriões in vitro) ${ }^{212}$ e no tratamento do dissenso internacional sobre medidas de valoração fundamentais. Nesse campo, podem ser adquiridos também conhecimentos sobre os novos riscos e limites funcionais do direito penal, especialmente em virtude dos métodos alternativos de controle de risco praticados nesse contexto. Como exemplos podem ser citados a divisão de tarefas entre esporte e Estado na luta contra o doping, a autodefesa da indústria contra a falsificação de medicamentos, a reorientação do controle jurídico e da verificação posterior no processo penal para uma inspeção prévia pericial para a garantia da qualidade, as exigências de autorização administrativa ou judicial, assim como comissões éticas particulares e estatais para a avaliação de intervenções 
médicas "limítrofes" (incluindo testes clínicos de medicamentos, cada vez mais internacionalizados) e o impedimento do abuso de "produtos de dual use" da biotecnologia por meio de codes of ethics e codes of conduct dos cientistas participantes. ${ }^{213}$ Por isso, a longo prazo, o tradicional departamento de direito de medicina ${ }^{214}$ do Instituto será direcionado mais acentuadamente aos novos riscos das life sciences e às possibilidades do controle destes. ${ }^{215}$

Após a conclusão de um projeto em curso no Instituto sobre o status do embrião, ${ }^{216}$ deverá ser iniciado, paralelamente a uma pesquisa sobre falsificação de medicamentos, um trabalho de pesquisa sobre as estratégias alternativas de controle no campo da medicina e outras life sciences. Considerando os novos riscos das life sciences, as possibilidades especiais de um controle dos riscos de pesquisa por meio de codes of conduct não serão examinadas no âmbito de um projeto de pesquisa, mas em um grupo de trabalho da Max-Planck Gesellschaft voltado à prática com o objetivo de desenvolver um code of conduct para a sua própria pesquisa. Essas medidas de controle alternativas podem ser investigadas, sistematizadas e valoradas por meio do direito comparado. Os conhecimentos assim adquiridos deverão complementar conhecimentos correspondentes, porém, com uma ênfase mais técnica na área do Cybercrime e, assim - com uma mais-valia para as pesquisas das diversas áreas delitivas -, possibilitar uma sistemática e valoração de medidas alternativas do controle social.

cc) As questões centrais levantadas pelo programa de pesquisa sobre os "limites do direito penal" colocam-se também em "outras áreas de criminalidade complexa", principalmente no campo da criminalidade econômica, da criminalidade organizada e do terrorismo. Isso vale tanto para a já analisada "desfronteirização do direito penal”, assim como para as medidas de controle alternativas, de grande importância no campo do programa de pesquisa.

No foco das pesquisas pertinentes sobre os limites do direito penal estará um projeto de pesquisa sobre o terrorismo. Ali serão analisados, comparados e avaliados, em diversos ordenamentos jurídicos, principalmente as causas e os feitos da legislação sobre o terrorismo, quanto às suas intervenções em direitos de liberdade. Essas pesquisas farão parte de um planejamento de projeto interdisciplinar maior, em cooperação com o grupo de pesquisa de criminologia do Instituto e de outros Institutos Max-Planck e seus parceiros europeus. ${ }^{217}$ Com isso, deverão ser viabilizadas respostas à pergunta sobre em que medida a atividade legiferante é influenciada por aumentos de riscos objetivos ou por expectativas subjetivas da opinião pública e/ou dos atores políticos. Esse projeto constitui, juntamente com teses isoladas sobre o terrorismo, os chamados projetos relativos aos riscos da internet e das life sciences, assim como com outros projetos, ${ }^{218}$ as primeiras peças para a supracitada teoria sobre os limites funcionais do direito penal na sociedade global de risco. 


\subsection{International Max-Planck Research School for Comparative Criminal Law}

A realização exitosa do programa de pesquisa exige, a médio e longo prazos, também sua ligação com uma correspondente formação de jovens cientistas. A esta formação destina-se a Max-Planck Research School for Comparative Criminal Law, iniciada em março de 2007.219 A Research School é operada pelo departamento de direito penal do Instituto, em cooperação com o seu departamento de criminologia e da Faculdade de Direito da Universidade Albert Ludwig de Friburgo. O objetivo são teses de doutorado com temas comparatísticos e baseados ou relacionados com o direito comparado - também no contexto de outros trabalhos da Research School -, especialmente, com vistas a questionamentos do novo programa de pesquisa sobre os limites do direito penal. Ponto focal do interesse da pesquisa são - com a inclusão de áreas de concentração de outras instituições e professores participantes - a harmonização e internacionalização do direito penal, assim como sua institucionalização internacional e limites. Temas centrais são a criminalidade complexa (e as áreas da criminalidade da internet e do terrorismo), a identificação da criminalidade, o desenvolvimento da criminalidade e dos discursos sobre criminalidade, assim como os questionamentos de direito comparado nos campos da história do direito penal e da percepção da gravidade de delitos. Se, com isso, questões fundamentais comuns do programa de pesquisa relacionarem os diversos projetos e teses do Instituto e se no seminário comum da Research School forem desenvolvidos, isso poderá gerar efeitos de sinergia adicionais e novos conhecimentos, não apenas para os trabalhos isolados, mas também para o programa de pesquisa aqui apresentado como um todo e para seus questionamentos interdisciplinares. A formação específica de jovens pesquisadores nos campos de pesquisa apresentados promoverá sensivelmente o programa de pesquisa a longo prazo.

\section{Resumo}

1. O departamento de pesquisa de direito penal do Instituto Max-Planck de direito penal estrangeiro e internacional de Friburgo continua, depois da troca de diretores, a mesma orientação do Instituto, fundada por Hans-Heinrich Jescheck e Günther Kaiser, e seguida pelos seus sucessores Albin Eser e Hans-Jörg Albrecht, que prega uma ligação entre os grupos de pesquisa de criminologia e de direito penal "sob um mesmo teto", assim como do direito penal comparado como método fundamental. 220 Inédito é que a pesquisa e a International Max-Planck Research School for Comparative Criminal Law, fundada no Instituto em 2007, desenvolvem-se pela primeira vez no contexto de um "programa de pesquisa transparente e a longo prazo". Esse programa corresponde às crescentes exigências requeridas hoje pela competição internacional da pesquisa na Max-Planck Gesellschaft: com seus focos e campos de pesquisa, concentra o trabalho em importantes questões do 
futuro, fomenta a análise de questões fundamentais, abordagens teóricas e questões metodológicas, apóia os jovens pesquisadores e leva, especialmente, a uma maisvalia que ultrapassa as questões isoladas.

2. O novo programa de pesquisa tem três "objetivos de pesquisa" gerais, cada qual constituindo a base para o seguinte: (a) a análise das modificações "reais" da delinqüência e dos riscos de segurança na sociedade cunhada por globalização e pela transformação técnica e econômica; (b) a análise e avaliação crítica das respectivas modificações "normativas" no direito penal vigente e na prática do direito; e (c) o desenvolvimento de respostas às atuais e futuras questões de "política criminal" sobre tais modificações.

Em relação a esses objetivos de pesquisa, esta contribuição analisou as atuais modificações da sociedade, do desenvolvimento da criminalidade e do direito penal como fundamento para uma especificação das questões de pesquisa. Ponto de partida da análise foram as modificações sociais caracterizadas pelos conceitos de "sociedade mundial", "sociedade de informação" e "sociedade de risco" e, assim, examinados mais detalhadamente. Com essas modificações, surgem hoje "novos desafios ao direito penal”, caracterizados por uma criminalidade transnacional crescente, assim como por um considerável potencial de risco e elevada complexidade.

A crescente "criminalidade transnacional" baseia-se principalmente nas modificações técnicas, econômicas e políticas da globalização, que proporcionam novas oportunidades para o cometimento de crimes que ultrapassam fronteiras, por exemplo, em redes internacionais de dados e mercados ilegais globais. Essas novas oportunidades de criminalidade transnacional desafiam os "limites territoriais" do direito penal nacional, uma vez que muito dificilmente pode ser imposto em face da criminalidade transnacional, quando a validade de suas decisões em outros territórios demanda, primeiramente, processos administrativos e judiciários demorados e os ordenamentos penais nacionais divergem entre si. Por isso, esses limites territoriais e as possibilidades de sua superação com um "direito penal transnacional eficaz" representam um primeiro foco das futuras pesquisas, que objetiva uma teoria de integração de direito penal internacional.

Acompanham a transformação técnica, econômica e política, ainda, "riscos aumentados", uma criminalidade de crescente "complexidade" e especiais dificuldades de esclarecimento, como se observa em estruturas criminosas, baseadas em divisão de trabalho internacional organizada, assim como no uso de nova técnica na prática do crime. Os riscos crescentes se mostram, especialmente, no campo dos delitos do terrorismo, da criminalidade organizada, da criminalidade econômica, da criminalidade na internet, assim como nos possíveis abusos das life sciences. Esse processo é fortalecido pela perda de controle do Estado nacional clássico, no contexto da globalização, que os Estados nacionais tentam compensar atualmente por meio de 
novas redes de cooperação internacional, medidas técnicas de vigilância, um novo “direito de segurança”, orientado pelos princípios da prevenção, deveres de participação de particulares, assim como medidas alternativas de controle social. Essas modificações levam o direito penal clássico, em suas funções de garantia de proteção da sociedade e da liberdade do indivíduo, a seus "limites funcionais". O desenvolvimento dos fundamentos teóricos e práticos aqui analisados sobre os limites funcionais do direito penal, assim como as questões resultantes sobre o "direito de prevenção e segurança" e as medidas alternativas de controle social representam, por isso, um segundo ponto central da pesquisa.

Em ambas as áreas de concentração, resultam perguntas fundamentais iguais, similares ou estreitamente relacionadas, por exemplo, sobre as modificações do direito penal em virtude do complemento da relação bipolar entre o cidadão e o Estado nacional clássico, por meio de “complexos sistemas com diversos níveis" e, em parte, internamente contraditórios e concorrentes com numerosos atores nacionais, supranacionais e particulares, assim como da resultante fragmentação do direito na sociedade de risco mundial.

3. O departamento de pesquisa de direito penal analisa essas modificações mundiais da criminalidade e do controle da criminalidade no plano fático, normativo e político-jurídico, principalmente com o objetivo de uma melhoria da política criminal. "Métodos de pesquisa" centrais para atingir os fins pretendidos são, assim, além dos métodos - primariamente empregados pelo grupo de pesquisa criminológica - de pesquisa social empírica, a inclusão de questões fundamentais de teoria do direito, direito internacional público, direito europeu e direitos humanos, para a determinação dos quadros de referência de direito penal dos novos sistemas com diversos níveis. Especial importância possuem, então, os métodos da dogmática jurídica, a participação em uma ciência de direito penal internacional e o direito penal comparado. O direito penal comparado é, assim, no presente programa não apenas o método de pesquisa, mas, sim, ele próprio, um objeto central da pesquisa.

4. O Instituto Max-Planck de direito penal estrangeiro e internacional de Friburgo segue, assim, diante das modificadas condições da sociedade no século XXI, o caminho traçado pelo Prof. Dr. Hans-Heinrich Jescheck com sua aula inaugural de $1954^{221}$ e com a fundação do Instituto em 1977. Para satisfação do autor, assim como dos colaboradores e visitantes do Instituto, Hans-Heinrich Jescheck continua participando ativamente do desenvolvimento do Instituto, e está em atividade lá regularmente. Este artigo é dedicado a ele, pelo seu 92. ${ }^{\circ}$ aniversário, em 10.01.2007. Ad multos annos!

Publicação original: $Z S t W$ v. 119 (2007), p. 1 e ss. 


\section{NOTAS}

* Dedicado ao fundador do Instituto Max-Planck de Friburgo, Prof. Dr. Dr. h.c. mult. Hans-Heinrich Jescheck, pelo seu $92 .^{\circ}$ aniversário, em 10 de janeiro de 2007.

1 Cf. Sieber, Grenzen des Strafrechts, in: Albrecht/Sieber (Coord.), Perspektiven der strafrechtlichen Forschung, Amtswechsel am Freiburger Max-Planck-Institut für ausländisches und internationales Strafrecht 2004, 2006, p. 35-79. Agradeço ao meu colaborador, Sr. Jan-Michael Simon, pelo apoio na publicação do programa de pesquisa.

2 O objetivo dessa construção teórica é a explicação sistemática de procedimentos por meio da organização dos conhecimentos em um contexto geral, ou seja, um sistema de proposições articulado por critérios de organização e unidade. Cf. Canaris, JZ 1993, 377-391 (377 e s.); Dreier, Recht-Moral-Ideologie, 1981, p. 70-105; Prim/Tilmann, Grundlagen einer kritisch-rationalen Sozialwissenschaft, 8. ed., 2000, p. 76-93. Sobre os axiomas e as valorações fundamentais, que servem de base à pesquisa e que, em parte, também são definidos como teorias, ver com uma consagração da pessoa e sua liberdade em uma sociedade aberta - Sieber, Strafrechtsvergleichung im Wandel, in: Sieber/Albrecht (Coord.), Strafrecht und Kriminologie unter einem Dach, 2006, p. 78-151 (121 e ss.). Sobre o objetivo de uma integração das capacidades de pesquisa no programa de pesquisa, cf. detalhadamente, abaixo, 3.2.1.

3 Cf. Beck, Das Schweigen der Wörter, Über Terror und Krieg, 2002, p. 10 e s. Mais detalhadamente sobre esses desenvolvimentos, ver infra, 2.2.1c e 2.2.2.a.ee e ff.

4 Uma pesquisa completa desses processos é de grande importância, principalmente porque modificações do desenvolvimento da criminalidade são, geralmente, um reflexo da mudança social, e o desenvolvimento do direito penal e da política criminal sempre são uma reação a essas modificações. Por isso, a orientação do programa de pesquisa às modificações sociais mantém o programa de pesquisa aberto para novos desenvolvimentos. Cf. sobre a relação entre direito penal e mudança social Hassemer/Neumann, in: Kindhäuser/Neumann/Paeffgen (Org.), Nomos Kommentar Strafgesetzbuch, 2. ed., 2005, Vor § 1 Rn. 330.

5 Cf. Beck, World Risk Society, Cambridge, 1999; Beck/Holzer, Wie global ist die Weltrisikogesellschaft?, in: Beck/Lau (Coord.), Entgrenzung und Entscheidung, 2004, p. 421-439.

6 Sobre a globalização da política criminal cf. Albrecht, JURA (Ungarn) 2005/2, 7-19 (11 f.); Karstedt, Criminal Justice 2002, p. 111-123; Sieber (nt. 2), in: Sieber/Albrecht (Coord.), p. 80-93.

7 Sobre as tarefas do direito penal na proteção da sociedade e da liberdade do indivíduo, cf. BVerfGE 70, 297, 307; 107, 104, 118 e s.; Hassemer, in: Griesbaum et al. (Coord.), Strafrecht und Justizgewährung, Festschrift für Kay Nehm zum 65. Geburtstag, 2006, p. 49-60 (59 e s.); Limbach, Die Demokratie und ihre Bürger, 2003, p. 93-113.

8 Cf. Beck (nt. 5); O’Rourke/Williamson, European Review of Economic History 6 (2002), 23-50; idem, European Review of Economic History 8 (2004), 109-117; von Bogdandy, ZaöRV 63 (2003), p. 853-877 (856 e ss.); Stiglitz, Die Chancen der Globalisierung, 2006; Streeck, in: Max-Planck-Gesellschaft (Coord.), Jahrbuch 2004, 2004, p. 25 -37 (28 e s.). Sobre um panorama das estruturas globais e seus direcionamentos do ponto de vista jurídico, econômico e social, ver os resultados do programa de incentivo da Fundação VW em Mayntz/von Bogdandy/Genschel/Lütz, Globale Strukturen und deren Steuerung, 2005. Sobre a globalização da política criminal, ver nt. 6.

9 Cf. Sieber, Verantwortlichkeit im Internet - Technische Kontrollmöglichkeiten und multimediale Regelungen, 1999, p. 96 e ss

10 Cf. sobre o estado atual o relatório do Financial Action Task Force, Money laundering and terrorist financing typologies 2004-2005, Paris 2005. Veja também Shams, Legal globalization, money laundering and other cases, London, 2004, especialmente p. 99 e ss., assim como os artigos in: Masciandaro (Coord.), Global financial crime: terrorism, money laundering and offshore centres, Aldershot 2004

11 Cf. sobre Global Container Control Pilot Programme, como medida de controle, United Nations Office on Drugs and Crime, Annual Report 2005, Wien 2005, p. 76. Com a Container Security Initiative foram tomadas precauções pelo U.S. Customs Service e pelas administrações dos portos em cerca de 50 cidades portuárias em todo o mundo, para poder 
identificar e examinar, já no local de embarque, containers perigosos ou suspeitos, cujo destino sejam os EUA; disponível em: <www.cbp.gov/xp/cgov/border_security/international_activities/csi/>. Acesso em: 18 dez. 2006.

12 Cf. sobre uma análise de casos de fraudes por meio de sociedades de seguro Off-shore: Tillmann, Global pirates: fraud in the offshore insurance industry, Boston, 2002, assim como Sieber, Transnational Enterprises and Criminal Law, in: Tiedemann (Coord.), Multinationale Unternehmen und Strafrecht, 1980, p. 155-175.

13 Cf. sobre o comércio internacional de pessoas International Organization for Migration, Data and Research on Human Trafficking: A Global Survey, Genf, 2005; sobre o comércio ilegal de drogas, United Nations Office on Drugs and Crime, World Drug Report 2005, New York, v. 1, p. 23-146, 2005; sobre comércio internacional ilegal de armas convencionais e de destruição em massa, Wezeman/Bromley, SIPRIYearbook 2005, Oxford et al., 2005, p. 417-448 (434 e ss.); sobre o mercado internacional de produtos falsificados e pirateados, cf. o projeto Bascap da câmara internacional de comércio: disponível em: <http://www.iccwbo.org/bascap>, acesso em: 18 dez. 2006; sobre o crescente comércio internacional de órgãos, o relatório do secretário-geral das Nações Unidas: Annan, Preventing, combating and punishing trafficking in human organs, Report of the Secretary-General, UN Doc. E/CN.15/2006/10, 21.02.2006, p. 13 e s., assim como Meyer, Trafficking in Human Organs in Europe, European Journal of Crime, Criminal Law and Criminal Justice, 2006, p. 208-229.

14 Cf. sobre esse contexto, por exemplo, o estudo de Gerber/Killias, European Journal of Crime, Criminal Law and Criminal Justice, 2003, p. 215-226.

15 Cf. sobre o chamado carrossel do Imposto sobre Valor Acrescido (Mehrwertsteuer), por último, as decisões do Tribunal de Justiça das Comunidades Européias (EuGH) nos casos Optigen Ltd. (C-354/03), Fulcrum Electronics Ltd. (C-355/03) e Bond House Systems Ltd. (C-484/03) v. Commissioners of Customs \& Excise, de 12.01.2006 (OJ C 74, 25.03.2006, p. 1), assim como o relatório annual de OLAF, Report of the European Anti-Fraud Office, Fifth Activity Report for the year ending June 2004 , p. 46 ss. e 50 e s.

16 Cf. para o comércio de pessoas Smartt, European Journal of Crime, Criminal Law and Criminal Justice, 2003, p. 164-177 (173 e s.). Pesquisas empíricas que comprovem tal relação ainda não foram realizadas. Entretanto, os resultados de pesquisas sobre logística do crime organizado na Alemanha sugerem tal relação para o território europeu; cf. sobre isso Sieber/Bögel, Logistik der Organisierten Kriminalität, 1993, p. 101 e ss.

17 Cf. a observação supra, nt. 15, assim como Sieber, SchweizStrZ, 1996, p. 357-395.

18 Cf. Sieber, Auf dem Weg zu einem europäischen Strafrecht, in: Delmas-Marty (Coord.), Corpus Juris der strafrechtlichen Regelungen zum Schutz der finanziellen Interessen der Europäischen Union, 1998, p. 1-10. Sobre os mais importantes tratados concernentes às relações de cooperação jurídica em matéria penal da Alemanha, recentemente: Schomburg, NJW, 2005, p. 3262-3266.

19 Cf., além da observação na nt. 18, especialmente Delmas-Marty, European Journal of Crime, Criminal Law and Criminal Justice, 2002, p. 286-293, além de idem, in: Collège de France (Coord.), Cours et travaux du Collège de France, Résumés 2003-2004, p. 695-720 (698 e ss.), e por último idem, Le relatif et l'universel, Paris, 2004, p. 241-307; Sieber, Auf dem Weg zu einem europäischen Strafrecht, in: Delmas-Marty (Coord.), Corpus Juris der strafrechtlichen Regelungen zum Schutz der finanziellen Interessen der Europäischen Union, 1998, p. 1-10.

20 Sobre as possíveis formas de cooperação entre sistemas de direito penal diferentes, Sieber, JZ 1997, p. 369381, assim como os artigos em: Instituto Nacional de Ciencias Penales/Max-Planck-Institut für ausländisches und internationales Strafrecht (Coord.), Hacia la unificación del derecho penal, Logros y desafíos de la armonización y homologación en México y el mundo, México, 2006.

21 Cf., sobre mandado de detenção europeu, o projeto de Decisão-Quadro do Conselho sobre o mandado de detenção europeu e o processo de entrega de presos entre Estados-membros 2002/584/JI de 13.6.2002, Abl. L 190, e Cartier (Coord.), Le mandat d'arrêt européen, Brüssel, 2005, assim como os artigos em: Max-Planck-Institut für ausländisches und internationales Strafrecht (Coord.), eucrim 2006, Heft 1/2 (www.mpicc.de/eucrim) e as observações especiais sobre a interpretação e aplicação alemã, infra nt. 35. Sobre o mandado europeu de obtenção de provas, ver o projeto de Decisão-Quadro do Conselho sobre o mandado europeu de obtenção de provas de coisas, escritos e dados, para uso em processos penais, KOM (2003) p. 688 endg., e, sobre isso, Ahlbrecht, NStZ 2006, p. 70-75; Gleß, 
StV 2004, p. 679-683, idem, ZStW 116 (2004), p. 353-367, assim como os artigos in Vervaele (Coord.), European Evidence Warrant, Transnational Judicial Inquiries in the EU, Antwerpen/Oxford, 2005. Sobre o reconhecimento de penas pecuniárias e multas, cf. a Decisão-Quadro 2005/214/JAI do Conselho, de 24.02.2005, Abl. L 76, sobre a aplicação do princípio de reconhecimento mútuo de penas pecuniárias e multas.

22 Cf. Kommission der Europäischen Gemeinschaften, Vorschlag für einen Rahmenbeschluss des Rates über den Austausch von Informationen nach dem Grundsatz der Verfügbarkeit, KOM (2005) 490 de 12.10.2005. Especialmente sobre a troca de dados policiais ver também Schily, in: Bundeskriminalamt (Coord.), Neue Allianzen gegen Kriminalität und Gewalt, 2006, p. 7-16 (9 e s.). Sobre a troca de dados e o banco de dados comum da Interpol, cf. Louboutin, ibidem, p. 101-122.

23 Sobre as sanções administrativas em nível europeu, cf. Tiedemann, ZStW 116 (2004), p. $945-958$ (946 e ss.); sobre as sanções à formação de cartel, cf. Harding, European Journal of Crime, Criminal Law and Criminal Justice 2004, p. 275-300; sobre os fundamentos do direito internacional penal, cf. Werle, Völkerstrafrecht, 2003, p. 1-92.

24 Cf. observações gerais na nt. 20. Sobre um modelo de harmonização das competências em matéria penal como solução para competências conflitantes, ver Vogel/Norouzi, The European Arrest Warrant, ne bis in idem and the problem of multiple jurisdictions, in: Guidicelle-Delage/Manacorda (Coord.), L’intégration pénale indirecte, Paris, 2005, p. 155 177 (171-175).

25 Cf. observações gerais na nt. 20. Especialmente sobre o modelo suíço, ver Pieth, in: Instituto Nacional de Ciencias Penales (Coord.) (nt. 20), p. 423-435. Sobre a cooperação com o Tribunal Internacional de Justiça segundo o Tratado de Roma, cf. a lei correspondente de 21.06.2002, BGBl. I, 2002, p. 2144, assim como Meißner, Die Zusammenarbeit mit dem Internationalen Gerichtshof nach dem Römischen Statut, 2003; Wilkitzki, International Criminal Law Review 2 (2002), p. 195-212.

26 Cf. observação na nt. 25. Especialmente sobre as Nações Unidas, cf. Witschel/Brandes, Die Vereinten Nationen und die Bekämpfung des internationalen Terrorismus, Zeitschrift für Politik, Sonderband 1, 2006, p. 22-50; sobre o Mercosul, ver: Vervaele, International Comparative Law Quarterly 2005, p. $389-409$ (p. 401 e ss.).

27 Cf. Capus, Revue de science criminelle et de droit pénal comparé, 2005, p. 251-263; FISCHERLESCANO/TEUBNER, Regime-Kollisionen: Zur Fragmentierung des globalen Rechts, 2006; Luhmann, Die Weltgesellschaft, in: idem, Soziologische Aufklärung 2, 2. ed., 1982, p. 51-71 (63); Teubner, in: Brand/Stempel (Coord.), Soziologie des Rechts, Festschrift für Erhard Blankenburg zum 60. Geburtstag, 1998, p. 233-244; Vogel, GA 2002, p. 517-534 (520). Um tratamento jurídico-teórico detalhado sobre a problemática é proposto por: Ost/Van de Kerchove, De la pyramide au réseau? Pour une théorie dialectique du droit, Brüssel, 2002. Sobre os sistemas de controle de agentes particulares, cf. infra II.B.2.b na nt. 147. Sobre a harmonização e internacionalização do direito penal, decorrente dos processos de influências cf. Sieber (nt. 2), in: Sieber/Albrecht (Coord.), p. 80 e ss. (90 e ss.).

28 Cf. detalhadamente, infra c).

29 Sobre a questão da legitimação democrática do direito penal europeu cf. Sieber, ZStW 103 (1991), p. 957-979 (969 e ss.); idem, in: Duttge et al. (Coord.), Gedächtnisschrift für Ellen Schlüchter, 2002, p. 107-116 (114), assim como Lüderssen, GA 2003, p. 71-84; Schünemann, StV 2005, p. 681-685; Vogel, ZStW 116 (2004), p. $400-423$ (416 e s.), e também a exposição sintética da discussão na Dresdner Strafrechtslehrertagung em Kreß, ZStW 116 (2004), p. 445-474 (450 e ss.). Ver também, sobre esse assunto em geral, principalmente, Von Bogdandy, Gubernative Rechtssetzung, 2000; idem, ZaöRV 63 (2003), p. 853-877; ferner Bleckmann, JZ 2001, p. 54-58; Doehring, DVB1. 1997, p. 1133-1137; Stein, ZaöRV 64 (2004), p. 563-570; Stiglitz (nt. 8), p. 335-362.

30 Sobre conflitos de normas na determinação da ordre public no contexto da cooperação jurídica clássica cf. Vogel, in: Grützner/Pötz (Coord.), Internationaler Rechtshilfeverkehr in Strafsachen, Loseblattsammlung, 64. Aktualisierung, 2. ed., 2004 , v. $1, \S 73$, Rn. 26 e ss. Sobre a colisão e a contradição de normas de ordenamentos jurídicos diversos, ver, a respeito do relacionamento de direito comunitário e direito nacional BVerfGE 73, p. 339 e 387 - Solange II; sobre o relacionamento do direito comunitário com a Convenção Européia dos Direitos do Homem, EGMR, NJW 2006, p. 197-204Bosphorus /Irland; sobre o relacionamento do direito comunitário europeu e da Convenção Européia dos Direitos do Homem com o direito da ONU, EuGH Case T49/04, Hassan v. Council of the European Union, de 12.07.2006. Ver também Göran, Nordic Journal of International Law 72 (2003), p. 291304 (p. 293 e ss.); Bernhardt, in: Simma (Coord.), The Charter of 
the United Nations, 2. ed. Oxford, 2002, v. 2, Art. 103 Rn. 3, 9, 16. Um exemplo atual para esses problemas são as novas smart sanctions do Conselho de Segurança da ONU; cf. Biehler, Archiv des Völkerrechts 41 (2003), p. 169-181; Schmalenbach, JZ 2006, p. 349-353.

31 Cf. Sieber, JZ 1997, p. 367-381 (374 s.); idem, in: Duttge et al. (Coord.) (nt. 29), p. 111 e s.; idem, in: Instituto Nacional de Ciencias Penales (nt. 20), p. 5-26; crítico, Klip, NStZ 2000, p. 626-630. Sobre as técnicas de harmonização cf. Sieber (nt. 2), in: Sieber/Albrecht (Coord.), p. 87 e ss.; Tiedemann, ZStW 116 (2004), p. 945 -958 (949 e ss.); sobre o estado de harmonização do direito penal material até o ano de 2004 na terceira coluna, cf. Hecker, Europäisches Strafrecht, 2005, p. 365-420; para uma análise detalhada, com base no exemplo da punibilidade no contexto do exercício profissional, cf. Dannecker, ZStW 117 (2005), p. 697-748 (714 e ss.).

32 Cf. Sieber (nt. 2), in: Sieber/Albrecht (Coord.), p. 86.

33 Cf. historicamente, sobre a função de garantia cultural do princípio penal de territorialidade: Kohler, Internationales Strafrecht, 1917, p. 92 s., assim como, em geral sobre as especificidades culturais no direito penal, Mayer, Rechtsnormen und Kulturnormen, Breslau, 1903. Sobre a cultura jurídica européia como variedade e unidade, cf. Häberle, Europäische Rechtskultur, 1994, p. 26-29; sobre o enraizamento cultural do direito penal e sua observância no contexto da integração dos sistemas penais europeus, cf. Greve, European Criminal Policy: Towards Universal Laws?, in: Jareborg (Coord.), Towards Universal Law, Trends in national, European and international lawmaking, Uppsala, 1995, p. 91 116 (112); Sieber, JZ, 1997, p. 367-381 (375); idem, in: Duttge et al. (Coord.) (nt. 29), p. 110 e s., criticamente, em especial, Weigend, ZStW 105 (1993), p. 774-802 (790 e ss.), assim como Eser, Poinikos Logos 5/2002, p. 2157-2170 (2162 e ss.)

34 Cf. Sieber, JZ 1997, p. 367-381, assim como idem, in: Duttge et al. (Coord.) (nt. 29), p. 107-116.

35 Cf. nt. 21 supra sobre mandado de detenção europeu, a Decisão-Quadro do Conselho sobre o Mandado de Detenção Europeu e o Processo de Entrega de Presos entre Estados-Membros 2002/584/JI de 13.06.2002, Abl. L 190, especialmente a revogação da lei do mandado de detenção europeu alemã de 21.07.2004 (BGBl. I, 2004, 1748) pelo Tribunal Constitucional Federal, BVerfG, NJW 2005, p. 2289-2303, e, sobre isso, Schünemann, StV 2005, p. 681-685 m.w.N., assim como a nova lei para a internalização da Decisão-Quadro do Conselho sobre o Mandado de Detenção Europeu e o Processo de Entrega de Presos entre Estados-Membros de 20.07.2006, BGBl. I, 2006, 1721, e Von Bubnoff, Der Europäische Haftbefehl, 2005/2006.

36 Cf. art. 13 letra $e$ da sugestão para o projeto de Decisão-Quadro do Conselho sobre o Mandado Europeu de Obtenção de coisas, escritos e dados para uso em processo penal, KOM (2003), p. 688.

37 Cf. art. 4, Nr. 7, letra a, da Decisão-Quadro do Conselho sobre o Mandado de Detenção Europeu e o Processo de Entrega de Presos entre Estados-Membros 2002/584/JI de 13.06.2002, Abl. L 190.

38 Quando o reconhecimento de decisões nacionais é empregado como instrumento do direito penal transfronteiriço, esse instrumento precisa respeitar as especificidades de cada ordenamento jurídico em questão, como mostra o exemplo das exceções territoriais e materiais no reconhecimento mútuo de decisões no contexto do mandando de detenção europeu e do planejado mandado europeu de obtenção de provas. Nesse modelo, no entanto, a aplicação extraterritorial de decisões nacionais por meio de reconhecimento mútuo constitui a regra, e a sua negação, a exceção.

39 Cf. supra nt. 27 e infra 2.2.2.a.dd.

40 Cf. sobre o objetivo da elaboração de uma teoria, supra nt. 2.

41 Sobre o conceito cf. Hassemer, NStZ, 1989, p. 553-559; idem, in: Schünemann et al. (Coord.), Festschrift für Claus Roxin zum 70. Geburtstag, 2001, p. 1001-1019; Roxin, in: Dolcini/Paliero, Studi in onore di Giorgo Marinucci, 2006, p. $715-737$ (728 e ss.).

42 Cf. sobre tais funções do direito penal, observação supra na nt. 7.

43 Sobre o cruzamento do crime organizado com a infra-estrutura das organizações terroristas cf. Diwell, in: Griesbaum et al. (Coord.), Strafrecht und Justizgewährung, Festschrift für Kay Nehm zum 65. Geburtstag, 2006, p. 101-109 (107). 
44 Cf., fundamentalmente, Lau, Soziale Welt, 1989, p. 418-436 (423 e ss.); além de Bonß, Vom Risiko Unsicherheit und Ungewißheit in der Moderne, 1995, p. 80.

45 Cf., sobre o contexto geral, os artigos em: Mansell/Collins (Coord.), Trust and crime in information societies, Cheltenham/Northampton-MA 2005.

46 Dificuldades técnicas de esclarecimento manifestam-se na internet, em especial, na busca de agentes criminosos e na avaliação de dados gravados digitalmente (e freqüentemente codificados), que somente podem ser analisados com conhecimento técnico específico ou nem podem ser abertos. O grande número de dados salvados e transmitidos leva a outras dificuldades para os investigadores. Em virtude da especialização econômica, também há problemas desse gênero na avaliação dos dados, em um contexto econômico ou técnico complexo, na área dos crimes econômicos. Os problemas de perseguição existentes são agravados, em muitos campos, pelos crimes cometidos em massa (proliferação de vírus de computadores, cópias piratas ou conteúdo de pronografia infantil na internet e outros). Cf. sobre os problemas práticos da investigação penal na internet: Sieber, in: Waltermann/Machill (Coord.), Protecting our children on the internet - towards a new culture of responsibility, 2000, p. 319-399 (345-378).

47 Cf. Delmas-Marty, in: Collège de France (Coord.) (nt. 18), p. 695-720 (710 e ss.).

48 Cf. os artigos em O’Day (Coord.), Weapons of mass destruction and terrorism, Aldershot et al. 2004.

49 Cf. Guillemin, Biological Weapons - From the Invention of State Sponsored Programs to Contemporary Bioterrorism, 2006; National Research Council, Globalization, Biosecurity, and the Future of the Life Sciences, 2006.

50 Cf., embora de difícil comprovação, o relatório de Nasiri, Mein Leben bei Al Qaida, 2006, p. 179-182, 202-207, 230-236.

51 Cf. Sieber, CR 1995, p. 100-113 (111 e s.).

52 Cf. sobre o último, infra nt. 153.

53 Cf. detalhadamente, infra nt. 75.

54 Cf. observação supra, nt. 13.

55 Cf. sobre isso, por último, Stiglitz (nt. 8), p. 236 e ss., com a observação de que o faturamento do produtor de automóveis americano General Motors, de 191,4 bilhões de dólares, em 2004, foi maior do que o Produto Interno Bruto de 148 países, e que o faturamento da rede de verejo americana Wal-Mart, com 282,5 bilhões de dólares, foi maior do que o PIB de todos os países africanos ao sul do Saara juntos. Ver também, sobre esse assunto, os artigos em Tiedemann (Coord.), Multinationale Unternehmen und Strafrecht, 1980.

56 Cf., resumidamente sobre crimes econômicos, Bundesministerium des Innern/Bundesministerium der Justiz (Coord.), Zweiter Periodischer Sicherheitsbericht, 2006, p. 218-280; Müller-Gugenberger (Coord.), Wirtschaftsstrafrecht. Handbuch des Wirtschaftsstraf- und -ordnungswidrigkeitenrechts, 4. ed., 2006; Tiedemann, Wirtschaftsstrafrecht. Besonderer Teil, 2006. Speziell zur Korruption siehe Transparancy International, Jahrbuch Korruption 2006, 2006.

57 Cf. estudos da Financial Action Task Force (nt. 10). Sobre o mercado financeiro mundial e seus efeitos, cf. Soros, Die Krise des globalen Kapitalismus, 1998. Sobre o papel do controle particular, ver relatório de Wood, Governing Global Banking, The Basel Committee and the Politics of Financial Globalisation, Aldershot 2005.

58 Cf. Schaller, Private Sicherheits- und Militärfirmen in bewaffneten Konflikten, (Coord. pela Stiftung Wissenschaft und Politik - Deutsches Institut für Internationale Politik und Sicherheit, 2005), assim como - por exemplo - o sítio da maior empresa militar <http://www.blackwaterusa.com>, acesso em: 18 dez. 2006].

59 Cf., por exemplo, Heine, in: Pieth/Seelmann (Coord.), Prozessuales Denken als Innovationsanreiz für das materielle Strafrecht, Basel 2006, p. 31-42 (32 e ss.).

60 Cf. infra II.B.2.a.cc, 2.2.2.b. 
61 Cf. a pesquisa empírica de Sieber/Bögel (nt. 16), p. 33 e ss., 37 e ss., 56 e ss.; Sieber, JZ, 1995, p. $758-768$.

62 Cf. sobre o terrorismo as pesquisas de Mayntz, Berliner Journal für Soziologie 14 (2004), p. 251-262, e de Jackson, Studies in Conflict \& Terrorism 29 (2006), p. 241-262. Sobre a utilização da internet, cf. O’Day, Cyberterrorism, Aldershot et al. 2004.

63 Cf. sobre o moviemento zapatista mexicano, os estudos de Garrido/Halavais, in: McCaughey/Ayers (Coord.), Cyberactivism: online activism in theory and practice, London, 2003, p. 165-184.

64 Cf. Weimann, Terror on the Internet: The New Arena, the New Challenges, Washington 2006, e Bronkhorst/Eissens (Coord.), Hate on the Net, Virtual nursery for In Real Life crime, disponível em: <http://www.jugendschutz.net/pdf/osce_paris.pdf>, acesso em: 18 dez. 2006.

65 Cf., resumidamente, Münkler, Die neuen Kriege, 2. ed., 2005, p. 175-205; idem, Der Wandel des Krieges, Von der Symmetrie zur Assymmetrie, 2. ed., 2006, p. 221-247. Especialmente sobre a situação na Alemanha, ver Bundesministerium des Innern/Bundesministerium der Justiz (Coord.) (nt. 56), p. 174-190.

66 Cf. observação supra, na nt. 43.

67 Cf. também Münkler, in: Bundeskriminalamt (Coord.), Neue Allianzen gegen Kriminalität und Gewalt, 2006, p. 17-31 (24 e ss.).

68 Sobre a criação de failed states, cf. Münkler (nt. 67), in: Bundeskriminalamt (Coord.), p. 17-31 (19 e ss.). Sobre o tratamento normativo de "países falidos", cf. Geiß, "Failed States", Die normative Erfassung gescheiterter Staaten, 2005. Para um panorama sobre os fundamentos fáticos dos crimes contra a ordem econômica nos "países falidos" e suas conseqüências internacionais: Gros, British Journal of Criminology 43 (2003), p. 63-80.

69 Tal mudança, de uma guerra entre Estados para novas formas assimétricas de guerra, pode ser vista, em parte, como indício para uma perda da importância de um mundo de Estados e a ascensão de novos agentes políticos. Cf. Münkler (nt. 67), in: Bundeskriminalamt (Coord.), p. 28 e ss.

70 Cf. também infra nt. 166.

71 Cf. detalhadamente, infra 2.2.2.a.ee e ss., 2.2.3.b.

72 Cf. Geiß (nt. 68), p. 292-307.

73 Cf. BGHSt 46, p. 212 e ss. Atual, sobre o direito de aplicação de penas, ver Cornils, JZ 1999, p. 394-398; Sieber, NJW 1999, p. 2065-2073.

74 Cf. Koch, in: Arnold et al. (Coord.), Menschengerechtes Strafrecht, Festschrift für Albin Eser zum 70. Geburtstag, 2005, p. 1091-1118 (1111).

75 Cf., por exemplo, os resultados da pesquisa de Wetzels/Brettfeld, Auge um Auge, Zahn um Zahn? Migration, Religion und Gewalt junger Menschen, 2003, p. 186-188, assim como a pesquisa sobre a avaliação de gravidade dos delitos de Braun, Migration und interkultureller Konsens, Ein interkultureller Ausblick, 2002, p. 154-163. Sobre a valoração da vingança de sangue por meio da jurisprudência cf. Nehm, in: Arnold et al. (Coord.), Menschengerechtes Strafrecht, Festschrift für Albin Eser zum 70. Geburtstag, 2005, p. 419-429; sobre o esclarecimento do alto potential de violência de grupos de criminosos albaneses: Arsovska, European Journal of Crime, Criminal Law and Criminal Justice 14/2 (2006), p. 161-184. Além disso, é também de grande importância o crescente potencial de conflito com a retirada do Estado do bem-estar social, de subculturas no contexto municipal, como mostram as perturbações nas zones urbaines sensibles de Paris; cf. sobre a correspondente violência de Maillard/Roché, European Journal of Criminology 2004, p. 111 -151 (131 e ss.), assim como sobre a violência entre jovens Dubet, in: von Trotha (Coord.), Soziologie der Gewalt, 1997, p. 220-234, e Body-Gendrot, European Journal of Crime, Criminal Law and Criminal Justice 2005, p. 4-26.

76 Cf. sobre os problemas resultantes para a ciência do direito, social e econômica Mayntz, Einleitung und Zusammenfassung, in: Mayntz/von Bogdandy/Genschel/Lütz (nt. 8), p. 9-18 (13 e ss.), e outros artigos no volume. 
77 Cf. Beck (nt. 3), p. 45 e ss.; Beck/Lau, The British Journal of Sociology 56 (2005), p. $525-557$ (532 e s.); Münkler (nt. 67), in: Bundeskriminalamt (Coord.), p. 18 e ss. Sobre o "estado transnacional” ver Grande, Globalisierung und die Zukunft des Nationalstaats, in: Beck/Bonß (Coord.), Die Modernisierung der Moderne, 2. ed., 2001, p. 261-275 (274). Sobre o papel das organizações e acordos internacionais, cf. Tomuschat, Recueil des cours de l'Académie internationale de la Haye 281 (1999), p. 40 e ss.

78 Cf. Jung, GA 1996, p. 507-517 (515).

79 Cf., sobre o direito inimigo, observação infra nt. 98.

80 Cf., fundamentalmente, Jakobs, ZStW 97 (1985), p. 751-785; também Beck, Unrechtsbegründung und Vorfeldkriminalisierung, 1992, assim como a jurisprudência do BGHSt 47, 214, por Rath, GA 2003, 823-840. Cf. também as notas sobre a crítica da escola de Frankfurt nos anos 90 em Schünemann, GA 1995, p. $201-229$ (210 e s.).

81 Sobre os delitos de organização cf. no tocante ao conceito de associação criminal BGH, NJW 2005, p. 80-83, assim como no tocante à ampliação abrangente dos delitos no momento anterior à sua execução Dahs, H., NJW, 1976, p. 2145-2151 (2147 s.); Jakobs, HRRS, 2006, p. 289-297 (295); Roxin (nt. 41), in: Dolcini/Paliero (Coord.), p. 734; F. - C. Schroeder, Die Straftaten gegen das Strafrecht, 1985, p. 17 e 28-29; sobre a europeização do conceito de unificação, Kreß, JA 2005, p. 220-228; Von Heintschel-Heinegg, in: Hoyer et al. (Coord.), Festschrift für F.-C. Schroeder, 2006, p. 799 808. Sobre os tipos penais de conspiração nos EUA, ver Katyal, Yale Law Journal, 112 (2003), p. 1307-1398; Siesseger, William and Mary Law Review, 46 (2004), p. 1177-1218. Sobre especiais figuras de imputação em direito internacional penal cf. Danner/Martinez, California Law Review, 93 (2005), p. 75-169 (102 e ss.). Sobre um movimento contrário de liberalização na responsabilidade do provedor na internet, ver Sieber, Kinderpornographie, Jugendschutz und Providerverantwortlichkeit im Internet, Eine strafrechtsvergleichende Untersuchung, 1999, p. 32-46 e 61-65, assim como, em direito comparado, idem, Responsibility of Internet-Providers, in: Lederman/Shapira (Coord.), Law, Information and Information Technology, The Hague et al., 2001, p. 231-292.

82 Cf., fundamentalmente, Jakobs, ZStW 97 (1985), p. 751-785. Sobre bens jurídicos supra-individuais e crimes de perigo, ver Greve, European Journal of Crime, Criminal Law and Criminal Justice, 2005, p. 515-532; Hassemer, StV 2006, p. 321-332 (326 e s.); Hefendehl, Kollektive Rechtsgüter im Strafrecht, 2002; Tiedemann, Tatbestandsfunktionen im Nebenstrafrecht, 1969, p. 111-134; Wohlers, Deliktstypen des Präventionsstrafrechts. Zur Dogmatik "moderner" Gefährdungsdelikte, 2000; Zieschang, Die Gefährdungsdelikte, 1998, p. 214-220, 245-251 e 388-393. Sobre crimes de posse, ver Struensee, in: Samson (Coord.), Festschrift für Gerald Grünwald zum siebzigsten Geburtstag, 1999, p. 713-729.

83 Trata-se de formulações preliminares, que em 2007 poderiam gerar os primeiros projetos de leis.

84 Ver infra 2.2.3.b, assim como sobre as possibilidades legislativas no tocante à "problemática de potenciais suicidas" do ponto de vista norte-americano, Chesney, Harvard Journal of Legislation 42 (2005), p. 1-89. Ver também 18 USC $\S 2339-2339 D$.

85 Cf. também Hassemer (nt. 82), StV 2006, 323.

86 Sobre a aplicação de preventiva investigação cruzada cf. BVerfG, NJW 2006, 1939-1951; Lisken, $N V_{W} Z$ 2002, p. 513-519. Sobre "atuação como serviço de inteligência", cf. Paeffgen, StV 2002, 336-341; idem, GA 2003, 647-671.

87 Sobre a uniformização dos métodos sigilosos de investigação no processo penal, daqui em diante o "Referentenentwurf für ein Gesetz zur Neuregelung der Telekommunikationsüberwachung und anderer verdeckter Ermittlungsmaßnahmen sowie zur Umsetzung der Richtlinie 2006724/CE” de 27.11.2006 (hekt.). Sobre a prática e a eficiência da escuta telefônica na Alemanha, ver Albrecht/Dorsch/Krüpe, Rechtswirklichkeit und Effizienz der Überwachung der Telekommunikation nach den $\S \S 100 \mathrm{a}, 100 \mathrm{~b}$ StPO und anderer verdeckter Ermittlungsmaßnahmen, 2003. Sobre os limites jurídicos no campo da investigação cruzada, cf. BVerfGE, NJW 2006, p. 1939-1951.

88 Cf. também Albrecht (nt. 6), JURA (Ungarn) 2005/2, p. 11 e s.; Klett-Straub, German Law Journal 7 (2006), p. $967-975$.

89 Cf. Weßlau, Vorfeldermittlungen: Probleme der Legalisierung "vorbeugender Verbrechensbekämpfung" aus strafprozeßrechtlicher Sicht, 1989; Wolter, GA 1999, p. 158181; Kühne, Strafprozessrecht, 6. ed., 2003, Rn. 393. 
90 Cf. detalhadamente, infra nt. 161.

91 Ver infra II.B.3.b., especialmente. nt. 159 e 164. Cf., entretanto, sobre o Anti-terrorism, Crime and Security Act 2001 (ATCSA), na Grã-Bretanha também a sentença do Appellate Committee do House of Lords no caso A and others v. Secretary of State for the Home Department; X and another v. Secretary of State for the Home Department, de 16.12.2004, All England Law Reports 2005 (3), p. 169-263.

92 Cf. por exemplo, na França, o tipo penal genérico, criado em 2006, de "falta de justificativa de rendimentos correspondentes ao nível de vida" no art. 321-6 Code Pénal (assim como o correspondente tipo penal especial para o terrorismo no art. 421-2-3).

93 Cf. sobre a nulidade da autorização para abatimento na lei de segurança da aviação (Luftsicherheitsgesetz), BVerfG, NJW 2006, p. 751-761; sobre o debate relativo à tortura, por último, Roxin, in: Arnold et al. (Coord.), Menschengerechtes Strafrecht, Festschrift für Albin Eser zum 70, Geburtstag, 2005, p. 461-471 (468 e s.), assim como Reemtsma, Folter im Rechtsstaat?, 2005; Saliger, ZStW 116 (2004), p. 35-65.

94 Cf. genericamente, sobre acordos no âmbito processual, BGH, NJW 2005, 1440-1447, assim como a sugestão da Câmara Federal de Advogados (Bundesrechtsanwaltskammer) sobre a regulamentação legal de acordos de sentença no processo penal, ZRP 2005, p. 235-241, e Schünemann, in: Lorenz et al. (Coord.), Festschrift für Andreas Heldrich, 2005, p. $1177-1195$.

95 Cf. Meyer, HRRS, disponível em: <http://www.hrr-strafrecht.de>, acesso em: 18 dez. 2006, p. 178-185; Takei, Boston College Law Review 47 (2006), p. 581-626. Ver também infra 2.2.2.a.ff.

96 Sobre competências especiais de tribunais, por exemplo, para delitos penais com "grande complexibilidade" ou "complexibilidade muito grande" ("grande complexité" ou "très grande complexité") cf. in Frankreich art. 704 inc. 3 e 706-75 Code de Procédure Pénale.

97 Respectivas medidas interventivas especiais para determinados delitos são tradicionais, principalmente na França, por exemplo, para crimes de terrorismo, contra a ordem econômica, a corrupção em nível europeu, crimes marítimos, para proteção do Estado e militar, assim como para crimes contra a saúde pública. Os arts. 706-73 e ss. CPP, introduzidos pela Lei 2004-204, de 09.03.2004, permitem ainda, para os delitos da criminalidade organizada, previstos em um detalhado catálogo de tipos penais, uma detenção policial prolongada, uma mais ampla escuta telefônica, buscas noturnas, investigações encobertas e vigilância acústica e visual de ambientes. Sobre os últimos desenvolvimentos do combate contra o terrorismo na França, cf. a Lei 2006-64, de 23.01.2006.

98 Cf., por último, Jakobs, HRRS 2006, p. 289-297 (295), idem, ZStW 117 (2005), p. 839-851, idem, HRRS 2004, p. 88-95 (93), e idem, ZStW 97 (1985), p. 751-785. Cf. também Arnold, HRRS 2006, p. 303-315; Bung, HRRS 2006, p. 63-71; Hörnle, GA 2006, p. 80-95, e, no contexto espanhol, Zaffaroni, El enemigo en el derecho penal, Bogotá, 2006.

99 Cf. Bär, Der Zugriff auf Computerdaten im Strafverfahren, 1992, p. 367 e ss., 387 e ss.; Kugelmann, TMR 2002, p. 14-23 (18 e s.).

100 Cf. $\S \S 2,3,6,9,11$ GWG e art. 6 e ss. da Diretiva 2005/60/CE de 26.10.2005, Abl. L 309/15, sobre a prevenção da utilização do sistema financeiro para fins de lavagem de dinheiro e de financiamento do terrorismo e outras observações na nt. 104.

101 Cf. $\S \S 9,10,33$ inc. 1 Nr. 3, da Lei de negociação de títulos e valores mobiliários (Wertpapierhandelsgesetz) e art. 6, inc. 6 e 19, da Diretiva 2003/6/CE, de 28.01.2003, ABl. L 96 sobre negócios de insider e manipulações de mercado.

102 Sobre a conservação de dados, cf. a Diretiva 2006/24/CE, de 15.03.2006, Abl. L 105/54, sobre a conservação de dados gerados ou analisados no contexto da disponibilização pública de serviços de comunicação eletrônica ou de redes públicas de comunicação, assim como a pesquisa de Breyer, Die systematische Aufzeichnung und Vorhaltung von Telekommunikations-Verkehrsdaten für staatliche Zwecke in Deutschland, 2005. Sobre as obrigações de colaboração de particulares para fins da investigação penal, cf. Hamm, NJW 2001, p. 3100-3101, assim como o art. 19 , parágrafo 4, da Convention on Cybercrime, ETS Nr. 185, de 08.11.2001 (ver também Explanatory Report, parágrafos 200-202). 
103 Cf. também Ziercke, in: Bundeskriminalamt (Coord.), Neue Allianzen gegen Kriminalität und Gewalt, 2006, p. 33-48 (42 e ss.).

104 Cf. Diretiva 2001/97/CE de 04.12.2001, Abl. L 344/76 sobre a modificação da Diretiva 91/308/EWG do Conselho para a prevenção do uso do sistema financeiro para fins de lavagem de dinheiro. Relativamente à Alemanha, ver a Lei para melhoria do combate à lavagem de dinheiro e ao financiamento do terrorismo ("Gesetz zur Verbesserung der Bekämpfung der Finanzierung des Terrorismus"), de 08.08.2002, BGBl. I, 2002, p. 3105, assim como Herzog/Müllhausen, Geldwäschebekämpfung und Gewinnabschöpfung, 2006, e Wegner, NJW 2002, p. 794-796.

105 Cf. sobre a nova "arquitetura de segurança" e novos arquivos antiterror, Nehm, NJW 2004, p. 3285-3295; Schily (nt. 22), in: Bundeskriminalamt (Coord.), p. 12 e s., assim como nt. 43. Cf. também o Gemeinsame DateienGesetz, Bundestags-Drucksache 16/2950, aprovado em 1. ‥12.2006 pelo Parlamento Federal lemão (Bundestag).

106 Cf. Albrecht (nt. 6), JURA (Ungarn) 2005/2, p. 17; Diwell (nt. 43), in: Griesbaum et al. (Coord.), p. 101 109 (especialmente 103 e ss., 109); Nadelmann, Cops Across Borders, The internationalization of U.S. criminal law enforcement, Cambridge-MA, 1993, especialmente p. 103-188.

107 Cf. Sieber (nt. 2), in: Sieber/Albrecht (Coord.), p. 88 e 90, assim como os artigos em Biolley/Weyembergh (Coord.), Comment évaluer le droit pénal européen, Brüssel, 2006.

108 Cf. nt. 27.

109 Cf. sobre a detenção de suspeitos de terrorismo e sua transferência para outros países o relatório do relator especial do Conselho da Europa Marty, Alleged secret detentions and unlawful inter-state transfers involving Council of Europe member states, Draft report - Part II (Explanatory memorandum), AS/Jur (2006) 16 Part II (07.06.2006), e idem, Alleged secret detentions in Council of Europe member states, Information Memorandum II, AS/Jur (2006) 03 rev. (22.1.2006); sobre o congelamento de patrimônio por meio de regulamentos de direito administrativo e sua legalidade em nível europeu (e também incidentalmente internacional), as decisões do Tribunal de Primeira Instância das Comunidades Européias (EuG) de 21.09.2005 no caso T-306/01, OJ C 281/17, e de 12.12.2006 no caso T-228/02; sobre escuta de telecomunicações por meio do sistema de escuta Echelon, o Relatório do Parlamento Europeu de 11.7.2001, A5-0264/2001 PAR1; sobre a avaliação de bancos de dados da Swift, Süddeutsche Zeitung Nr. 143 de 24/25.6.2006, p. 1 e s.

110 Cf. supra 2.2.2.a.dd., assim como, sobre o fortalecimento das competências do serviço secreto no combate ao terrorismo na Alemanha, o Entwurf eines Gesetzes zur Ergänzung des Terrorismusbekämpfungsgesetzes, BundestagsDrucksache 16/2921, e sobre o direito de polícia, infra 2.2.3.b.

111 Cf. Eckert, The Politics of Security, Max-Planck Institute for Social Anthropology Halle, Working Papers 76, 2005. Sobre a ampliação desse sistema aos cidadãos naturalizados, cuja cidadania é revogada antes das decisões correspondentes, cf. nos EUA, Hooker, Emory Int1. Law Rev. 19 (2005), p. 305-381. Para o Canadá, cf. o processo security certificate, segundo Part I Division 9 do Immigration and Refugee Protection Act, que permite a detenção de estrangeiros em um especial processo de extradição. O exame judicial da prisão e conseqüente extradição pode ocorrer sem a presença do envolvido e de seu defensor jurídico, tendo como base informações de caráter sigiloso.

112 Cf. também - com base no exemplo da atuação norte-americana e israelense contra o terrorismo - infra 2.2.2.a.ff.

113 Cf. sobre o procedimento do direito de guerra contra o terrorismo nos EUA e em Israel, infra 2.2.2.a.ff. Sobre os critérios correspondentes na Alemanha, ver infra nt. 166.

114 Cf. as notícias no Süddeutschen Zeitung, n. 1, de 02.01.2007, p.1, n. 2, de 30.01.2007, p. 5, e n. 3, de 04.01.2007, p. 5, sobre uma conversa com o Ministro dos Assuntos Internos, Schäuble. Sobre os mais novos planos para um possível apoio da polícia por intermédio das forças armadas com meios militares na defesa de um ataque terrorista, ver também Süddeutsche Zeitung, n. 264, de 16.11.2006, p. 6, assim como sobre as novas alianças entre polícia e exército, Ziercke (nt. 103), in: Bundeskriminalamt (Coord.), p. 44 e s.; além disso, Kästner, idem, p. 71-72. No entanto, até agora a ação militar contra o terrorismo é predominantemente rejeitada na Alemanha, cf. Schily (nt. 22), in: Bundeskriminalamt (Coord.), p. 13 e s. A citada decisão do Tribunal Constitucional Federal sobre a lei de segurança da 
aviação não dizia respeito, portanto, ao envolvimento das forças armadas para defesa ou ataque, e sim à cooperação administrativa com a polícia para a mobilização em caso de catástrofes, cf. BVerfG NJW 2006, p. $751-761$ (754 e ss.).

115 Cf. Beck (nt. 3), p. 10 s.; Münkler (nt. 67), in: Bundeskriminalamt (Coord.), p. 17; da perspectiva criminológia, Albrecht, Schweizerische Zeitschrift für Kriminologie, 2002, p. $5-17$ (8 e ss.). Sobre a situação jurídica nos EUA cf. Vervaele, European Journal of Crime, Criminal Law and Criminal Justice 2005, p. 201-254, assim como Seamon/Gardner, Harvard Journal of Law and Public Policy 28 (2004-2005), p. 319-463; sobre a história da origem do Patriot Act e suas implicações para o direito das medidas de investigação estatais, assim como sobre a inclusão de particulares nas investigações, ver Howell, George Washington Law Review 72 (2003-2004), p. $1145-1207$ (1178-1207). Sobre a situação nos EUA e em Israel cf. Gross, The Struggle of Democracy Against Terrorism, Charlottesville 2006, especialmente p. 92-119.

116 Cf. também Hassemer (nt. 82), StV 2006, p. 322, 329 e ss.

117 Cf. nesse contexto, também no tocante à defesa contra perigos, Hoffmann-Riem, ZRP 2002, p. 497-501. Sobre a legitimação parlamentar no direito penal, cf. supra nt. 29.

118 Cf. Ackerman, Yale Law Journal 113 (2004), p. 1029-1091 (1032 e ss.); Meierhenrich, Journal of Conflict and Security Law 11 (2006), p. 1-40 (7 e ss.).

119 A morte objetivada de um terrorista é discutida em Israel sob pontos de vista jurídicos. Cf. Gross (nt. 115), p. 220 e ss., assim como, detalhadamente, a decisão da High Court of Justice israelense, HCJ 769/02, de 13.12.2006. O mais alto tribunal israelense entende, obviamente, que medidas de direito penal para o combate do terrorismo não são suficientes (cf. por exemplo Ziss. 21 e 26 da motivação da sentença). O presidente do tribunal Barak reconhece em sua motivação para os international armed conflicts além dos combatants e dos civilians, entretanto não reconhece uma terceira categoria dos unlawful combatants, como o governo americano o fez para o direito dos EUA em casos de terrorismo, em um outro contexto. Ele justifica as mortes, porém, como ação contra civis permitida em direito de guerra, civis estes que apoiem terroristas ativos (cf. Ziss. 30 e ss.; parcialmente uma outra opinião, vice-presidente Rivlin, que não vê a classificação dos terroristas mortos em grupos de unlawful combatants ou de uncivilized civilians como decisiva, cf. Ziss. 2 de sua motivação).

120 Cf. Bellinger, Fifth Anniversary of September 11 th Attacks, Remarks, Rome, September 11, 2006, disponível em: <http://www.state.gov/s/l/rls/73082 htm>, acesso em: $18 \mathrm{dez} .2006$.

121 Sobre os problemas dessa motivação, cf. Ackerman, Yale Law Journal 113 (2004), p. 1029-1091 (1032 e ss.).

122 Cf. Burnham, Introduction to the Law and Legal System of the United States, 3. ed., 2002, p. 665 e s.; Ramsey, University of Chicago Law Review 69 (2002), p. 1543-1638.

123 Cf. Wang, Harvard Journal on Legislation 43 (2006), p. 517-534; Koh, American Journal of International Law 96 (2002), p. 337-344. Essa última atuação foi declarada inconstitucional na decisão Hamdan da Supreme Court, cf. Hamdan $v$. Rumsfeld, 126 p. Ct. 2749 (2006). Por meio do Military Commission Act de 2006, tais tribunais estão sendo fundamentados em uma nova base legal, em reação ao caso "Hamdan". Ver Military Commissions Act of 2006, Pub. L. n. 109-366, 120 Stat. 2600 (2006), e The Manual for Military Commissions, 2007, disponível em: <http://www.defenselink. mil/news/commissonsmanual.html>, acesso em: 26 fev. 2007; Katyal, Harvard Law Review 120 (2006), p. 65-123.

124 Cf. Ratner, Litigating Guantanamo, in: Kaleck et al. (Coord.), International Prosecution of Human Rights Crimes, 2006, p. 201 e 208. Ver também Hamdi v. Rumsfeld 124 p. Ct. 2633 (2004).

125 Cf. Military Commissions Act of 2006, Sec. 948r, (c), (d).

126 Cf. Rasul v. Bush, 124 p. Ct. 2686 (2004).

127 O fato de que também o Legislativo aceitou tal procedimento no Military Commissions Act tem grandes conseqüências nos poderes de controle da Supreme Court em processos futuros. Segundo a constitutição norteamericana, o apoio explícito do presidente pelo congresso é um fator decisivo para a determinação dos limites de seus poderes, cf. Youngstown Sheet \& Tube Co. v. Sawyer, 72 p. Ct. 863 (1952), p. 870 e s. (Jackson, J., concurring). 
128 Cf. Ratner (Fn. 124), in: Kaleck et al. (Coord.), p. 201, 203 e ss., com referência a casos anteriores de fugitivos do Haiti.

129 Cf. Arnold, ZaöRV 66 (2006), p. 297-320 (310 e ss.); Oeter, Archiv desVölkerrechts 40 (2002), 422 e ss. (437 e ss.).

130 Cf. Hamdan v. Rumsfeld, 126 p. Ct. 2749 (2006).

131 Por esse motivo, deveria ser pesquisado se relacionamentos de troca semelhantes espelham-se também nos pacotes de medidas de outros países envolvidos, ou se o desenvolvimento norte-americano descrito é passível de reprodução fora do contexto constitucional dos EUA.

132 Cf. Marty (nt. 109), Draft Report - Part II, Rdnr. 22.

133 Cf. Rodley, The Prohibition of Torture: Absolute Means Absolute, in: Kaleck et al. (Coord.), International Prosecution of Human Rights Crimes, p. 185-200 (187 e s.). Sobre interrogatórios pelas forças armadas regulares, cf. Department of Defense Appropriations Act, 2006, Sec. 1001-1004. Ver também a documentação de uma pesquisa interna do FBI sobre os métodos de interrogatório em Guantánamo, disponível em: <http://foia.fbi.gov/guantanamo/detainees.pdf>, acesso em: 3 jan. 2007].

$134 \mathrm{Na}$ literatura, são apresentadas - apesar de nem sempre de modo claro e praticável - diferenciações entre prevenções primárias, secundárias, terciárias e técnicas, além dos instrumentos de prevenção, intervenção e atuação posterior. Cf., resumidamente, Kaiser, Kriminologie, 3. ed., 1996, p. 246-271.

135 Cf. sobre a necessidade de tais medidas, Sieber, The International Handbook on Computer Crime, Chichester, 1986, p. $117-145$.

136 Cf. infra 3.2.3.c.bb., e, especialmente, nt. 211.

137 Cf. Sieber/Bögel (nt. 16), p. 363 e s.

138 Cf. Bundesministerium des Innern/Bundesministerium der Justiz (Coord.) (nt. 56), p. 184190

139 Cf. Sieber, SchweizStR 1996, 357-395 (377 e ss.).

140 Cf. Sieber/Bögel (nt. 16), p. 292-327.

141 Cf., em geral, Roxin (in: Dolcini/Paliero (Coord.), p. 733, assim como, especialmente sobre situações posteriores a conflitos, Report of the Secretary-General: The rule of law and transitional justice in conflict and postconflict societies, UN Doc. S/2004/616, 3.8.2004, e Wolfrum, in: Dahm/Delbrück/Wolfrum, Völkerrecht, Bd. I/3, 2. ed., 2002, § 190, p. 1014 e ss.

142 Cf. sobre a auto-regulação na internet Sieber (nt. 46), in: Waltermann/Machill (Hrsg), p. 319-399 (378 e ss.); sobre as normas do Conselho Alemão de Imprensa, OLG Köln, Urteil de 11.07.2006, Az. 15 U 30/06, <http://www.miur.de/dok/333.html>, acesso em: 18 dez. 2006.

143 Cf. Sieber, The Quarterly Review of Corporation Law and Society (Tokyo) 4/2006, p. 73-146.

144 Cf. supra nt. 49.

145 Cf. Sieber (nt. 46), in: Waltermann/Machill (Coord.), p. 319-399 (379 e ss.).

146 Di Fabio, Der Verfassungsstaat in der Weltgesellschaft, 2001, p. 69.

147 Cf. supra nt. 27 e 29.

148 Cf. Sieber, in: Waltermann/Machill (Coord.), (nt. 46), p. $319-399$ (379 e ss.). Tendências a uma privatização do direito penal se mostram em alguns ordenamentos jurídicos, por exemplo, em empresas privadas de segurança (às 
quais são atribuídos poderes especiais), na privatização da execução penal (por exemplo, nos EUA), no comprometimento de particulares para medidas de vigilância públicas (por exemplo, na descoberta de lavagem de dinheiro, no controle de telecomunicações e no controle de matérias-primas para a fabricação de drogas), na substituição de sanções penais por civis (por exemplo, ações treble damage ou poder disciplinar interno das empresas). Ver supra 2.2.2.a.cc e 2.2.2b.

149 Cf. Soek, The Strict Liability Principle and the Human Rights of Athletes in Doping Cases, The Hague, 2006. Ver também Vierweg/Sielmann (Ed.), Legal Comparison and the Harmonisation of Doping Rules, Berlin, 2007, assim como Koch, in: Röhricht/Vieweg (Coord.), Doping-Forum, 2000, p. 53-61 (61).

150 Cf. o não-envolvimento do Estado em Jakobs, Norm, Person, Gesellschaft - Vorüberlegungen zu einer Rechtsphilosophie, 1997. Criticamente, Kargl, GA 1999, p. 52-66 (66).

151 Cf. sobre a reinvindicação do cidadão por um Estado forte na sociedade de risco, Sieber, CR 1985, 100113 (112 e s.).

152 Cf., para o contexto alemão, Bundesministerium des Innern/Bundesministerium der Justiz (Coord.) (nt. 56), p. $485-533$.

$153 \mathrm{Cf}$. sobre a reação aos chamados dread risks no contexto de ataques terroristas por meio de um irracional comportamento para prevenir riscos, do ponto de vista da teoria do comportamento, Gigerenzer, Risk Analysis 26 (2006), p. 347-351.

154 Cf. Cornils/Greve, Denmark on the Road to Organized Crime, in: Fijnaut/Paoli (Coord.), Organised Crime in Europe, Patterns and Control Policies in the European Union and Beyond, Dordrecht, 2004, p. 853-878; Elbert, ZStW 118 (2006), p. 953-967; Hassemer (nt. 82), StV 2006, 325. Elbert fala também de "sociedades da insegurança e de medo dos outros".

155 Cf. sobre questões do princípio da democracia em nível supranacional, supra nt. 29.

156 Cf. também BVerfG, NJW 2006, 1939-1951; Hassemer (nt. 82), StV 2006, p. 328 e ss.

157 Cf. supra 2.2.2.a.ee e ff.

158 Cf., especialmente, Lei 2003-239, de 18.03.2003, e art. 706-88 Code de Procédure Pénal.

159 Cf. sobre esses Control Orders to Prevention of Terrorism Act 2005, de 11.03.2005. Ver, em geral, sobre as medidas antiterrorismo no Reino Unido, The Terrorism Act 2000, de 20.07.2000, The Anti-Terrorism, Crime and Security Act 2001, de 14.12.2001, e The Terrorism Act 2006, de 30.03.2006, assim como House of Commons/Home Affairs Committee, Terrorism Detention Powers, Fourth Report of Session 2005-06, v. 1, London, 20 June 2006. Sobre o novo programa do governo do primeiro-ministro Blair (com o objetivo de uma ampliação do atual prazo de 28 dias para um prazo de 90 dias) cf. Süddeutsche Zeitung n. 264, de 16.11.2006, p. 7.

160 Cf., por exemplo, § 28 PolG-BW; art. 17, 20 BayPAG (Detenção pelo máximo de duas semanas). Cf. também o esboço do art. 24e da lei federal suíça para o controle da segurança interna ("Schweizer Bundesgesetz zur Wahrung der internen Sicherheit") (prazo de 24 horas).

161 Sobre as restrições do Estado de direito e de política criminal contra o § 112a StPO cf. Hassemer (nt. 82), StV 2006, p. 323 e ss.; Roxin, Strafverfahrensrecht, 25. ed., 1998, § 30 Rn. 13 e s. Em geral, sobre motivos de prisão “apócrifas", ver Spinellis, in: Hoyer et al., Festschrift für F.C. Schröeder, 2006, p. 861-875 (867 e ss.).

162 Cf. sobre a crítica a tais delitos de organização, supra nt. 81 .

163 Sobre a - discutível - capacidade de rendimento do conceito de bem jurídico, cf. Roxin, Strafrecht. Allgemeiner Teil - Grundlagen, 4. ed., 2006, § 2 Rn. 1-141 (especialmente Rn. 2 e ss.); Dubber, ZStW 117 (2005), p. 485-518 (especialmente p. 501 e ss.); Hassemer/Neumann (nt. 4), in: Kindhäuser/Neumann/Paeffgen (Coord.), Vor $\S 1$ Rn. 108-195; Wohlers, GA 2002, p. 16-20 (16 e s.). Sobre a também discutível legitimação do § 129a, ver supra nt. 81. 
164 Cf. B VerfGE 109, p. 133-190 (133 e ss.). Sobre a qualificação da prisão preventiva posterior como direito penal no sentido da competência legislativa da Constituição, cf. BVerfG, NJW 2004, p. 750-761. Sobre a jurisprudência do BGH sobre o novo $§ 66 \mathrm{~b}$ StGB (prisão preventiva posterior) ver as decisões em StV 1006, p. 63-71, assim como Ullenbruch, NJW 2006, p. 1377-1385.

165 Cf. também Hassemer (nt. 82), StV 2006, p. 322 e ss.

166 Cf. sobre defesa "externa" e estado de necessidade "interno" segundo o direito alemão, art. 87 a, especialmente parágrafo IV, e art. 115 a GG, assim como Dürig, in: Maunz/Dürig, Grundgesetz Kommentar, Loseblattsammlung, 47. Lfg. 2006, Art. 87 a, especialmente Rn 100, assim como Herzog, aaO, Art. 115 a, especialmente Rn. 21, 26. Sobre a interpretação do art. 51 do estatuto da ONU e questões do direito de guerra contra terroristas, cf. os artigos fundamentais em Walter/Vöneky/Röben/Schorkopf (Coord.), Terrorism as a Challenge for National and International Law: Security versus Liberty?, 2004, especialmente p. 789 e ss. Ver sobre o problema fenomenológico dos ataques assimétricos às estruturas de rede em Estados territoriais, supra nt. 110, assim como sobre a situação nos EUA e em Israel cf. supra 2.2.2.a.ff.

167 Cf. Sieber/Bögel (nt. 16), p. 292-327.

168 Cf. Albrecht, Rechtstatsachenforschung zum Strafverfahren, 2005; Kaiser, Kriminologie, 3. ed., 1996, p. 32-67.

169 Cf. Jescheck, Strafrecht und Kriminologie unter einem Dach, 1980; idem, Strafrecht und Kriminologie unter einem Dach, in: Albrecht/Kürzinger (Coord.), Kriminologie in Europa - europäische Kriminologie?, 1994, p. 7-11. Sobre o início do trabalho conjunto, cf. também Kaiser, ZStW 83 (1971), p. 881-910.

170 Cf. supra 1.2.3.a.

171 Cf., por último, Biolley/Weyembergh (Coord.), Comment évaluer le droit pénal européen, Brüssel, 2006.

172 Cf. Hassemer (nt. 82), StV 2006, p. 328 e ss.; idem (nt. 161), in: Hoyer et al. (Coord.), Festschrift für F.C. Schroeder, 2006, p. 62, assim como supra 2.2.3.b.

173 Cf. sobre conceito, métodos e objetivos da dogmática do direito penal, Alexy, Theorie der juristischen Argumentation, 2. ed., 1991, especialmente p. 307 e ss.; Hassemer, Strafrechtsdogmatik und Kriminalpolitik, 1974, p. 143194; Hoyer, Strafrechtsdogmatik nach Armin Kaufmann, 1977, especialmente p. 2 e ss.; Langer, GA 1990, p. 435-466; Jescheck/Weigend, Lehrbuch des Strafrechts, 5. ed., 1996, § 6 I, p. 42; Roxin, Strafrecht Allgemeiner Teil, v. 1: Grundlagen, 4. ed., § 7 Rn. 1 e ss.; Vogel, Juristische Methodik, 1998, p. 123 e s.

174 Cf., fundamentalmente, Vogel, GA 2002, p. 517-534 (522 e ss.) e idem, GA 1998, p. 127-150.

175 Cf. Sieber (nt. 2), in: Sieber/Albrecht (Coord.), p. 103-109.

176 Cf. sobre o objetivo de aumentar os conhecimentos gerais além do aspecto histórico, infra nt. 196 Dubber, in: Reimann/Zimmermann (Coord.), The Oxford Handbook of Comparative Law, Oxford, 2006, p. 1287-1325 (1305 e ss.); Fletscher, The Grammar of Criminal Law, Bd. 1, Oxford, 2007, assim como Hirsch, ZStW 116 (2004), p. $835-854$ (p. 840 e ss. E, especialmente, p. 849 nt. 32); Vogel, GA 1998, p. 127-150. Sobre a correspondência da dogmática do direito penal e da política criminal ao sistema de direito penal, cf. Hassemer (nt. 173), p. 155-176.

177 Cf. mais aprofundadamente, infra III.B.3.a., assim como, detalhadamente, Sieber (nt. 2), in: Sieber/Albrecht (Coord.), p. 114 e ss., 137 e s., 140 e s.

178 Cf. especialmente Hirsch, ZStW 116 (2004), p. 835-854 (especialmente p. 850 e ss.).

179 Cf., sobre as relações - fundamentalmente de dupla função - da dogmática do direito penal e da política criminal, Hassemer (nt. 173), especialmente. p. 143 e ss., 155, 176. Assim, pode aqui ser colocada a questão se a dogmática jurídica somente pode ser executada tendo como fundamento uma dogmática de direito penal realmente existente, ou se também pode proporcionar uma "teoria pura do direito penal generalizável, isto é, com conclusões igualmente válidas para todos os ordenamentos jurídicos possíveis”; nesse último sentido, Langer, GA 1990, p. 435-466 
(436). Cf. também sobre teoria do direito como "dogmática geral do direito", que ultrapassa um determinado ordenamento jurídico e, por isso, diferencia-se de dogmáticas especiais do direito em razão do grau de abstração de seus conceitos, Dreier (nt. 2), p. 94 e s.

180 Cf. Sieber (nt. 2), in: Sieber/Albrecht (Coord.), p. 78-151.

181 Cf. Biolley/Weyembergh, in: idem (Coord.), Comment évaluer le droit pénal européen, Brüssel, 2006, p. 219 233 (225 e s.).

182 Cf. Sieber (nt. 2), in: Sieber/Albrecht (Coord.), p. 103-109.

183 Cf. supra nt. 2.

184 Cf. Sieber (nt. 2), in: Sieber/Albrecht (Coord.), p. 122.

185 Cf. supra nt. 27 e 30.

186 Cf. supra nt. 27 e 30, assim como, sobre o direito penal comparado como método de pesquisa e objeto de pesquisa, detalhadamente, Sieber (nt. 2), in: Sieber/Albrecht (Coord.), p. 111-125, e sobre os valores fundamentais, especialmente p. 121-123.

187 Cf. sobre as duas primeiras propostas, Sieber (nt. 2), in: Sieber/Albrecht (Coord.), p. 126 e ss.

188 Cf. supra nt. 2.

189 Esses campos de pesquisa correspondem, em parte, também às atividades de pesquisa já existentes no Instituto Max-Planck de Friburgo. A novidade consiste em que a pesquisa nesses campos será concentrada em questionamentos e pontos centrais específicos: os trabalhos agora são reunidos em um programa de pesquisa, que gera as condições para a sinergia necessária, principalmente no tocante ao possível desenvolvimento de uma teoria. Os projetos de pesquisa são relevantes, portanto, freqüentemente, para diversos campos e pontos centrais da pesquisa, por exemplo, quando, por meio de um direito penal comparado com base em diversos ordenamentos jurídicos nacionais, podem-se extrair princípios gerais do direito penal para o direito internacional penal que tenham importância para os limites funcionais do direito penal. Os projetos podem ser beneficiados nesses casos por experiências relevantes em diversos campos de pesquisa e, assim, produzir efeitos e resultados em diferentes campos de pesquisa.

$190 \mathrm{Cf}$. sobre as particularidades do planejamento do projeto, Max-Planck-Institut für ausländisches und internationales Strafrecht (Coord.), Forschungsbericht 2004-2005, 2006, p. 40 e ss.

191 Os recursos do grupo de pesquisa de direito penal do Instituto Max-Planck de direito penal estrangeiro e internacional de Friburgo, no momento da sucessão da diretoria no fim do ano de 2003, ainda estavam vinculados, em grande parte, à finalização de projetos iniciados anteriormente, que - em parte - há muito tempo foram começados e, por isso, precisavam ser terminados com prioridade. Sobre os projetos mais antigos que foram terminados e aqueles que ainda estão em andamento, cf. Max-Planck-Institut für ausländisches und internationales Strafrecht (Coord.) (nt. 190), p. 20,22 e s.

192 São aqui citadas as respectivas exposições, já publicadas. Cf. Sieber (nt. 2), in: Sieber/Albrecht (Coord.), p. $131-151$

193 Sobre a relação entre direito comparado e direito estrangeiro, cf. Jung, JuS 1998, p. 1-7 (2); Rheinstein, Einführung in die Rechtsvergleichung, 2. ed., 1987, p. 22-25, 27-28.

194 Sobre as relevantes possibilidades e limites da informática do direito, cf. Sieber, JURA 1993, p. 561-571 $(565-567)$

195 Roxin, Die Strafrechtswissenschaft vor den Aufgaben der Zukunft, in: Eser/Hassemer/Burkhardt (Coord.), Die deutsche Strafrechtswissenschaft vor der Jahrtausendwende, 2000, p. 369-395 (381 e s.). 
196 Cf. Von Liszt, Zur Einführung, Rückblick und Zukunftspläne, Internationale Kriminalistische Vereinigung, Die Strafgesetzgebung der Gegenwart in rechtsvergleichender Darstellung, v. 1: Das Strafrecht der Staaten Europas, 1894, p. XX e s., XXV. Ver também supra nt. 173.

197 Cf., sobre esse projeto, Sieber (nt. 2), in: Sieber/Albrecht (Coord.), p. 131-151; Max-Planck-Institut für ausländisches und internationales Strafrecht (Coord.) (nt. 190), p. 42-51.

198 Esses projetos englobam, por exemplo, os fatores, agentes e processos da harmonização jurídica, das diferenças fundamentais entre o direito islâmico e o direito ocidenal, assim como o novo processo de controle de crimes pequenos e de massa na Itália. Cf. sobre o atual campo de pesquisa do direito penal comparado, assim como do direito estrangeiro, Max-Planck-Institut für ausländisches und internationales Strafrecht (Coord.) (nt. 190), p. 40-67.

199 Cf. Sieber (nt. 2), in: Sieber/Albrecht (Coord.), p. 78-151.

200 Sobre o desenvolvimento do direito penal na Europa, cf. Hecker, Europäisches Strafrecht, 2005; Satzger, Europäisierung des Strafrechts, Eine Untersuchung zum Einfluss des Europäischen Gemeinschaftsrechts auf das deutsche Strafrecht, 2001; Sicurella, Diritto Penale e competenze dell'Unione Europea, 2005; e as palestras da Dresdener Strafrechtslehrertagung, ZStW 116 (2004), p. 275-474. Ver também Sieber, ZStW 103 (1991), p. 957-979 (963 e ss.).

201 Cf. sobre a determinação dos diversos modelos, supra 2.1.2.b. e 3.a.

202 Sobre os diversos projetos de pesquisa do instituto no campo do direito penal europeu, cf. Max-PlanckInstitut für ausländisches und internationales Strafrecht (Coord.) (nt. 190), p. 70-81.

203 Resumidamente, sobre o desenvolvimento do direito internacional penal, cf. Cassese, International Criminal Law, Oxford et al., 2003; Werle (nt. 23), especialmente, p. 1-28.

204 Cf. o volume final de Kreicker, Nationale Strafverfolgung völkerrechtlicher Verbrechen, 2006, assim como os seis volumes de mesmo nome publicados anteriormente por Eser/Kreicker ou Eser/Sieber/Kreicker, com os relatórios nacionais correpondentes.

205 Cf. Sieber/Koch/Simon, Strafbare Mitwirkung von Führungspersonen in Straftätergruppen und Netzwerken: Eine rechtsvergleichende Analyse, in: Max-Planck-Gesellschaft (Coord.), Jahrbuch der Max-PlanckGesellschaft 2006 (auf CD-ROM).

206 Cf. Sieber (Coord.), The Punishment of Serious Crimes: a comparative analysis of sentencing law and practice, 2 v., 2004 .

207 Sobre o atual campo de pesquisa do direito internacional penal, cf. Max-Planck-Institut für ausländisches und internationales Strafrecht (Coord.) (nt. 190), p. 84-98.

208 Cf. Sieber, Computerkriminalität und Strafrecht, 2. ed., 1980; idem, The International Handbook on Computer Crime, Chichester, 1986; idem, Strafrecht und Strafprozessrecht, in: Hoeren/Sieber (Coord.), Handbuch Multimedia-Recht, 1999, Teil 19; idem, The threat of cybercrime, in: Council of Europe (Coord.), Organised crime in Europe: The threat of cybercrime, Situation report 2004, chapter 3, Strasbourg 2005, p. 81-218.

209 Cf. Sieber, The International Emergence of Criminal Information Law, 1992; idem, NJW 1989, p. 2569-2580; idem, The Emergence of Information Law, in: Lederman/Shapira (Coord.) (nt. 81), p. 1-29.

210 Cf. sobre os diversos projetos de pesquisa do instituto no campo do direito da internet, Max-Planck-Institut für ausländisches und internationales Strafrecht (Coord.) (nt. 190), p. 102-119.

211 Cf., resumidamente, Max-Planck-Institut für ausländisches und internationales Strafrecht (Coord.) (nt. 190), p. 170-189. Para um olhar crítico do potencial da criminologia, cf. Lüderssen, StV 2004, 97-101 (101); para uma abordagem da criminologia sobre o Cybercrime cf. Moitra, European Journal of Crime, Criminal Law and Criminal Justice 2005, p. 435-464. 
212 Cf. Dahs/Müssing e Eser/Koch, in: Deutsche Forschungsgemeinschaft (Coord.), Forschung mit humanen embryonalen Stammzellen, 2003, p. 1-35 e 37-78; Hetz, Schutzwürdigkeit menschlicher Klone?, 2005; Koch, Erzeugung und Verwendung, therapeutischer Klone' aus rechtlicher Sicht, in: Dabrock/Ried (Coord.), Therapeutisches Klonen als Herausforderung für die Statusbestimmung des menschlichen Embryos, 2005, p. 183-207.

213 Sobre doping cf., além da observação na nt. 149, os artigos em Röhricht/Vieweg (Coord.), Doping-Forum, Aktuelle rechtliche und medizinische Aspekte, 2000; Prokop, Die Grenzen der Dopingverbote, 2000. Sobre os novos desenvolvimentos do direito em relação à eutanásia, nos países citados, ver Schreiber, in: Rogall (Coord.), Festschrift für Rudolphi, 2004, p. 543-552. Sobre o teste de medicamentos, cf. Hägele, Arzneimittelprüfung am Menschen, Ein strafrechtlicher Vergleich aus deutscher, österreichischer, schweizerischer und internationaler Sicht, 2004. Sobre os codes of conduct cf. supra nt. 143.

214 Cf. Eser, Perspektiven des Medizin(straf)rechts, in: Frisch (Coord.), Gegenwartsfragen des Medizinstrafrechts, 2006, p. 9-31.

215 Cf. supra nt. 49.

216 Cf. Eser/Koch/Seith (Coord.), Internationale Perspektiven zu Status und Schutz des extrakorporalen Embryos, Baden-Baden, 2007, assim como, sobre os atuais projetos de pesquisa do instituto na área do direito médico, MaxPlanck-Institut für ausländisches und internationales Strafrecht (Coord.) (nt. 190), p. 122-126.

$217 \mathrm{Cf}$., sobre os diversos projetos de pesquisa do instituto no campo dos limites do direito penal, Max-PlanckInstitut für ausländisches und internationales Strafrecht (Coord.) (nt. 191), p. 130-141. Sobre a sugstão de uma iniciativa de pesquisa comum de diversos institutos Max-Planck no campo da pesquisa do terrorismo, cf. Max-PlanckGesellschaft, Terrorismus, Krieg, politische Gewalt, Forschungsperspektiven der Max-Planck-Gesellschaft 2005, 2005, p. 113-114.

218 Com questionamentos especiais sobre os limites funcionais do direito penal, um projeto de tese, iniciado em 2005, trata do novo processo penal para o combate da criminalidade organizada na França, assim como um projeto de tese iniciado em 2006, sobre o combate do terrorismo na Inglaterra. Um outro projeto de tese trata do dever de colaboração de particulares na investigação penal. Uma tese sobre o uso de programas de Compliance como alternativa para evitar a criminalidade empresarial complementa as análises correspondentes sobre medidas alternativas no campo do Cybercrime e do abuso no âmbito das life sciences. Cf. Max-Planck-Institut für ausländisches und internationales Strafrecht (Coord.) (nt. 190), p. 130-141.

219 Cf. sobre a criação da International Max-Planck Research School e seu especial programa de bolsas, disponível em: <http://www.mpg.de/instituteProjekteEinrichtungen/schoolauswahl/criminalLaw/index.html>, Acesso em: 18 dez. 2006.

220 Cf. os artigos em Albrecht/Sieber (Coord.) (nt. 2).

221 Cf. Jescheck, Entwicklung, Aufgaben und Methoden der Strafrechtsvergleichung, 1955.

\section{REFERÊNCIAS BIBLIOGRÁFICAS}

ACKERMAN, Bruce. The Emergency Constitution. Yale Law Journal 113, 2003-2004, p. 1029-1091. ALBRECHT, Hans-Jörg. Rechtstatsachenforschung zum Strafverfahren: : empirische Untersuchungen zu Fragestellungen des Strafverfahrens zwischen 1990 und 2003. Munique: Luchterhand, 2005.

ALEXY, Robert. Theorie der juristischen Argumentation: die Theorie des rationalen Diskurses als Theorie der juristischen Begründung. 2. ed. Frankfurt am Main: Suhrkamp, 1991.

ARSOVSKA, Jana. Understanding a 'Culture of Violence and Crime': the Kanun of Lek Dukagini and the Rise of the Albanian Sexual-Slavery Rackets. In: European Journal of Crime, Criminal Law and Criminal Justice, Vol. 14, 2006, p. 161-184. 
BÄR, Wolfgang. Der Zugriff auf Computerdaten im Strafverfahren. Colônia: Heymann, 1992.

BECK, Wolfgang. Unrechtsbegründung und Vorfeldkriminalisierung. Berlim: Duncker \& Humblot, 1992.

BECK, Ulrich. World Risk Society. Cambridge: Polity Press; Malden: Blackwell, 1999

Das Schweigen der Wörter, Über Terror und Krieg. Frankfurt/Main: Suhrkamp, 2002.

; HOLZER. Wie global ist die Weltrisikogesellschaft? In: BECK, Ulrich; LAU, Christoph (Coord.).

Entgrenzung und Entscheidung: Was ist neu an der Theorie reflexiver Modernisierung? Frankfurt am Main:

Suhrkamp, 2004.

; LAU, Christoph. Second modernity as a research agenda: theoretical and empirical explorations in the

'meta-change' of modern society. In: The British Journal of Sociology, Vol. 56, 2005, p. 525-557.

BELLINGER. Fifth Anniversary of September 11 th Attacks, Remarks. Disponível em:

http://www.state.gov/s/1/rls/73082 htm. Acesso em: 18 dez. 2006.

BERNHARDT. In: SIMMA, Bruno et al. (Coord.). The Charter of the United Nations: a commentary. 2. ed.

Oxford: Oxford University Press, 2002, v. 2.

BIOLLEY, Serge de; WEYEMBERGH, Anne (Coord.). Comment évaluer le droit pénal européen?. Bruxelas: Ed. de l'Universite de Bruxelles, 2006.

BODY-GENDROT, Sophie. Deconstructing Youth Violence in French Cities. European Journal of Crime, Criminal

Law and Criminal Justice, Vol. 13, 2005, p. 4-26.

BONB, Wolfgang. Vom Risiko:Unsicherheit und Ungewißheit in der Moderne. Hamburg: Hamburger Edition 1995.

BREYER, Patrick. Die systematische Aufzeichnung und Vorhaltung von Telekommunikations-Verkehrsdaten für staatliche

Zwecke in Deutschland (Vorratsspeicherung, traffic data retention). Berlim: Rhombos-Verl., 2005.

BRONKHORST, Suzette; EISSENS, Ronald (Coord.). Hate on the Net: virtual nursery for in real life crime,

2004. Disponível em: http://www.jugendschutz.net/pdf/osce_paris.pdf. Acesso em: 18 dez. 2006.

BURNHAM, William. Introduction to the Law and Legal System of the United States. 3. ed. St. Paul: West

Group, 2002.

BWERLE, Gerhard; JESSBERGER, Florian. Völkerstrafrecht. Tübingen: Mohr Siebeck, 2003.

CARTIER, Marie-Élisabeth (Coord.). Le mandat d'arrêt européen. Bruxelas: Bruylant, 2005.

CHESNEY, Robert M. The Sleeper Scenario: Terrorism-Support Laws and the Demands of Prevention. Harvard Journal of Legislation 42, 2005, p. 1-89.

CORNILS, Karim; GREVE, Vagn. Denmark on the Road to Organized Crime. In: FIJNAUT, Cyrille; PAOLI, Letizia (Coord.). Organised Crime in Europe, Patterns and Control Policies in the European Union and Beyond.

Dordrecht; Norwell: Springer, 2004.

CASSESE, Antonio. International Criminal Law. Oxford: Oxford University Press, 2003.

DAHS; MÜSSING; ESER; KOCH. In: Deutsche Forschungsgemeinschaft (Coord.). Forschung mit humanen embryonalen Stammzellen: Rechtsgutachten zu den strafrechtlichen Grundlagen und Grenzen der Gewinnung, Verwendung und des Imports sowie der Beteiligung daran durch Veranlassung, Förderung und Beratung. Weinheim: Wiley-VCH, 2003.

DANNER, Allison Marston; MARTINEZ, Jenny S. Guilty Associations: Joint Criminal Enterprise, Command Responsability, and the Development of International Criminal Law. California Law Review, 93, 2005, p. 75-169.

. Global Crime Calls for Global Justice. European Journal of Crime, Criminal Law and Criminal Justice, Vol.

10, 2002, p. 286-293.

DELMAS-MARTY, Meireille. Le relatif et l'universel. Paris: E?ditions du Seuil, 2004.

DE MAILLARD, Jacques; ROCHÉ, Sebastian. Crime and Justice in France. European Journal of Criminology, Vol.

1, No. 1, 2004, p. 111-151.

DI FABIO, Udo. Der Verfassungsstaat in der Weltgesellschaft. Tübingen: Mohr Siebeck, 2001.

DIWELL. In: GRIESBAUM, Rainer et al. (Coord.). Strafrecht und Justizgewährung, Festschrift für Kay Nehm zum 65. Geburtstag. Berlim: BWV, 2006.

DREIER, Ralf. Recht - Moral - Ideologie: Studien zur Rechtstheorie. Frankfurt am Main: Suhrkamp, 1981.

DUBBER. In: REIMANN, Mathias; ZIMMERMANN, Reinhard (Coord.). The Oxford Handbook of Comparative Law. Oxford: Oxford University Press, 2006

DUBET. In: VON TROTHA, Trutz (Coord.). Soziologie der Gewalt. Oplabaden: Westdeutscher Verlag, 1997.

ESER. Perspektiven des Medizin(straf)rechts. In: FRISCH, Wolfgang (Coord.). Gegenwartsfragen des Medizinstrafrechts. Baden-Baden: Nomos, 2006.

__; KOCH; SEITH (Coord.). Internationale Perspektiven zu Status und Schutz des extrakorporalen Embryos: rechtliche Regelungen und Stand der Debatte im Ausland. Baden-Baden: Nomos, 2007.

FISCHER-LESCANO, Andreas; TEUBNER, Gunther. Regime-Kollisionen: Zur Fragmentierung des globalen Rechts. Frankfurt am Main: Suhrkamp, 2006.

FLETSCHER, George P. The Grammar of Criminal Law. Oxford: Oxford University Press, 2007. 
GEIB, Robin. "Failed States": die normative Erfassung gescheiterter Staaten. Berlim: Duncker \& Humblot, 2005. GERBER, Jurg; KILLIAS, Martin. The Transnationalization of Historically Local Crime: Auto Theft in Western Europe and Russia Markets. European Journal of Crime, Criminal Law and Criminal Justice, Vol. 11, 2003, p. 215-226.

GRANDE. In: BECK, Ulrich; BONB, Wolfgang (Coord.). Die Modernisierung der Moderne. 2. ed. Frankfurt am Main: Suhrkamp, 2001.

GREVE, Vagn. Sheep or Wolves. European Journal of Crime, Criminal Law and Criminal Justice, 2005, Vol. 13, p. 515-532.

GROS, Jean-Germain. Trouble in Paradise. Crime and Collapsed States in the Age of Globalization. British Journal of Criminology 43, 2003, p. 63-80.

GROSS, Emanuel. The Struggle of Democracy Against Terrorism: lessons from the United States, the United Kingdom, and Israel. Charlottesville: University of Virginia Press, 2006.

GUILLEMIN, Jeanne. Biological Weapons - From the Invention of State Sponsored Programs to Contemporary Bioterrorism. Nova Iorque: Columbia University Press, 2006.

HÄBERLE, Peter. Europäische Rechtskultur. Baden-Baden: Nomos 1994.

HARDING, Christopher. Forging the European Cartel Offence: The Supranational Regulation of Business Conspiracy. European Journal of Crime, Criminal Law and Criminal Justice, Vol. 12, 2004, p. 275-300.

HASSEMER, Winfried. Strafrechtsdogmatik und Kriminalpolitik. Reinbek: Rowohlt, 1974.

. In: GRIESBAUM et al. (Coord.). Strafrecht und Justizgewährung, Festschrift für Kay Nehm zum 65.

Geburtstag. Berlim: BWV, 2006.

HECKER, Bernd. Europäisches Strafrecht. Berlim: Springer, 2005.

HEFENDEHL, Roland. Kollektive Rechtsgüter im Strafrecht. Colônia: Heymann, 2002.

HÄGELE, Ralf H.W. Arzneimittelprüfung am Menschen: ein strafrechtlicher Vergleich aus deutscher, österreichischer, schweizerischer und internationaler Sicht. Baden-Baden: Nomos, 2004.

HEINE. In: PIETH, Mark; SEELMANN, Kurt (Coord.). Prozessuales Denken als Innovationsanreiz für das materielle Strafrecht: Kolloquium zum 70. Geburtstag von Detlef Krauss. Basel: Helbing \& Lichtenhahn, 2006.

HERZOG, Felix; MÜLLHAUSEN, Dieter. Geldwäschebekämpfung und Gewinnabschöpfung: Handbuch der straf- und wirtschaftsrechtlichen Regelungen. Munique: Beck, 2006

HETZ, Silke. Schutzwürdigkeit menschlicher Klone?: eine interdisziplinäre Studie aus mendizinrechtlicher Sicht. Baden-Baden: Nomos, 2005.

HOOKER, Charles H. The Past as Prologue: Schneiderman v. United States and Contemporary Questions of Citizenship and Denationalization. In: Emory International Law Review 19, 2005, p. 305-381.

HOWELL, Beryl A. Seven Weeks: The Making of the USA Patriot Act. GeorgeWashington Law Review 72, 2003 2004, p. 1145-1207.

INSTITUTO NACIONAL de Ciencias Penales/Max-Planck-Institut für ausländisches und internationales Strafrecht (Coord.). Hacia la unificación del derecho penal, Logros y desafíos de la armonización y homologación en México y el mundo, México, 2006.

JAKOBS, Günther. Norm, Person, Gesellschaft: Vorüberlegungen zu einer Rechtsphilosophie. Berlim: Duncker \& Humblot, 1997.

JESCHECK, Hans Heinrich. Entwicklung, Aufgaben und Methoden der Strafrechtsvergleichung. Tübingen: J.C.B.

Mohr, 1955.

JESCHECK. Strafrecht und Kriminologie unter einem Dach. In: ALBRECHT, Hans-Jörg; KAISER, Günther. Kriminologie: ein Lehrbuch. 3. ed. Heidelberg: Müller, 1996.

KATYAL, Neal Kumar. Conspiracy Theory. Yale Law Journal, Vol. 112, No. 6, 2003, p. 1307-1398.

Hamdan v. Rumsfeld: The Legal Academy Goes to Practice. In: Harvard Law Review 120, 2006, p. 65-123.

KOHLER, Josef. Internationales Strafrecht. Stuttgart: F. Enke, 1917.

KOCH. In: RÖHRICHT, Volker; VIEWEG, Klaus (Coord.). Doping-Forum. Stuttgart: Richard Boorberg Verlag, 2000.

. In: ARNOLD, Jörg (Coord.). Menschengerechtes Strafrecht: Festschrift für Albin Eser zum 70. Geburtstag. Munique: C.H. Beck, 2005

. Erzeugung und Verwendung, therapeutischer Klone' aus rechtlicher Sicht. In: DABROCK, Peter; RIED,

Jens (Coord.). Therapeutisches Klonen als Herausforderung für die Statusbestimmung des menschlichen Embryos.

Paderborn: Mentis, 2005.

KOH, Harold Hongju. The Case against Military Comissions. American Journal of International Law, Vol. 96, No. 2, 2002, p. 337-344.

KREICKER, Helmut. Nationale Strafverfolgung völkerrechtlicher Verbrechen Bd. 7. Völkerstrafrecht im

Ländervergleich. Berlim: Duncker und Humblot, 2006. 
KÜHNE, Hans Heine. Strafprozessrecht: eine systematische Darstellung des deutschen und europäischen Strafverfahrensrechts. 6. ed. Heidelberg: C.F. Müller, 2003.

KÜRZINGER, Josef; KAISER, Günther (Coord.). Kriminologie in Europa, europäische Kriminologie?: Kolloquium aus Anlass des 65. Geburtstags von Prof Dr. Dr. h.c. mult. Günther Kaiser, 14. Januar 1994. Freiburg: MaxPlanck-Institut für Ausländisches und Internationales Strafrecht, 1994.

LIMBACH, Jutta. Die Demokratie und ihre Bürger: Aufbruch zu einer neuen politischen Kultur. Munique: Beck, 2003. MASCIANDARO, Donato (Coord.). Global financial crime: terrorism, money laundering and offshore centres. Aldershot; Burlington: Ashgate, 2004.

MANSELL, Robin;COLLINS, Brian S. (Coord.) Trust and crime in information societies. Cheltenham; Northampton: Edward Elgar, 2005.

MEIERHENRICH, Jens. Analogies at War. In: Journal of Conflict and Security Law 11, 2006, p. 1-40. MEYER, Silk. HRRS. Disponível em: http://www.hrr-strafrecht.de. Acesso em: 18 dez. 2006.

Trafficking in Human Organs in Europe: A Myth or an Actual Threat?. European Journal of Crime,

Criminal Law and Criminal Justice, Vol. 14, 2006, p. 208-229.

MOITRA, Soumyo D. Developing Policies Cybercrime. European Journal of Crime, Criminal Law and Criminal Justice, Vol. 13, 2005, p. 435-464.

NADELMANN, Ethan Avram. Cops Across Borders: the internationalization of U.S. criminal law enforcemenota University Park: Pennsylvania State University Press, 1993.

NASIRI, Omar. Mein Leben bei Al Qaida. Munique: Deutsch Verl.-Anst, 2006.

NEHM. In: ARNOLD, Jörg (Coord.). Menschengerechtes Strafrecht, Festschrift für Albin Eser zum 70. Geburtstag. Munique: C.H. Beck, 2005.

O’DAY, Alan. Cyberterrorism. Aldershot; Burlington: Ashgate, 2004.

Weapons of mass destruction and terrorism. Aldershot; Burlington: Ashgate, 2004.

O'ROURKE, Kevin H.; WILLIAMSON, Jeffrey G. When did globalisation begin? European Review of Economic History. Vol. 6, 2002, p. 23-50.

O'ROURKE, Kevin H.; WILLIAMSON, Jeffrey G. When did globalisation begin? European Review of Economic History. Vol. 8, 2004, p. 109-117.

OST, François; VAN DE KERCHOVE, Michel. De la pyramide au réseau? Pour une théorie dialectique du droit. Bruxelas: Publications des Facultes universitaires Saint-Louis, 2002.

PRIM, Rolf; TILMANN, Heribert. Grundlagen einer kritisch-rationalen Sozialwissenschaft: Studienbuch zur Wissenschaftstheorie Karl R. Poppers. 8. ed. Wiebelsheim: Quelle \& Meyer, 2000, p. 76-93

PROKOP, Clemens. Die Grenzen der Dopingrerbote. Baden-Baden: Nomos, 2000.

RAMSEY, Michael D. Textualism and War Powers. The University of Chicago Law Review, Vol. 69, No. 4, 2002, p. 1543-1638.

REEMTSMA, Jan Phillip. Folter im Rechtsstaat?. Hamburgo: Hamburger Edition, 2005.

RHEINSTEIN, Max; VON BORRIES, Reimer; NIETHAMMER, Hans-Eckart. Einführung in die Rechtsvergleichung. 2. ed. Munique: Beck, 1987.

RODLEY, Nigel S. The Prohibition of Torture: Absolute Means Absolute. In: KALECK, Wolfgang (Coord.). International Prosecution of Human Rights Crimes. Berlim; Nova Iorque: Springer, 2007.

RÖHRICHT, Volker; VIEWEG, Klaus (Coord.). Doping-Forum, Aktuelle rechtliche und medizinische Aspekte. Stuttgart: Richard Boorberg Verlag, 2000.

ROXIN, Klaus. In: ESER, Albin; HASSEMER, Winfried; BURKHARDT, Björn (Coord.). Die deutsche

Strafrechtswissenschaft vor der Jahrtausendwende: Rückbesinnung und Ausblick : Dokumentation einer Tagung vom 3. 6. Oktober 1999 in der Berlin-Brandenburgischen Akademie der Wissenschaften. Munique: C. H. Beck, 2000. . In: ARNOLD, Jörg (Coord.). Menschengerechtes Strafrecht, Festschrift für Albin Eser zum 70, Geburtstag. Munique: C.H. Beck, 2005. Beck, 2006. Strafrecht. Allgemeiner Teil Bd. 1: Grundlagen. Der Aufbau der Verbrech enslehre. 4. ed. Munique:

Strafrecht: allgemeiner Teil. 4. ed. Munique: C. H. Beck, 2006.

SATZGER, Helmut. Europäisierung des Strafrechts, Eine Untersuchung zum Einfluss des Europäischen Gemeinschaftsrechts auf das deutsche Strafrecht. Colônia: Heymann, 2001.

SCHALLER, Christian. Private Sicherheits und Militärfirmen in bewaffneten Konflikten: Völkerrechtliche Einsatzbedingungen un Kontrollmöglichkeiten. Berlim: Stiftung Wissenschaft und Politik Deutsches Institut für Internationale Politik und Sicherheit, 2005.

SCHILY. In: Bundeskriminalamt (Coord.). Neue Allianzen gegen Kriminalität und Gewalt: ganzheitlicher Ansatz zur Kriminalitätsbekämpfung - national und international: Vorträge anlässlich der Herbsttagung des Bundeskriminalamtes. Munique: Luchterhand, 2006. 
SCHREIBER. In: ROGALL, Klaus (Coord.). Festschrift für Hans-Joachim Rudolphi zum 70. Geburtstag. Neuwied: Luchterhand; Munique: Wolters-Kluwer, 2004.

SCHROEDER, Friederich-Christian. Die Straftaten gegen das Strafrecht. Berlim; Nora Iorque: De Gruyter, 1985. SCHÜNEMANN. In: LORENZ, Stephan; HELDRICH, Andreas (Coord.). Festschrift für Andreas Heldrich zum 70. Geburtstag. Munique: Beck, 2005.

SEAMON, Richard H.; GARDNER, William Dylan. The Patriot Act and the wall between foreign intelligence and law enforcemenota Harvard Journal of Law and Public Policy 28, 2004-2005, p. 319-463.

SHAMS, Heba M. Legal globalization, money laundering and other cases. London: British Institute of International and Comparative Law, 2004.

SICURELlA, Rosaria. Diritto Penale e competenze dell'Unione Europea: linee guida di un sistema integrato di tutela dei beni giuridici sovrannazionali e dei beni giuridici di interesse comune. Milão: Giuffrè, 2005.

SIEBER, Ulrich. Transnational Enterprises and Criminal Law, in: Tiedemann (Coord.). Multinationale

Unternehmen und Strafrecht: Beitr. zum Problem d. Kriminalität im grenzüberschreitenden Geschäftsverkehr.

Colônia; Munique: Heymann, 1979.

. Computerkriminalität und Strafrecht. 2. ed. Colônia; Berlim, Bonn; Munique: Heymann, 1980.

The International Handbook on Computer Crime. Chichester; Nova Iorque: Wiley, 1986.

. The International Emergence of Criminal Information Law. Colônia: C. Heymanns, 1992.

; BÖGEL, Marion. Logistik der Organisierten Kriminalität: wirtschaftswissenschaftlicher Forschungsansatz

und Pilotstudie zur internationalen Kfz-Verschiebung Wiesbaden: Bundeskriminalamt, 1993. . Auf dem Weg zu einem europäischen Strafrecht. In: DELMAS-MARTY, Meireille (Coord.). Corpus

Juris der strafrechtlichen Regelungen zum Schutz der finanziellen Interessen der Europäischen Union. Colônia:

Heymanns, 1998.

Strafrecht und Strafprozessrecht. In: HOEREN, Thomas; SIEBER, Ulrich (Coord.). Handbuch

Multimedia-Recht: Rechtsfragen des elektronischen Geschaftsverkehrs. Munique: Beck, 1999.

. Verantwortlichkeit im Internet: Technische Kontrollmöglichkeiten und multimediale Regelungen: Zugleich

eine Kommentierung von [Paragraphen] 5 TDG und [Paragraphen] 5 MDStV. Munique: C.H. Beck, 1999.

. Kinderpornographie, Jugendschutz und Providerverantwortlichkeit im Internet: Eine strafrechtsvergleichende

Untersuchung. Bonn: Forum Verlag Godesberg, 1999.

. In: Waltermann, Jens; MACHILL, Marcel; STIFTUNG, Bertelsmann (Coord.). Protecting our children on the

internet - towards a new culture of responsibility. Gütersloh: Bertelsmann Foundation, 2000, p. 319-399 (345-378).

; LEDERMAN, Eliezer; SHAPIRA, Ron (Coord.). Law, Information and Information Technology. The Hague;

New York: Kluwer Law International, 2001.

. In: DUTTGE, Gunnar et al. (Coord.). Gedächtnisschrift für Ellen Schlüchter. Colônia: Heymanns, 2002,

p. 107-116 (114)

(Coord.). The Punishment of Serious Crimes: a comparative analysis of sentencing law and practice, $2 \mathrm{v}$.

Freiburg im Breisgau: Ed. iuscrim, Max-Planck-Instituts für Ausländisches und Internationales Strafrecht, 2004. . The threat of cybercrime. In: Council of Europe (Coord.). Organised crime in Europe: The threat of

cybercrime, Situation report 2004. Strasbourg: Council of Europe Pub., 2005.

. Grenzen des Strafrechts. In: Albrecht/Sieber (Coord.). Perspektiven der strafrechtlichen Forschung,

Amtswechsel am Freiburger Max-Planck-Institut für ausländisches und internationales Strafrecht 2004, 2006.

. Strafrechtsvergleichung im Wandel. In: SIEBER, Ulrich; ALBRECHT, Hans-Jörg (Coord.). Strafrecht

und Kriminologie unter einem Dach: Kolloquium zum 90. Geburtstag von Professor Dr. Dr. h.c. mult. Hans-

Heinrich Jescheck am 10. Januar 2005. Berlim: Duncker \& Humblot, 2006, p. 78-151.

SIESSEGER, Marie E. Conspiracy Theory: The Use of the Conspiracy Doctrine in Times of National Crisis. In:

William and Mary Law Review, 46,2004, p. 1177-1218.

SMARTT, Ursula. Human Trafficking: Simply a European Problem?. In: European Journal of Crime, Criminal Law and Criminal Justice, Vol. 11, 2003, p. 164-177.

SOEK, J. W. The Strict Liability Principle and the Human Rights of Athletes in Doping Cases. The Hague: T.C.M.

Asser Press, 2006.

SOROS, George. Die Krise des globalen Kapitalismus. Berlim: Fest, 1998.

STIGLITZ, Joseph. Die Chancen der Globalisierung. München: Siedler 2006.

STRUENSEE. In: SAMSON, Erich (Coord.). Festschrift für Gerald Grünwald zum siebzigsten Geburtstag. Baden-

Baden: Nomos, 1999.

TAKEI, Carl. Terrorizing Justice: An Argument That Plea Bargains Struck under the Threat of Enemy Combatant Detention Violate the Right to Due Process. In: Boston College Law Review, 47, 2006, p. 581-626.

TEUBNER. In: BRAND, Jürgen; STREMPEL, Dietrel; BLANKENBURG, Erhard (Coord.). Soziologie des Rechts, Festschrift für Erhard Blankenburg zum 60. Geburtstag. Baden-Baden: Nomos 1998. 
THE MANUAL for Military Commissions, 2007. Disponível em: http://www.defenselink.mil/news/commissonsmanual.html. Acesso em: 26 fev. 2007.

TIEDEMANN, Klaus. Tatbestandsfunktionen im Nebenstrafrecht: Untersuchungen zu einem rechtsstaatlichen Tatbestandsbegriff, entwickelt am Problem des Wirtschaftsstrafrechts Tübingen: Mohr, 1969.

TIEDEMANN, Klaus et al. Multinationale Unternehmen und Strafrecht: Beitr. zum Problem d. Kriminalität im grenzüberschreitenden Geschäftsverkehr. Colônia; Bonn: Heymann, 1979.

TILLMANN, R. Global pirates: fraud in the offshore insurance industry. Boston: Northeastern University Press, 2002.

VERVAELE, John A. E. The Anti-Terrorist Legislation in the US: Inter Arma Silent Leges?. In: European Journal of Crime, Criminal Law and Criminal Justice, Vol. 13, 2005a, p. 201-254.

Intersentia, 2005b.

(Coord.). European Evidence Warrant: transnational judicial inquiries in the EU. Antwerpen:

Mercosur and Regional Integration in South America. International Comparative Law Quarterly, Vol. 54, No. 2, 2005c, p. 389-409.

VIEWEG, Klaus; SIEKMANN, Robert C. R. (Ed.). Legal Comparison and the Harmonisation of Doping Rules. Berlim: Duncker \& Humblot, 2007.

VOGEL, Joachim. Juristische Methodik. Berlim; Nova Iorque: De Gruyter, 1998.

; NOROUZI. The European Arrest Warrant, ne bis in idem and the problem of multiple jurisdictions. In:

GUIDICELLE-DELAGE, Geneviève; MANACORDA, Stefano (Coord.). L'intégration pénale indirecte: interactions entre droit pénal et coopération judiciaire au sein de l'Union européenne. Paris: Société de législation comparée, 2005.

VON BOGDANDY, Arnim. Gubernative Rechtssetzung. Tübingen: Mohr, 2000.

VON BUBNOFF, Eckhart. Der Europäische Haftbefehl. Heidelberg: Müller, 2005.

WALTER, Christian et al.(Coord.). Terrorism as a Challenge for National and International Law: Security versus Liberty?. Berlim; Londres; Nova Iorque: Springer, 2004.

WEZEMAN; BROMLEY. In: SIPRIYearbook 2005: armaments, disarmament and international security. Oxford: Oxford University Press, 2005.

WEIMANN, Gabriel. Terror on the Internet: the new arena, the new challenges. Washington: United States Institute of Peace; Bristol: University Presses Marketing, 2006.

WEßLAU, Edda. Vorfeldermittlungen: Probleme der Legalisierung "vorbeugender Verbrechensbekämpfung” aus strafprozeßrechtlicher Sicht. Berlim: Duncker \& Humblot, 1989

WETZELS, Peter; BRETTFELD, Katrin. Auge um Auge, Zahn um Zahn? Migration, Religion und Gewalt junger Menschen: eine empirisch-kriminologische Analyse der Bedeutung persönlicher Religiosität für Gewalterfahrungen, einstellungen und handeln muslimischer junger Menschen im Vergleich zu Jugendlichen anderer religiöser Bekenntnisse. Münster: Lit ., 2003.

WILKITZKI, Peter. The German law on co-operation with the ICC. International Criminal Law Review 2, 2002, p. 195-212.

WOHLERS, Wolfgang. Deliktstypen des Präventionsstrafrechts: Zur Dogmatik "moderner" Gefährdungsdelikte. Berlim: Duncker \& Humblot , 2000

WOLFRUM, Rüdiger. In: DAHM, Georg; DELBRÜCK, Jost; WOLFRUM, Rüdiger. Völkerrecht. 2. ed.

\section{Ulrich Sieber}

Max-Planck

- Instituto de Direito Penal Estrangeiro e Internacional Günterstalstraße, 73 - 79100 Freiburg i. Br., Alemanha u.sieberlampicc.de
DiRETOR do MAX PLANCK INSTITUTE For Foreign AND international Criminal Law em Freiburg, Alemanha 